\title{
The Cost of Antitrust Law to Malaysia's Financial Services Sector
}

\author{
Bryane Michael (University of Hong Kong) \\ Mark Williams (University of Melbourne) \\ Susila Munisamy (University of Malaya)
}

\begin{abstract}
Judging by only economic incentives, Malaysian financial institutions (particularly banks) should completely ignore the Competition Act. The data show that Malaysian banks probably benefit from anticompetitive behaviour. Political and family connections likely facilitate such behaviour. Given that the Malaysian Competition Commission will likely lack the resources to investigate and sanction anti-competitive behaviour in Malaysia's banking industry - the banks' best response to the Act probably consists of ignoring it. Maximum fines of 10 million ringgit and revenue-tied penalties of only $10 \%$ of worldwide revenue mean that banks still have strong incentives to engage in anticompetitive behaviour and to pay any low fine that might be levied. The best compliance programme for banks in Malaysia likely consists of actions that avoid detection rather than detecting and preventing anticompetitive behaviour. Private rights of action are unlikely to provide any stronger economic incentives for Malaysian banks to adopt strong antitrust compliance programmes and internal audit programmes. By staying the course, Malaysian banks can continue to earn about 15 billion ringgits (approximately US\$4.6 billion in anticompetitive rents).
\end{abstract}

Keywords: antitrust compliance, internal audit, Malaysia JEL Codes: D41, L41, L44

Disclaimer: The views expressed in this paper belong to the authors alone. The paper aims to raise important economic issues in an engaging way, encourage debate and contribute to the marketplace of ideas. Naturally, nothing in this paper should be taken as encouraging legal disobedience. 


\section{Contents}

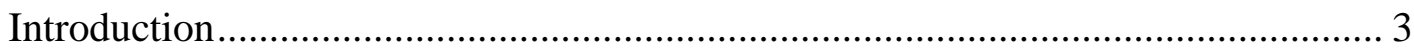

International Cases Suggest Lax Antitrust Enforcement Likely in Malaysia............ 4 Anti-Competitive Behaviour is Probably Higher than in Many Other Countries ... 10 Anti-Competitive Behaviour Probably Stems from Collusion within Government

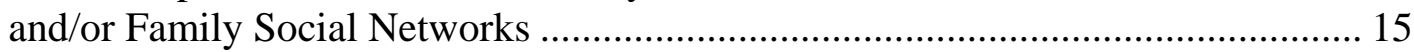
Malaysian Competition Commission Scrutiny Probably Will Not Have a Significant Effect 21

Detecting Anticompetitive Behaviour and Creating Antitrust Compliance

Campaigns in Malaysia’s Financial Services 29

The Effect on the Competition Act on Anticompetitive Behaviour in Malaysian

Banking 40

The Cost of Antitrust Internal Audit in the Malaysian Financial Service Sector .... 50

Conclusion 64

Appendix I: Draft Memorandum of Understanding between the Bank Negara and the Competition Commission 66 


\section{The Cost of Antitrust Law to Malaysia's Financial Services Sector Bryane Michael (University of Hong Kong), Mark Williams (University of Melbourne) and Susila Munisamy (University of Malaya)}

\section{Introduction}

Recent antitrust scandals involving financial institutions have drawn competition agencies' attention almost everywhere. Recent investigations into banks’ manipulation of inter-bank rate fixing, blocking derivatives exchanges from entering the credit default swap business and other scandals have attracted competition authorities' attention. So far the Malaysian Competition Commission has paid little attention to Malaysia's financial services sector. ${ }^{1} Y$ et, the fines and public kudos competition commissions attain as a result of financial services probes makes the Malaysian Competition Commission’s attention to this sector almost unavoidable. ${ }^{2}$ Investigations alone could cost Malaysian banks \$3 billion - whether they have engaged in wrong-doing or not. ${ }^{3}$ How can financial services providers in Malaysia ensure their agents do not engage in anti-competitive behaviour which could make them the target of domestic or foreign anti-trust investigations or more provocatively, should they even bother?

We find that perverse incentives provided by the Competition Act mean that Malaysian financial services firms (and particularly its banks) will not - and should not - bear the cost of antitrust compliance programmes in the near-term. Indeed, problems with maximum fines and capped revenue-based penalties of $10 \%$ of world-wide revenue make it so that Malaysian banks have economic incentives to behave anti-competitively, even though this would constitute a prima facie infringement of the Competition Act. Consequently, such behaviour would be concealed from the Competition Commission and this might therefore involve attempts to frustrate any investigation in respect of such collusion.

The first section of this paper reviews the general risk areas susceptible to anticompetitive behaviour by financial institutions. ${ }^{4}$ The second section uses data to assess the extent to which these risk areas likely affect Malaysian banks. The third section looks at the likely effect of Malaysian Competition Commission scrutiny of

\footnotetext{
${ }^{1}$ Our search of the Malaysian Competition Commission’s intended work on financial services includes a review of the Commission's website and review of global media (using Google and Factiva).

${ }^{2}$ The $\$ 2.3 b$ in fines from the LIBOR case, with follow-on suits being unavoidable, almost certainly represent the tip of the iceberg.

${ }^{3}$ We refer to econometric studies later in this paper showing that the effect of a competition commission's investigation can reduce firm market value by up to $5 \%$. Our estimate comes from using a market capitalisation of Malaysia’s largest banks of roughly $\$ 80$ billion (in 2013) and a loss rate of $4 \%$.

${ }^{4}$ For the purposes of this paper, we refer to financial institutions primarily in the context of banks and (to a much lesser extent) broker-dealers. We do not have space to discuss insurance companies, investment companies, retirement funds, non-bank financial institutions (like trade credit organisations) and others. In any case, such a discussion would complicate our analysis without adding any new insights into our question.
} 
Malaysia's financial institutions. If the Commission cannot (or does not wish) to monitor local financial institutions, then internal controls aimed at reducing the risk of an administrative investigation become relatively useless. The fourth section looks at some of the ways internal auditors can spot anticompetitive behaviour in Malaysia's banks - and suggests activities internal auditors can propose to management based on data. The fifth section looks at the effect of Malaysia's competition law on banks' incentives to engage in anticompetitive behaviour (and to adopt internal controls against such behaviour). The sixth section describes the likely cost of antitrust compliance programmes in such a context. The final section concludes.

\section{International Cases Suggest Lax Antitrust Enforcement Likely in Malaysia}

Concentration (and close relationships) provides for the market power that allows for anti-competitive behaviour by financial service providers in almost all countries. ${ }^{5}$ A number of measures serve as indicators for discovering the extent to which financial service providers have potentially used illegal means to create market power and/or exercise such market power illegally. ${ }^{6}$ Figure 1 provides some of the classical indicators that regulators, compliance officers and competitive intelligence analysts use in assessing potential risks for anti-competitive behaviour in specific markets (like financial markets). ${ }^{7}$ Such indicators also provide an insight into the extent to which anti-competitive behaviour occurs in developing countries' financial services sector such as Malaysia’s. ${ }^{8}$ Other factors - like deregulation, financial market innovation, improvements in investing capabilities, and so forth -may also explain factors like those in the figure. Nevertheless, the issues highlighted in the figure help regulators, financial services firms and their

\footnotetext{
${ }^{5}$ We obviously do not have space to describe the factors that contribute to the illegal formation and use of market power in the financial services sector. For an excellent primer on the issues (with a focus on the EU), see Andrea Lista, EU COMPETITION LAW AND THE FinANCIAL SERVICES SECTOR, 2013.

${ }^{6}$ Studies of concentration may seem passé. Economists have been discussing the role of concentration in the illegal exercise of market power from the 1970s onward, with limited success. Yet, recent events show that even such a simple measure continues to provide a warning indicator for anti-competitive behaviour among market participants. Durden for example provides a popularmedia discussion of how concentration studies of the credit default swap market would have tipped off regulators and market participants about potential abuses in that market. See Tyler Durden, The CDS Market And Anti-Trust Considerations, Zero Hedge, 22 January, 2012, available online. ${ }^{7}$ See Alton Gilbert and Adam Zaretsky, Banking Antitrust: Are the Assumptions Still Valid? FED. REV. BANK OF ST. LOUIS REV., 2003, available online.

Also Christenfeld and Goodstein provide an overview of some of the major areas. See also Alan Christenfeld and Barbara Goodstein, Analysing Antitrust Issues in Lending, 249 NYLJ 108, 2013, available online. See also Mark Powell and Katarzyna Czapracka, Recent EU Antitrust Investigations into Financial Services - What Is the Scope for Antitrust Intervention? CPI Antitrust Chronicle, available online.

${ }^{8}$ Antitrust professionals and competition economists continue to assess whether the old measures still point to antitrust abuses. As the Absolt Vodka ads prosthelytize, one always goes back to the basics. See John Walter and Patricia Wescott, Antitrust Analysis in Banking: Goals, Methods, and Justifications in a Changed Environment, 94 ECON. QUART. 1, 2008, available online.
} 
competitors focus their first attempt at uncovering illegal anticompetitive behaviour in such firms. ${ }^{9}$ Malaysian financial services providers may need to worry about concentration, market share and co-operative agreements with other organisations even if firms have achieved these positions legally. ${ }^{10}$

\section{Figure 1: What to Watch When Assessing Potential Anticompetitive Behaviour (or Concentration Breeds Market Power)}

Indicator
Market share* in
lending markets

\section{Market share of} deposits

\section{Profit rates}

(NIM)**

Market share in market making and/or securities sales Lending/deposit terms Access to banking

Ownership and/or control

\section{Description}

Banks with large shares of lending in a particular market may have the power to set lending rates, extract rents from fees associated with lending (like high document processing fees), and so forth. Banks holding a high proportion of a market's deposits may have "done something" to obtain those deposits. ${ }^{* * *}$

High profits remain the single-number, headline indicator for anticompetitive behaviour.

Dealing with the securities (rather than banking) part of the financial services industry, unusually high fees or high mark-ups point to the use of market power or collusion among broker-dealers.

High lending rates suggest monopoly power over money in a market and low deposit rates may suggest monopsonistic power to "buy" money.

Reduced quantity of banking and securities services points to imperfect competition (and thus potential anticompetitive behaviour). The "crime” part of anticompetitive behaviour stems from lower quantities and higher prices paid by society.

Extensive ownership of financial institutions by the government, particular families or institutional investors can result in collusive practices across organisations.

* "Market share” represents a notoriously difficult concept to define clearly. Such markets may be local or national and may cover specific products (like auto loans) or lending more generally. In a federal context like Malaysia's, the definition of the relevant market becomes so much more the difficult.

** NIM refers to net interest margins.

*** This article's target audience represents policymakers and educated non-specialists in antitrust. As such, we avoid excessively technical descriptions of anticompetitive behaviour. We provide plenty of references in footnotes to guide readers interested in more details.

Source: based on Gilbert and Zaretsky (2003).

Specific anti-competitive practices have appeared in foreign (non-Malaysian) jurisdictions' financial service sectors that serve as potential examples of activity

\footnotetext{
${ }^{9}$ As we describe later, Malaysia and other countries do not all criminalise all anticompetitive behaviour. Not all market power stems from illegal activity. While not all market power or cooperation between market actors represents illegal anticompetitive behaviour, all anticompetitive behaviour must emerge as the result of market power or such co-operation. As such, screening for market power and co-operation between market actors serves as a useful scan for such illegal anticompetitive behaviour.

${ }^{10}$ We show later in this paper that they do not need to worry about antitrust enforcement in the short-term. However, high market shares, high fees and decisions about rates and other service provision which follows competitors too closely may attract unwanted Competition Commission attention in the longer term.
} 
that may occur in Malaysia. Figure 2 provides an overview of some of the recent cases involving such anti-competitive behaviour. ${ }^{11}$ Many of these cases involve collusion in respect of complex products, rather than run-of-the-mill collusion over lending rates or quantitative restrictions. ${ }^{12}$ While no recent cases of anticompetitive behaviour involving retail banking have come to international media attention, Malaysian financial institutions can still learn from other countries' efforts to identify and mitigate risks in respect of the retail banking sector generally. ${ }^{13}$ These cases may attract Competition Commission attention to similar problems in the Malaysian financial services sector.

\section{Figure 2: Recent Areas of Antitrust Enforcement and Relevance to Malaysia}

\begin{tabular}{|c|c|c|}
\hline Area & Link* & Relevance to Malaysian financial institutions \\
\hline $\begin{array}{l}\text { Credit card providers } \\
\text { offering discounts (or } \\
\text { not) }\end{array}$ & $\stackrel{*}{-}$ & $\begin{array}{l}\text { The Commission** may target Malaysian credit card providers in } \\
\text { "me too" investigations and enforcement actions. }\end{array}$ \\
\hline $\begin{array}{l}\text { Making separate } \\
\text { rules for banks and } \\
\text { non-bank lenders }\end{array}$ & $\underline{*}$ & $\begin{array}{l}\text { Islamic and other banks trying to use differences in legal status } \\
\text { may face challenges on grounds that different treatment by Bank } \\
\text { Negara and Securities Commission may represent unfair } \\
\text { (discriminatory) regulation. }\end{array}$ \\
\hline $\begin{array}{l}\text { Agreements on } \\
\text { restrictions of lending } \\
\text { to SMEs }\end{array}$ & * & $\begin{array}{l}\text { Malaysian small and medium enterprises may challenge loan } \\
\text { refusals on competition grounds (and banks may need to consider } \\
\text { other factors besides risk). }\end{array}$ \\
\hline $\begin{array}{l}\text { Linking data sellers } \\
\text { to exchanges or } \\
\text { providers }\end{array}$ & $\stackrel{*}{-}$ & $\begin{array}{l}\text { Malaysian financial services companies may not be able to offer } \\
\text { data to close business partners anymore. Providing data generated } \\
\text { through trades may require investment in data-sharing } \\
\text { technologies. }\end{array}$ \\
\hline $\begin{array}{l}\text { Limits on availability } \\
\text { of loans and/or } \\
\text { foreign exchange }\end{array}$ & * & $\begin{array}{l}\text { Malaysian interest rates are higher than other countries’. Banks } \\
\text { will need to ensure mark-ups on foreign exchange are not too } \\
\text { high and such foreign exchange is available to all market } \\
\text { actors.*** }\end{array}$ \\
\hline LIBOR fixing & $\underline{*}$ & $\begin{array}{l}\text { KLIBOR less prone to manipulation, but banks may play with the } \\
\text { host of other lending rates. }\end{array}$ \\
\hline CDS collusion & $\underline{*}$ & $\begin{array}{l}\text { Smaller size of Malaysia's derivatives markets make them ripe } \\
\text { for non-competitive clearing methods in order to create markets } \\
\text { in this early stage of their development. }\end{array}$ \\
\hline $\begin{array}{l}\text { Municipal bond bid- } \\
\text { rigging }\end{array}$ & * & $\begin{array}{l}\text { Malaysia's growing public (and private) debt markets will } \\
\text { provide plenty of opportunity for banks to collude in bidding. }\end{array}$ \\
\hline $\begin{array}{l}\text { Tying loan insurance } \\
\text { to loans }\end{array}$ & $\stackrel{*}{-}$ & $\begin{array}{l}\text { Certain tying arrangements in Malaysia possible (like anywhere). } \\
\text { Yet, tying may actually help create markets in the short-term in } \\
\text { Malaysia's lesser developed markets. }\end{array}$ \\
\hline $\begin{array}{l}\text { Colluding on IPO } \\
\text { fees and other } \\
\text { investment advisory }\end{array}$ & $\stackrel{*}{*}$ & $\begin{array}{l}\text { Collusion in fees for underwriting and advisory activities is } \\
\text { relatively harder to detect in Malaysia, given fewer players in the } \\
\text { market and limited publicly available information. }\end{array}$ \\
\hline
\end{tabular}

\footnotetext{
${ }^{11}$ Lynch in particular provides an overview of the types of recent anti-trust scandals affecting banks and speculates on the compliance cost of these investigations. See Niall Lynch, Antitrust agencies up scrutiny of banking industry, LATHAM \& WATKINS BRIEF, 2011, available online.

${ }^{12}$ We do not address antitrust issues in potential mergers and acquisitions, as these receive special due diligence by both participants in the merger and regulators. The Malaysian Competition Act makes no provision for merger control - making any discussion of such merger control irrelevant for our purposes.

${ }^{13}$ See OECD, COMPetition AND Regulation In RETAil BANKING, 2006, available online.
} 


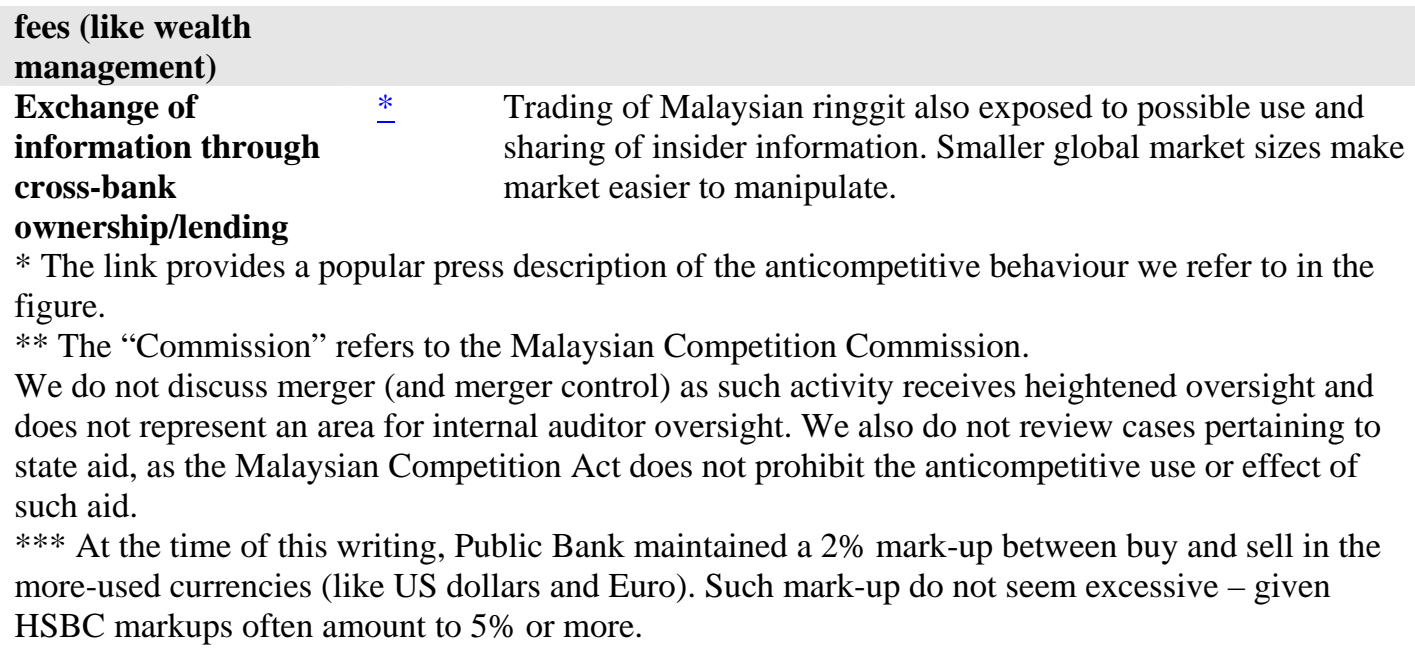

* The link provides a popular press description of the anticompetitive behaviour we refer to in the figure.

** The “Commission” refers to the Malaysian Competition Commission.

We do not discuss merger (and merger control) as such activity receives heightened oversight and does not represent an area for internal auditor oversight. We also do not review cases pertaining to state aid, as the Malaysian Competition Act does not prohibit the anticompetitive use or effect of such aid.

*** At the time of this writing, Public Bank maintained a 2\% mark-up between buy and sell in the more-used currencies (like US dollars and Euro). Such mark-up do not seem excessive - given HSBC markups often amount to $5 \%$ or more.

If the Competition Commission's caseload looks anything like the EU's, price fixing investigations may represent the majority of these cases. Figure 3 shows the types of cases dealt with by the EU's Directorate General for Competition since roughly $2000 .{ }^{14}$ Most of these cases involve price fixing (of interest rates and exchange rates). In terms of the financial services sub-sector, DG-Competition dealt with securities cases more often than other types of cases. The number of cases over the period does not exceed 30 - showing that financial services either have remained competitive or antitrust agencies have not placed monitoring and/or investigations in the sector as a high priority. ${ }^{15}$

When the Commission decided to take up antitrust issues in financial services, such a focus usually corresponded with strong political incentives to take action. Figure 4 shows the change in media mentions of competition-related stories about financial services in the global media. At times when anticompetitive behaviour in the Union's (former the European Communities') financial services sector became a significant concern, the Commission appears to have responded. Credit markets have continued to attract the greatest interest in the media.Unsurprisingly, the Commission’s lackadaisical investigations into collusion by portfolio managers has mirrored the public's scant interest in this issue.

\footnotetext{
${ }^{14}$ We show only cases dealt with by DG-Competition and not the Member States' competition authorities themselves. Such data are probably the most relevant for Malaysia - as the Malaysian Competition Commission will want to deal with high-value cases of a "Union” nature (affecting all off Malaysia rather than one state). See DG-Competition, Antitrust Cases: Financial and Insurance Activities, 2014, available online.

${ }^{15}$ The EU pursued most of these cases as the result of political pressure - with euro exchange rate collusion cases coming when the EU had the development of the euro as a key priority and expressed interest in collusion among financial institutions during and after the global financial crisis. For more on the political inspiration behind the EU's antitrust work in financial services, seeBecket McGrath, Banking in the Antitrust Crosshairs - the EU Situation, Edwards Angell Palmer \& Dodge Client Advisory, 2010, available online. For a more political spin, see Joaquin Almunia, Opening a Path for Recovery: Competition in Financial Markets, SPEECH/14/108, 2014, available online.
} 


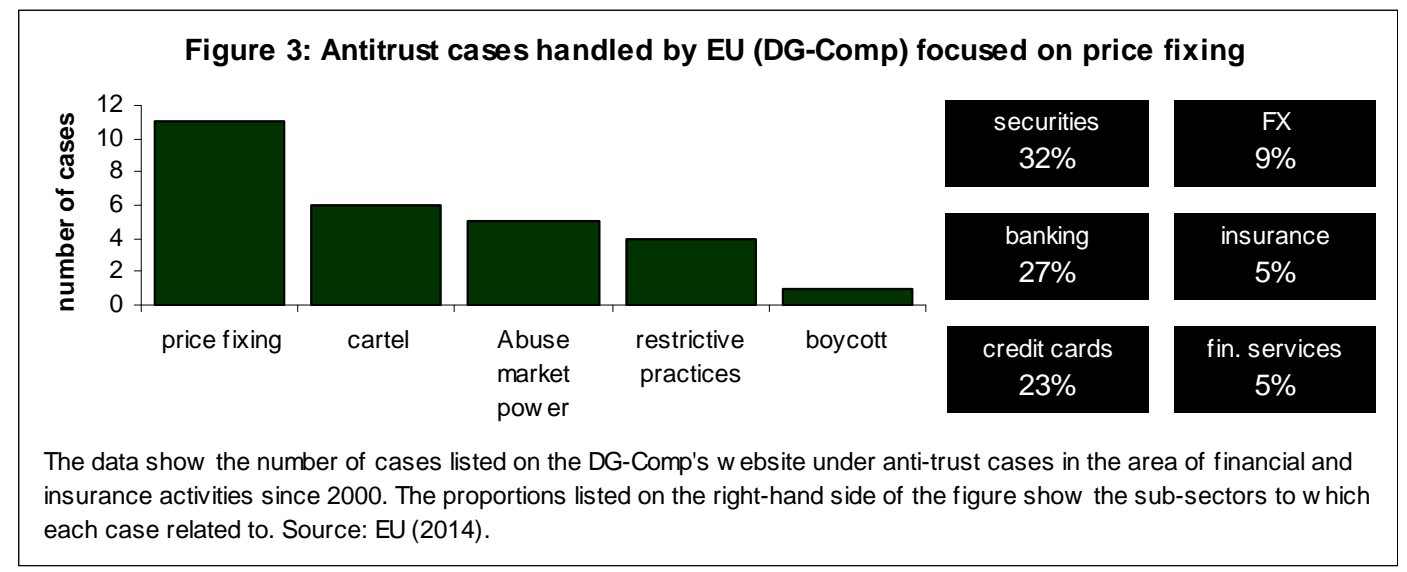

\section{Figure 4: Financial Sector Antitrust Enforcement Depends on External Political Incentives?}
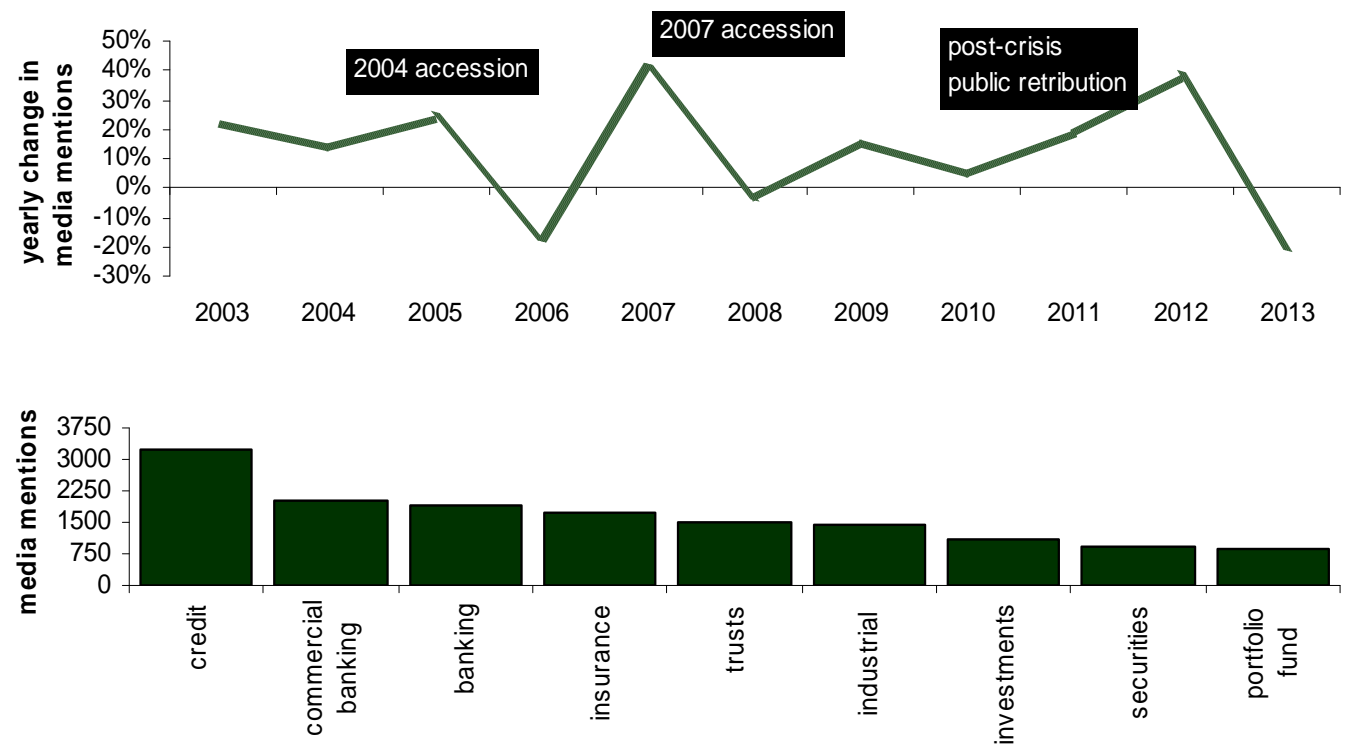

The figure shows the amount of popular interest in competition issues, as recorded by media citations of "competition", "financial services" and "EU."

Source: Factiva (2014).

If foreign experience serves as a guide, the Malaysian Competition Commission will not be able to enforce antitrust law in the same way as in other domestic industries for several reasons. First, financial service firms (like banks) must comply with far more intrusive regulation than in many other industries. ${ }^{16}$ Many of these regulations emanate from banking or securities regulators which might impose their own rules that can impact on competition in the financial services markets. ${ }^{17}$ Second, banking regulation may purposely seek to restrict competition

\footnotetext{
${ }^{16}$ Naturally, Malaysia has other regulated sectors as well. However, following the international trend, financial services remain relatively highly regulated.

${ }^{17}$ In the past, many central banks and banking regulators imposed ex ante rules preventing anticompetitive behaviour by banks. Such rules reduced the need for ex post checks by a competition
} 
(by restricting prices, quantities and competition) in order to promote banking stability. ${ }^{18}$ In such a situation, the Competition Commission must focus its work on the regulations themselves - rather than the conduct such regulation engenders. Third, banking and securities markets represent particularly international forms of market activity. Foreign banks hold over $50 \%$ of deposits in the Malaysian banking sector. ${ }^{19}$ If foreign banks hold Malaysian assets (and liabilities), Malaysian banks also hold such assets and liabilities abroad. In these cases, the Malaysian Competition Commission may need to look at Malaysian financial services companies' operation outside of Malaysia (though of course domestic-only cases will still represent the majority of investigations). The cross border nature of banking makes Malaysian banks open to the extra-territorial application of the Malaysian Competition Act as well as the activity of foreign competition authorities in whose jurisdictions Malaysian banks either operate or may affect. ${ }^{20}$

If the EU past experience foreshadows Malaysia's, Malaysian banks can expect four trends which will affect these banks' antitrust compliance costs and benefits. ${ }^{21}$ First, the difficulty involved in spotting anticompetitive behaviour combined with market-specific factors that tend to reduce competition in banking will mean few banking cases are likely to be brought under the Malaysian

agency. The creation of financial conduct authorities (which hold responsibility of overseeing all possible misconduct by financial institutions) has removed some of the jurisdictional boundaries between banking regulators and competition authorities. For more on the way a consolidated financial conduct authority can remove the competition policy enforcement divide between the banking regulator and the competition authority in the UK context, see Richard Eccles, Martin Sandler, Michael Brown, UK: Competition Law powers of the Financial Conduct Authority, BIRD \& BIRD CLIENT ADVISORY, 2013, available online. For a more general discussion, see James Wilcox, The Increasing Integration and Competition of Financial Institutions and of Financial Regulation, 22 RESEARCH IN FINANCE, 2005, available online.

${ }^{18}$ Numerous scholars write about the trade-off between the gains from a highly competitive banking system and the potential risks to banking stability that thin profit margins and excess risk-taking may pose. See Todd Fishman, Olivier Freget, and David Gabathuler, U.S. And EU Antitrust Enforcement: What Role in a More Heavily Regulated Financial Sector? 7 COMPETITION POLICY INTERNATIONAL 2, Fall 2011. For empirical support, see Luigi Guiso, Paola Sapienza and Luigi Zingales, The Cost of Banking Regulation, EUI Working Papers ECO 2007/43, available online.

${ }^{19}$ IMF, Malaysia: Financial Sector Stability Assessment, COUNTRY REPORT 13/52, at Figure 5, available online.

${ }^{20}$ See Competition Act, 2010, at s.3(1). Any discussion of the cross-border enforcement of banking sector antitrust rules clearly requires a separate paper (or book!) in its own right. For an overview of the issues, see Salil Mehra, Extraterritorial Antitrust Enforcement and the Myth of International Consensus, 10 DuKE J. COMP. \& INT'L. L. 191, 2000, available online. See also Brendan Sweeney, Combating Foreign Anti-Competitive Conduct: What Role ForExtraterritorialism?8 MEL. J. OF INT'L L., 2007, available online.

${ }^{21}$ We focus on the EU experience as the EU's antitrust enforcement is far more transparent than the US's. While the US Department of Justice provides cases online and the major US law firms offer briefings on the subject, the US market for antitrust information hides behind paid infomediaries. Even the most cursory comparison of the US Federal Trade Commission and DG-Competition's websites will show the remarkable difference in accessibility of the two Union/Federal bodies. For an obvious example of the FTC's impenetrability, see Jon Leibowitz, The Role of the Federal Trade Commission in Protecting Consumers, Prepared Statement Before the Committee On Commerce, Science, and Transportation of the United States Senate, 2010, available online. 
Competition Act. ${ }^{22}$ Second, international experience suggests that the Malaysian Competition Commission will probably focus on anticompetitive price fixing rather than quantity/quality restrictions. Both the EU (DG-Competition) and Member States have seemed to focus on price rather than quantity restrictions in the past 10 15 years. Third, Malaysia's financial service firms will need to spend more time comprehending financial sector specific antitrust regulations (and who makes them - the banking and financial services regulators) rather than focus on the actual conduct. The EU experience exemplifies the problem with multiple regulators and the lack of cases, as the EU's Directorate General for Competition tackled anticompetitive behaviour in banking hesitantly and seemingly only in response to political pressure). Indeed, international experience shows that Malaysian financial institutions are probably safe from the Malaysian Competition Commission until the next banking/financial crisis as a result of the Commission's current oversight. ${ }^{23}$ Fourth, coordination between domestic regulators (Bank Negara and Competition Commission) and foreign regulators (particularly the Singaporean Competition Commission and EU Member States' authorities) will pose difficulties for the foreseeable future - for all kinds of cases (domestic and international).

\section{Anti-Competitive Behaviour is Probably Higher than in Many Other Countries}

Banks in Malaysia appear to enjoy the levels of market power not seen in other jurisdictions. Figure 5 provides estimates of market power in various banking sectors in a range of countries. ${ }^{24}$ Market power, in this instance, refers to the extent to which banks mark-up rates and fees above the marginal cost of providing those services. ${ }^{25}$ Malaysia ranks as the $40^{\text {th }}$ "worst" country --with an adjusted Lerner score of 0.26 . Such a rank means that 39 countries have higher levels of banking sector market power and that prices in the Malaysian banking sector exceed their marginal cost (or the best possible price) by $26 \% .{ }^{26}$ Such mark-ups pose three

\footnotetext{
${ }^{22}$ Banking (particularly retail banking) has features which may make "natural” high concentration, low levels of switching, a lack of pricing transparency and large entry barriers normal. For a discussion in the UK context, see Cosmo Graham, Competition Law and UK Retail Banking, 2013, available online. As early as the 1980s, scholars argued that such natural barriers to competition meant that the banking sector should be subjected to more control from competition authorities. See Joseph Bauer, Competition at the Teller's Window? Altered Antitrust Standards for Banks and Other Financial Institutions, 35 U. OF KAN. L. REV, 1987.

${ }^{23}$ Such a reaction may represent competition authorities' rational decisions rather than a lily-livered reaction to politics. Banks may engage in anticompetitive behaviour in order to boost risk-adjusted yields exactly at times when financial markets are most susceptible to crises. See John Boyd and Gianni De Nicolo, The Theory of Bank Risk-Taking and Competition Revisited, 60 J. OF Fin. 3, 2005, available online.

${ }^{24}$ See Sofronis Clerides, Manthos Delis and Sotirios Kokas, A New Data Set on Competition in National Banking Markets, UNI. OF CYPRUS WP 08-2013, 2013, available online.

${ }^{25}$ The authors specifically refer to the Lerner Index. The Lerner Index measures the difference between prices and marginal costs, expressed as a proportion of prices. Economists will recognise that this relationship also represents a function of the bank's price elasticity of demand. We refer to other measures of market power in this paper.

${ }^{26}$ The authors use bank income as a proxy for the price of banking services and use the price of labour, capital and other banks' inputs in determining marginal costs. See Id at Table 3.
} 
threats for Malaysian banks (and financial services institutions more generally). First, whether justified or not, customers may complain that Malaysian banks engage in horizontal or vertical agreements which bestow such market power. ${ }^{27}$ Second, customers may complain that banks "abuse" such market power to charge higher prices, restrict banking services, and so forth. ${ }^{28}$ Third, such market power has international effects, which prevents foreign competitors entering or contesting the market, thereby affecting actual and/or potential customers abroad. ${ }^{29}$

\section{Figure 5: Malaysia Ranks Relatively Badly for Banking Sector Market Power}

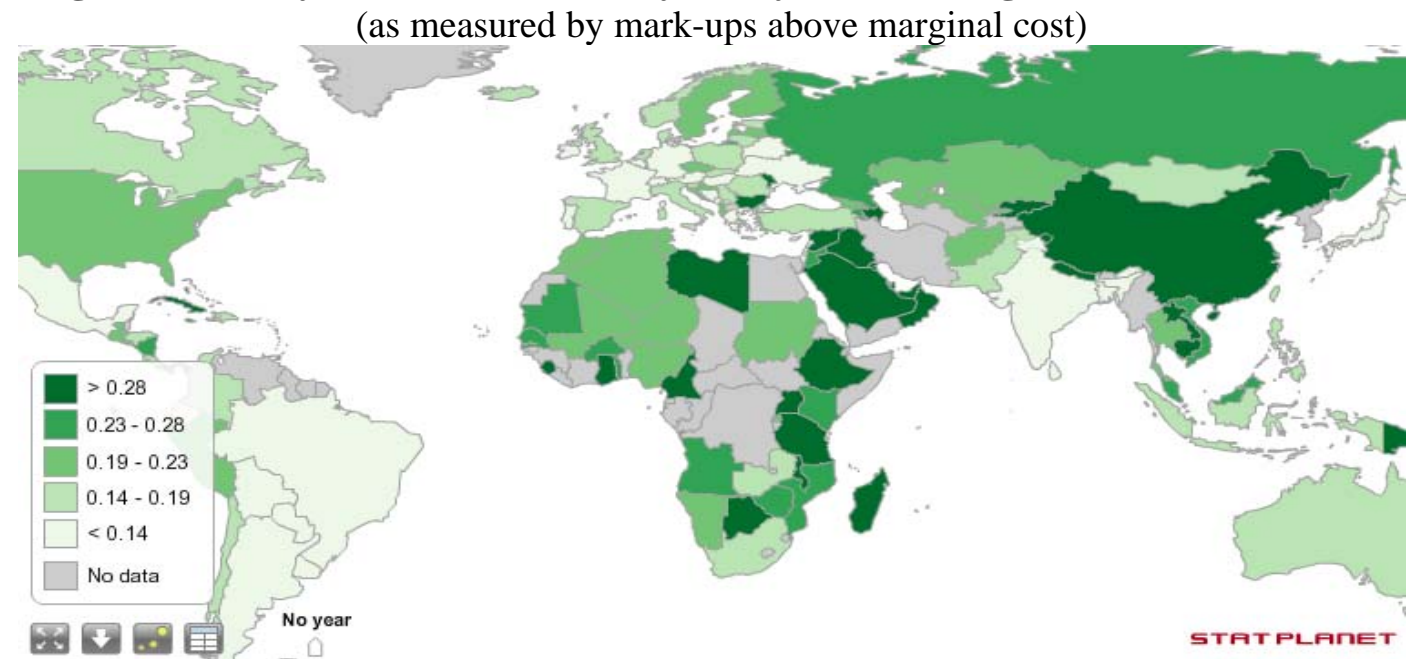

The data in the figure show adjusted Lerner Index values for each of the countries shown in the figure.

Source: Clerides and co-authors (2013).

Banking sector concentration in Malaysia both causes and results from such market power. Figure 6 shows the extent to which a small group of banks (namely three) represent asset ownership, loan writing, and deposit-taking in the Malaysian banking sector as a whole. ${ }^{30}$ The largest 3 banks held slightly less than half of all loans, assets and deposits until about 2006. Concentration increased slightly before the global financial crisis. Many competition authorities and/or financial regulators use concentration ratios of about $40 \%-50 \%$ as a threshold in deciding whether banks have and/or are able to exploit their dominant positions. By this criterion,

\footnotetext{
${ }^{27}$ The Competition Act criminalises such agreements in Chapter 1. Customers may complain to the Malaysian Competition Commission or to the courts under a private right of act (meaning they can sue by themselves in court).

${ }^{28}$ Chapter 2 of the Competition Act criminalises such abuse. Because market power exists, customers will find it easier to complain about anything that makes their banking experience less pleasant as a restraint on quantity/quality of service and/or an increase in actual price (including things like queuing times and so forth). For reports about such complaints (and the risks they pose), seeDaljitDhesi, Malaysian banks take heed of complaints, making huge investments to improve services, STAR, 25 Mar., 2013, available online.

${ }^{29}$ In other words, Malaysian banks become exposed to foreign competition laws to the extent foreign complainants and/or litigants can prove such market power affects them outside of Malaysia.

${ }^{30}$ SeeFadzlanSufian, Muzafar Shah Habibullah, Financial sector consolidation and competition in Malaysia: An application of the Panzar-Rosse method, 40 J. OF ECON. STUD. 3, 2013.
} 
Malaysian banks clearly have concentration ratios which would normally raise the suspicions of competition authorities' that such banks have the ability to abuse that market power.

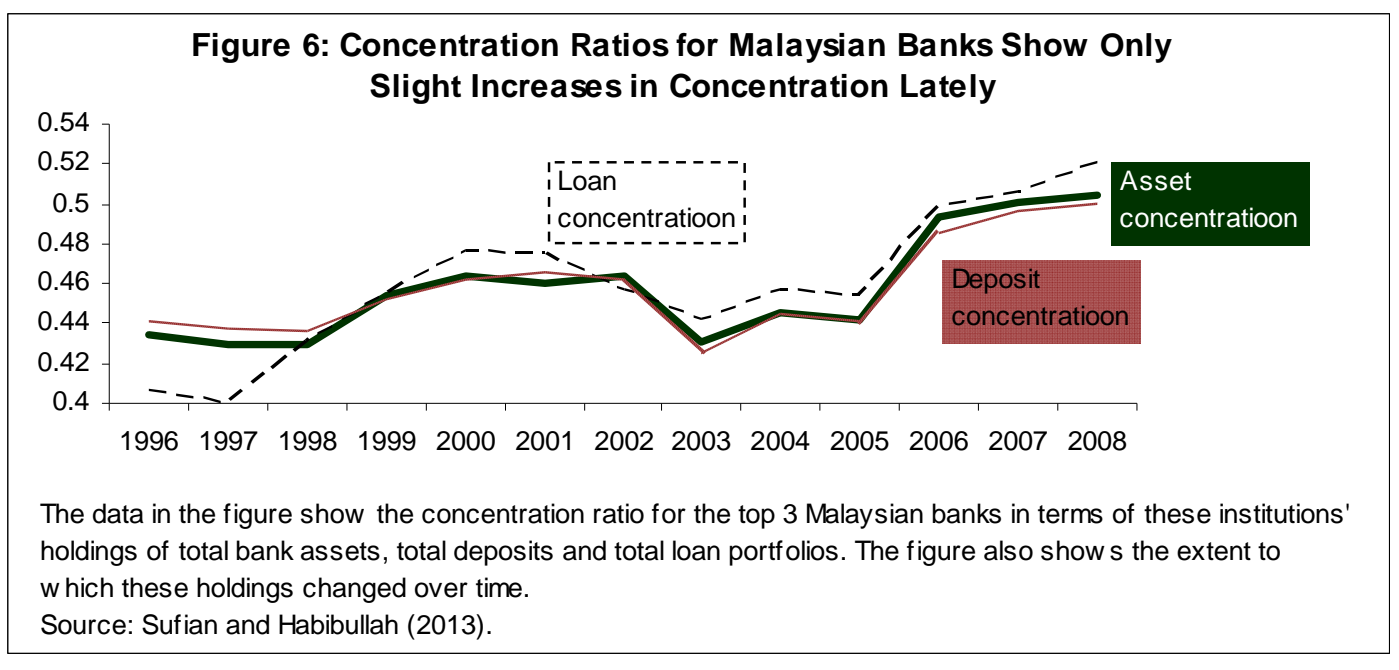

Yet, concentration, higher prices and lower quantity/quality of lending probably reflect inefficiency rather than more sinister anticompetitive motives. Malaysia's inefficient banks cannot provide all the services demanded by customers (at the price they want). They lack resources needed to compete in new markets. ${ }^{31}$ Regulation - or lack thereof - also clearly has a role to play in determining competitive pressures in Malaysia's banking and financial services sectors. ${ }^{32}$ Figure 7 shows the extent of competition in Malaysian banking from roughly 1998 to 2005. The measure of competition focuses on the extent to which banks can pass onto their customers increases in input prices (like the cost of tellers, the bank's rental payments and so forth). In a perfectly competitive market, banks would have no significant mark-ups - meaning they must fully pass-on costs to their customers. The Malaysian banking sector exhibits monopolistic competition - with about $70 \%$ of costs passing on to customers around 2005. After the regulatory changes adopted around 2002, competitive forces in Malaysia’s banking sector increased

\footnotetext{
${ }^{31}$ A number of studies show a purported link between the generalised lack of competition and inefficiency in Malaysia's banking sector. See Rossazana Ab-Rahim, Nor-Ghani Md-Nor and Mohamad Jais, Concentration, Competition and Efficiency in Malaysian Banking Industry, FEB WP 1112, 2011, available online. Interestingly, Malaysia represents one of the countries with the most number of studies publicly available about the efficiency of its banks. As with most questions in economics, economists studying Malaysia's banks do not agree on the extent to which lack of competition stems from inefficiency (or even if such inefficiency exists!). For some of the recent studies, seeIzah Tahir, Nor Bakar and SudinHaron, Evaluating Efficiency of Malaysian Banks Using Data Envelopment Analysis, 4 INT’L J. OF Bus. \& MAN. 8, 2009, available online. See also Farhana Ismail, Rossazana Rahim, and Shabri Majid, Determinant of Efficiency in Malaysian Banking Sector, 43 InT’L PRO. OF ECON. DEV. \& RES., 2012, available online.

${ }^{32}$ For a discussion, see Muhamed Majid and Fadzlan Sufian, Consolidation and Competition in Emerging Market: An Empirical Test for Malaysian Banking Industry, 39 ECON. CHANGE \& RESTRUCT. 1, 2007
} 
significantly. Competition law did not increase competition in Malaysia’s banking system; deregulation did.

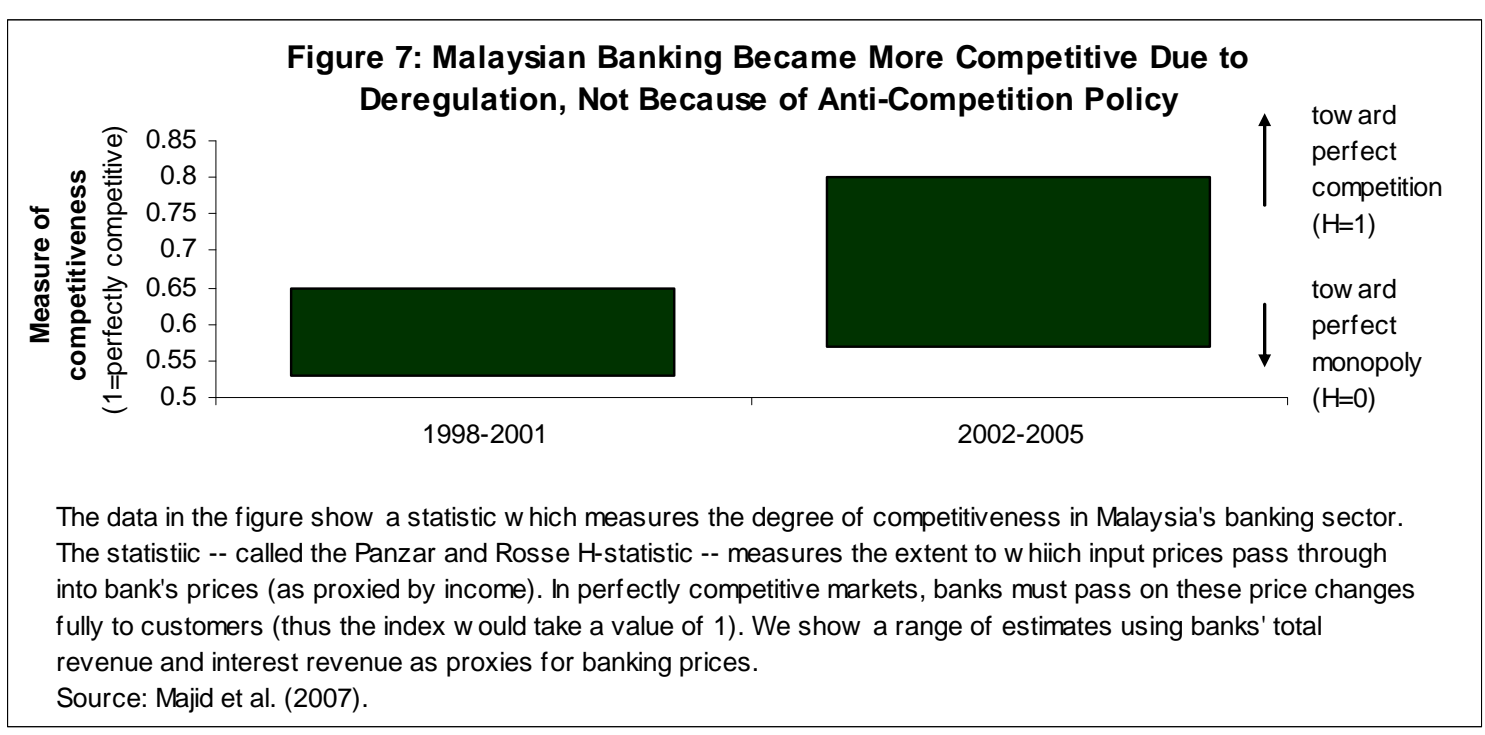

Low net interest margins suggest that Malaysian banks cannot take advantage of their market power (probably for regulatory reasons). Figure 8 shows bank profitability (as measured by net interest margins) for Malaysian banks since 2005. Malaysian banks have consistently earned significantly lower margins than their peers in other jurisdictions like Hong Kong and Singapore. Lending and deposit rates have remained consistently higher than other countries - suggesting that government policy has created a situation in which Malaysian banks cannot compete on price as they would like. ${ }^{33}$ Lending rates in Malaysia, Hong Kong and Singapore have hovered around 5.5\%. Yet, deposit rates in Malaysia have been 2\% higher. Either deposit rates (basically set by Malaysia's central bank) are too high, or lending rates are too low. ${ }^{34}$ Such data strongly suggests that regulatory distortions have negatively affected banking competition in Malaysia.

\footnotetext{
${ }^{33}$ An extremely competitive banking environment may also explain these data. However, we have difficulty believing that competition in the Malaysian banking sector forces interest rates and profit margins to diverge from trends in two very competitive markets (Hong Kong and Singapore). As such, we assume (rightly or wrongly) that regulatory distortions must be at play.

${ }^{34}$ Higher central bank rates reflect normal monetary (and exchange rate) policy. Nevertheless, the higher cost of capital still appears to drag down bank profits - leading to our observation about regulatory distortions. We do not claim these distortions are illegitimate or unfair - simply that they exist.
} 


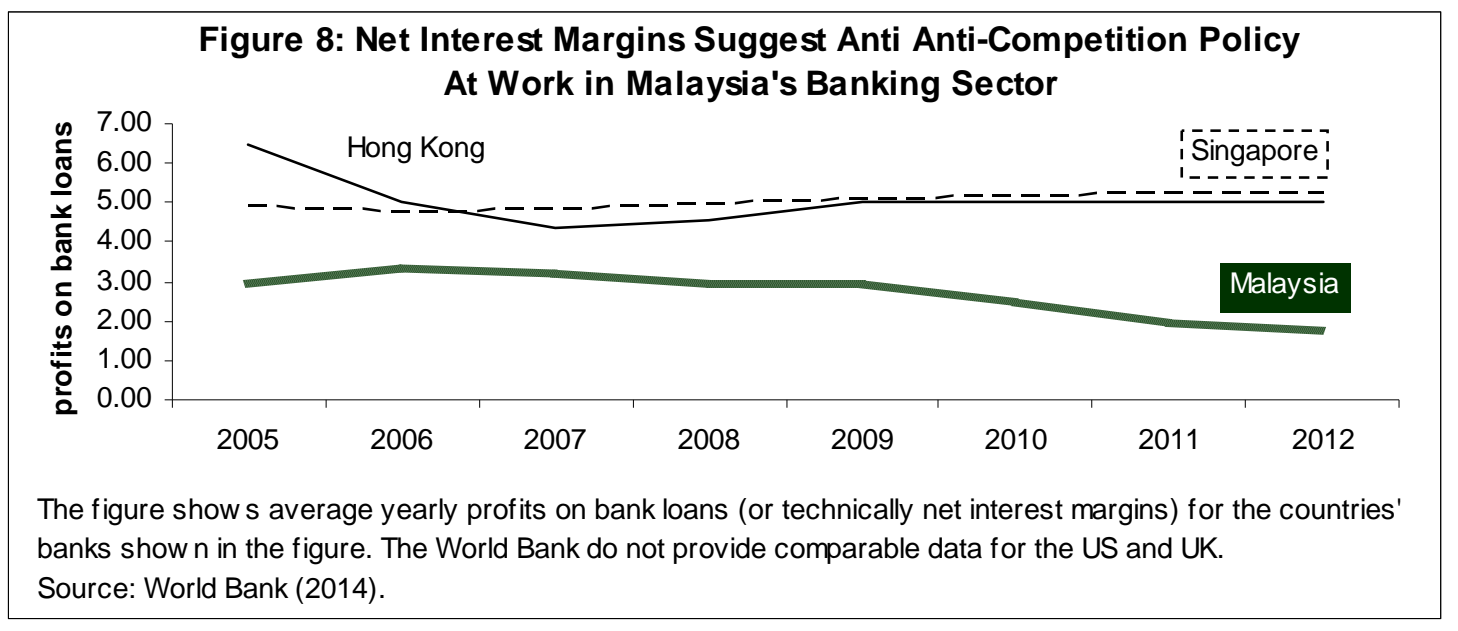

Fortunately, cursory examination of the evidence suggests no obvious collusion or abuse of market power in Malaysian banking. Figure 9 shows lending volumes for several of Malaysia's largest banks (to take a representative sample of these banks). As shown in the figure, lending by one bank does not seem to "rely" on lending by another bank. Attempts to create market power or horizontal agreements for later abuse often show up in data as contemporaneous or cross-time correlation. However - and particularly after the financial crisis - lending by Malaysia's banks seems completely unrelated to lending by other banks. Simple correlation coefficients (shown below the figure) indicate that lending by banks seems either statistically positively or negatively correlated. However, no systematic trends appear in these data to suggest collusion between banks.

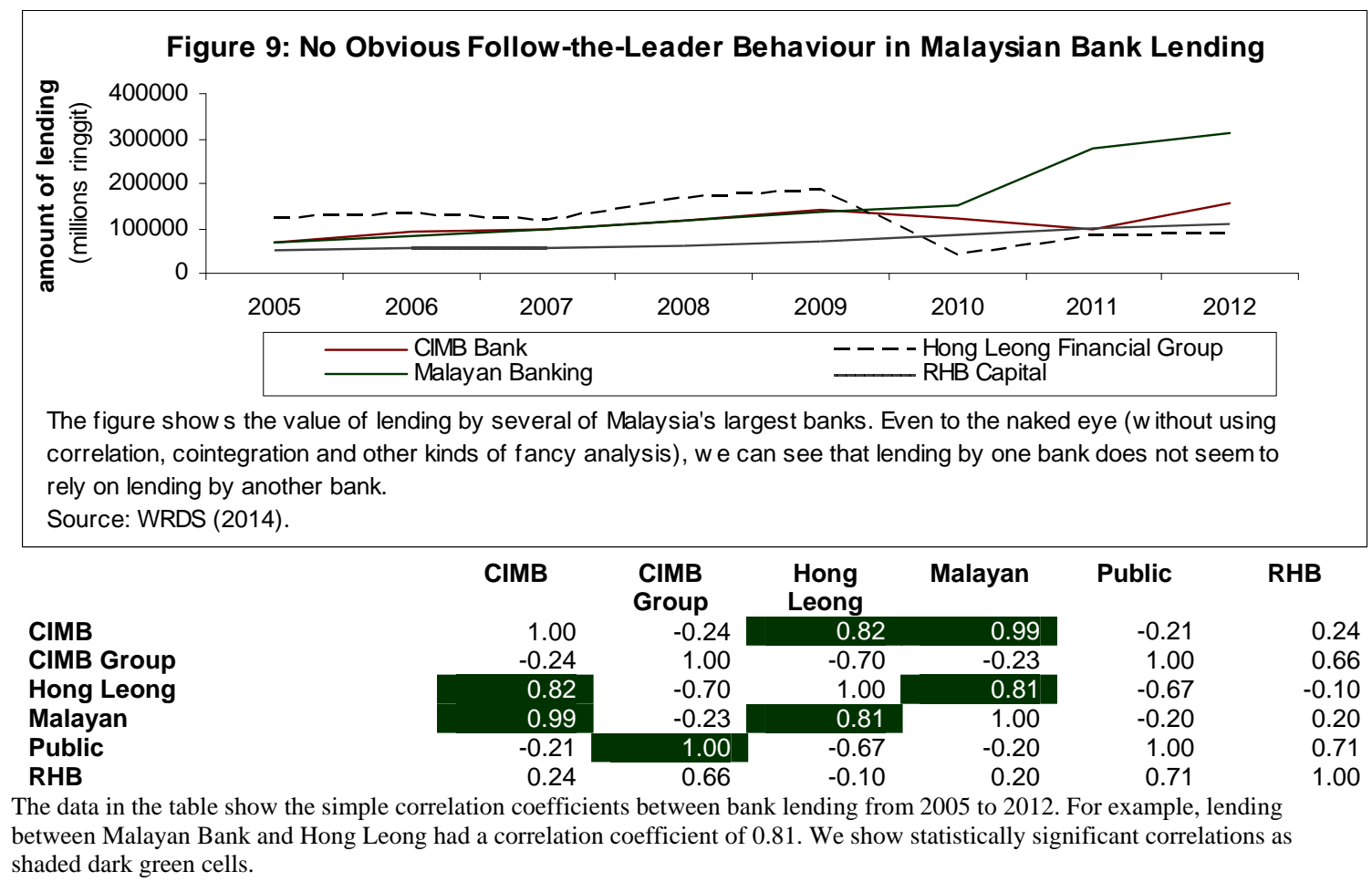


More advanced analysis also fails to find evidence of any obvious anticompetitive behaviour among Malaysia's banks. Figure 10 shows an example of several clustering analyses we conducted on Malaysian bank balance sheets. To describe a complex procedure simply, we asked our statistical software to look at a host of balance sheet variables (like loans, profits, and so forth) and detect a pattern across banks. If groups of variables (like expenses, fee income or other variables) statistically significantly correlated among any group (or subgroup) of banks, the software would put these banks into separate groups. ${ }^{35}$ Without going into unnecessary detail, if banks formed groups which colluded with each other in order to compete with other bank groups, we might find similar variance in lending, profitability or other variables. We did not find any such results. Our analysis could only find one group - suggesting either no collusion or complete collusion. Given other data we have presented previously, regulation and other factors probably explain such a grouping better than any sinister, system-wide banking cartel.

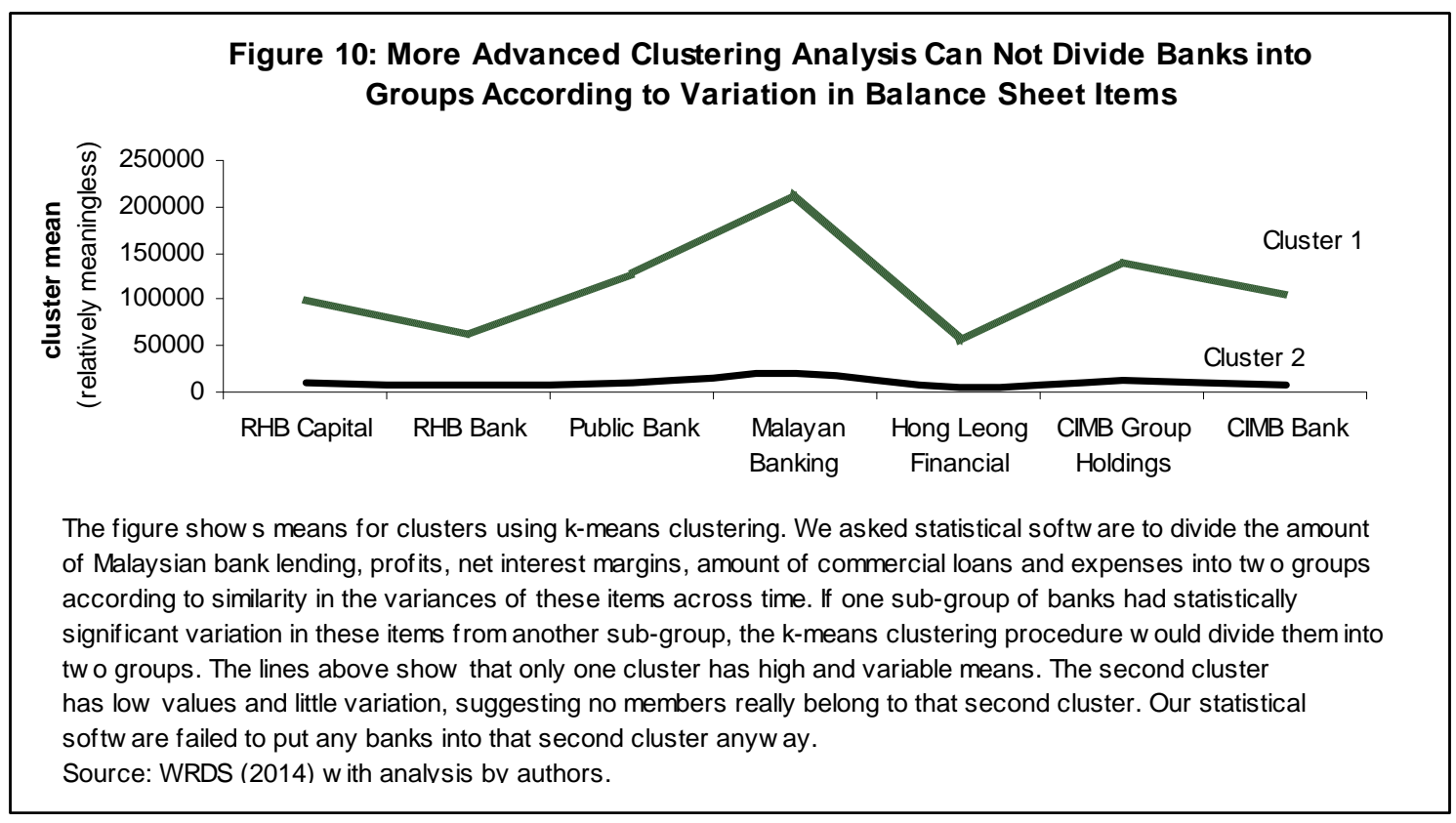

\section{Anti-Competitive Behaviour Probably Stems from Collusion within Government and/or Family Social Networks}

For all these seemingly positive results, the ownership and control structure of Malaysia's banks very likely leads to anti-competitive behaviour. The structure of the financial sector is the cause of anticompetitive behaviour - promoting certain types of potential anti-competitive conduct. Financial conglomeration and the crossinstitutional control of Malaysia's financial institutions by the government and

${ }^{35}$ We could not hope to review the literature or studies which use econometric tools to detect collusion or other anticompetitive practices in the banking sector. For a recent example, see Rosa Abrantes-Metz, Michael Kraten, Albert Metz and Gim Seow,Libor manipulation?, 36 J. OF BANK. \& FIN., 2012. 
families likely reduces actual competition in Malaysia's financial service markets. Financial conglomerates (particularly those with a financial institution at their centre) have strong incentives to distort the allocation of capital. The IMF has pointed to CIMBGroup, RHB Group, Affin Group, Alliance Group, Hong Leong Group and AmBank Group, as financial conglomerates headed by a financial holding company. ${ }^{36}$ The IMF also mentioned Maybank Group and Public Bank Group, which represent financial conglomerates headed by a banking institution. Financial groups will always balance finance promotion with financial diversion. ${ }^{37}$

The data strongly suggests that government and family "insider" ownership and control provide strong incentives for banks to engage in anti-competitive capital allocation (and/or favourable pricing behaviour). Figure 11 shows the share of government ownership and family share of such ownership of Malaysian banks in 2003. While the figure uses very old data, the conclusion still remains correct. Extensive government (and family) control of Malaysian banks provides strong incentives for such banks to act anti-competitively. ${ }^{38}$ Figure 12 shows the historical proportions of government ownership in Malaysia's largest companies (as judged by market capitalisation). ${ }^{39}$ In many of these cases, government held a $50 \%$ or greater share. When the same entity controls both the borrower (or several borrowers) and lender (or several lenders), strong incentives appear to provide anticompetitive advantages. ${ }^{40}$ Yet, how do we know that such government and family control actually causes anticompetitive behaviour?

\footnotetext{
${ }^{36}$ See IMF, Malaysia: Financial Sector Stability Assessment, IMF COUNTRY REPORT 13/52, 2013, available online, at footnote 8 .

${ }^{37}$ Financial conglomerates, especially those with close linkages to industrial firms, tend to both promote and divert finance to allied firms. From an antitrust perspective, such diversion may both break the law as well as achieve sub-optimal economic outcomes. More worryingly, such conglomerates may have bargaining power vis-à-vis regulators which make the enforcement of antitrust or macro-prudential policies less likely. For a rather dated (but still relevant) discussion involving Malaysia, see Paola Bongini, Stijn Claessens, and Giovanni Ferri, The Political Economy of Distress in East Asian Financial Institutions, 19 J. OF FIN. SERV. RES. 1, 2001.

${ }^{38}$ We do not have space to review decades of literature showing how state ownership and/or control often leads to the anti-competitive allocation of capital. See David Sappington and Gregory Sidak, Anticompetitive Behavior by State-Owned Enterprises: Incentives and Capabilities, In Rick Geddes, COMPETING WITH THE GOVERNMENT: ANTICOMPETITIVE BEHAVIOR AND PUBLIC ENTERPRISES, Hoover, available online.

${ }^{39}$ See Razak, Nazrul, Rubi Ahmad, and Huson Aliahmed, Government Ownership And Performance: An Analysis Of Listed Companies In Malaysia, 6 CORP. OwN. \& CONTROL 2, 2008, available online. ${ }^{40}$ Most of the studies we cite find that Malaysian government ownership of a financial organisation correlates with statistically significantly positive earnings and/or return on equity. Either we must believe that government has superior managers or that its banking managers engage in anticompetitive behaviour which leads to higher returns. For an example of a study finding higher return on equity in the Malaysian Islamic banking context, see Shamsuwatd Abbas, Rashidah Rahman and Sakthi Mahenthrian, Ultimate Ownership and Performance of Islamic Financial Institutions in Malaysia, Paper Prepared for the Asian Finance Association Conference, 2009, available online.
} 


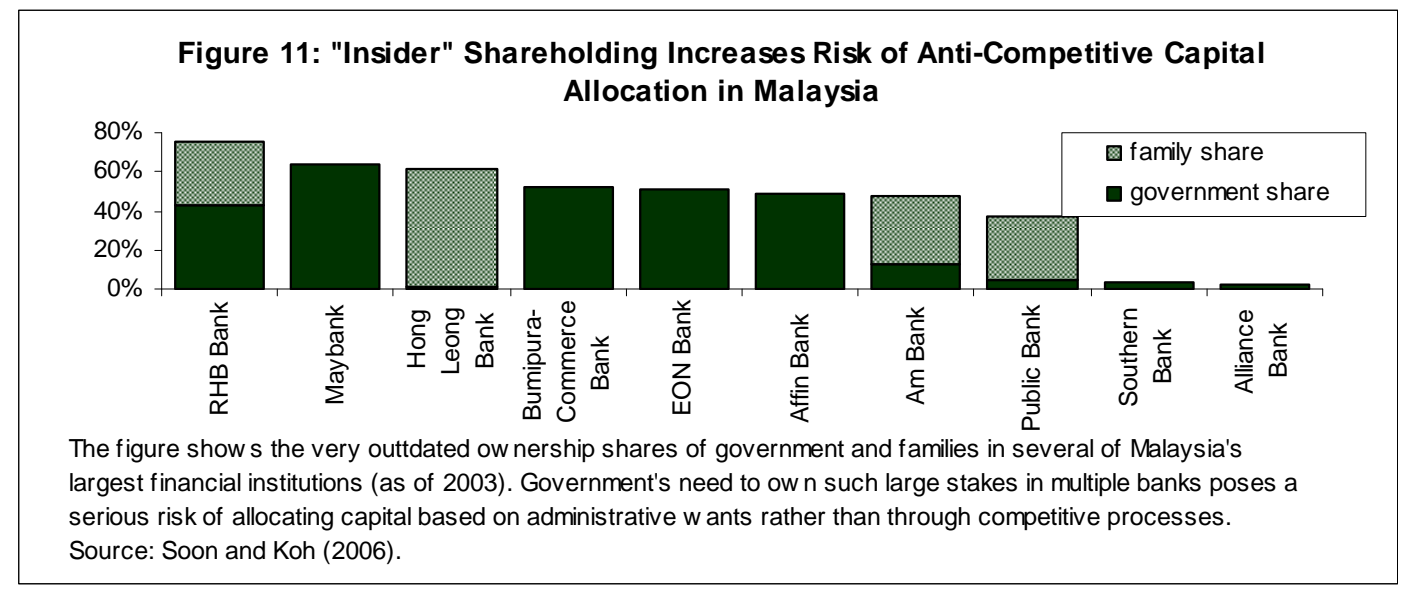

Figure 12: When Government Owns a Large Stake in Bank and Company, the Likelihood of Anti-Competitive Capital Allocation Increases

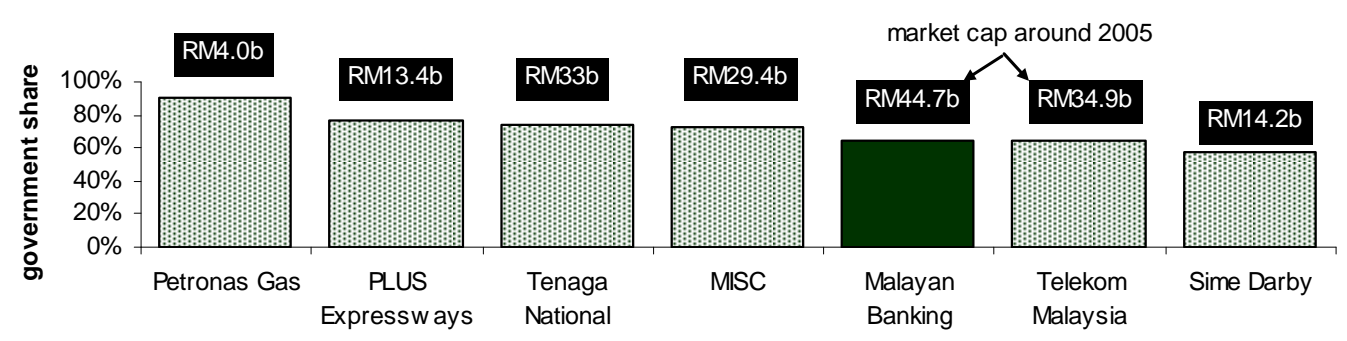

The data in the figure show the share of government ow nership in various large Malaysian companies. We show the market capitalisation at the time Razak and co-authors came out $w$ ith their study.

Source: Razak et al. (2008).

We cannot know for certain that government ties between banks and companies (and between companies themselves) leads to anticompetitive behaviour. ${ }^{41}$ Yet, we do know that extensive government (and other group) holdings in financial, as well as non-financial companies (particularly clients), creates strong incentives to abuse market power. Numerous authors, both generally and in the Malaysian context, have written about the way cross-holding affects incentives. Claessens et al. have noted that group affiliation (basically belonging to a group by ownership and/or control) in Asia leads to higher firm value, except for younger and more dynamic companies. ${ }^{42}$ Such groups clearly use "mechanisms" (of which some can be anticompetitive) to benefit their members. In all cases, common ownership/control dulls the learning and efficiencies that come about as a result of competition. For older firms, such dulling provides benefits (in the form of rents). For younger firms,

\footnotetext{
${ }^{41}$ A rigorous study would correlate anticompetitive behaviour (probably as discovered through Competition Commission cases) with ownership and control data. As the Malaysian Competition Commission has just started working (in 2010), we have quite a long time to wait before scholars can write such studies.

${ }^{42}$ See Stijn Claessens, Joseph Fan, and Larry Lang, The benefits and costs of group affiliation: Evidence from East Asia, 7 EMERGING MARKETS Rev. 1, 2006.
} 
such a dulling of competitive pressure deters innovation and encourages the funding of projects that may not have the highest market value. ${ }^{43}$

Indeed, related party transactions affect some sectors more than others - and state ownership seems to appear in most of these related party transactions. Figure 13 shows the value and number of related party transactions among Malaysian companies in recent years. ${ }^{44}$ Manufacturing, consumer goods and mining companies had the highest value of related party transactions. Companies with extensive government ownership/control have higher proportions of related party transactions. Figure 14 shows correlations between various aspects of company structure and ownership. Government owned companies had statistically significantly higher levels of related party transactions. They also had higher levels of debt - raising concerns about the anti-competitive grant of debt that may be given (and forgiven) more easily to government than non-government companies.

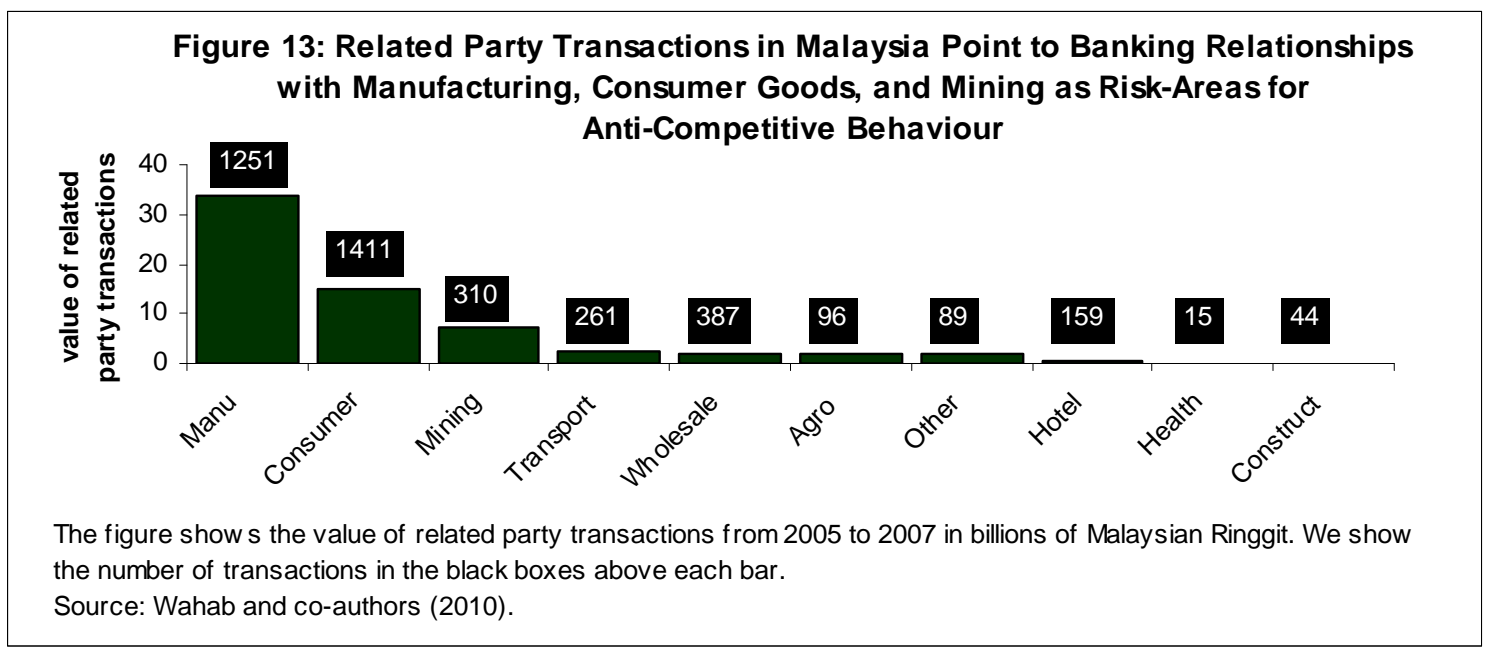

\footnotetext{
${ }^{43}$ Soon and Koh provide an older study, also showing extensive government and family ownership ties. Yet, their data fail to show a relationship between government bank ownership and harm (like decreased returns on assets). Se eLum Soon and Philip Koh, Corporate governance of banks in Malaysia, In Sang-Woo Nam and Chee Soon Lum, Corporate GovernanCE OF BANKS IN Asia, 2006, available online.

${ }^{44}$ See Effiezal Wahab, Hasnah Haron, Char Lee Lok, and Sofri Yahya, Does Corporate Governance Matter? Evidence from Related Party Transactions in Malaysia,14 ADVANCES IN FIN. ECON. 1, 2011, available online.
} 


\section{Figure 14: Government Involvement in Malaysian Companies Clearly Has an Effect on Related Party Transactions and Other Company Factors}

\begin{tabular}{|l|l|l|}
\hline Factor & Family & Government \\
\hline Number of related party transactions & $*$ & positive \\
\hline Assets in related party transactions & negative & $*$ \\
\hline Proportion of independent board directors & $*$ & $*$ \\
\hline Number of directors on Board & positive & $*$ \\
\hline Audited by Big 4 & $*$ & $*$ \\
\hline Assets & negative & $*$ \\
\hline Debt & negative & positive \\
\hline Number of interlocking directors & positive & $*$ \\
\hline
\end{tabular}

The figure shows the extent to which family and government ownership correlates with the factors shown in regression analysis. "Positive” indicates a positive correlation and "negative" indicates a negative one.

Source: Wahab et al. (2010).

We know that government ownership - and the related party transactions such ownership and control brings - sometimes leads to unethical and/or illegal behaviours. For example, Ali and co-authors find that when managers own Malaysian companies, these companies tend to experience more earnings management. ${ }^{45}$ Such findings probably also apply to state owners who also manage Malaysian companies. For their part, Munir and co-authors show that related party transactions negatively associate with firm performance. Clearly, untoward behaviour explains such a relationship - as family firms exhibit stronger losses related to such transactions than non-family firms. ${ }^{46}$ When these studies are taken together, they point to state and family related party transactions that probably decrease firm value through distortionary, preferential trading and finance decisions. Other authors have gone further to argue that common ownership and control has led to state-supported "cronyism.,"47

Such "cronyism” clearly has affected Malaysia firms' finance in the past. Authors like Faccio have found evidence, with reference to Malaysia, that banks tend to allocate capital to politically connected firms - the very definition of anticompetitive behaviour. ${ }^{48}$ Previous forced bank mergers have favoured the politically connected - also favouring anti-competitive behaviour. ${ }^{49}$ Figure 15 illustrates the likely distortionary (if not anticompetitive) nature of state

\footnotetext{
${ }^{45}$ See Salsiah Ali, Norman Salleh and Mohamat Hassan, Ownership Structure and Earnings Management in Malaysian Listed Companies: The Size Effect, 1 ASIAN J. OF Bus. AND ACCOUnT. 2, 2008, available online.

${ }^{46}$ See Sa'adiah Munir and Reza Jashen Gul, Related Party Transactions, Family Firms and Firm Performance: Some Malaysian Evidence, Finance and Corporate Governance Conference 2011 Paper, 2010, available online.

${ }^{47}$ See Simon Johnson and Todd Mitton, Cronyism and capital controls: Evidence from Malaysia, 67

J. OF FIN. ECON. 2, 2003.

${ }^{48}$ See Mara Faccio, Politically Connected Firms, 96 AMER. ECON. REV. 1, 2006, available online.

${ }^{49}$ See Beng-Soon Chong, Ming-Hua Liu, and Kok-Hui Tan, The wealth effect of forced bank mergers and cronyism, 30 J. OF BANK. \& FIN. 11, 2006, available online.
} 
participation in Malaysia's economy and its effects on bank lending. Malaysian firms owned by the government had higher leverage (meaning more bank credit), larger asset sizes (assets bought with more equity, debt or revenue) but lower share premia than non-government owned companies. Higher borrowing, combined with lower valuations, suggests that shareholders do not think these firms got more credit than they deserve/need. Firms with political connections also had higher leverage. However, their share premia exceeded those of firms without such connections. Investors clearly value politically connected Malaysian firms for the likely advantages (funding, sales and other) such connections afford.

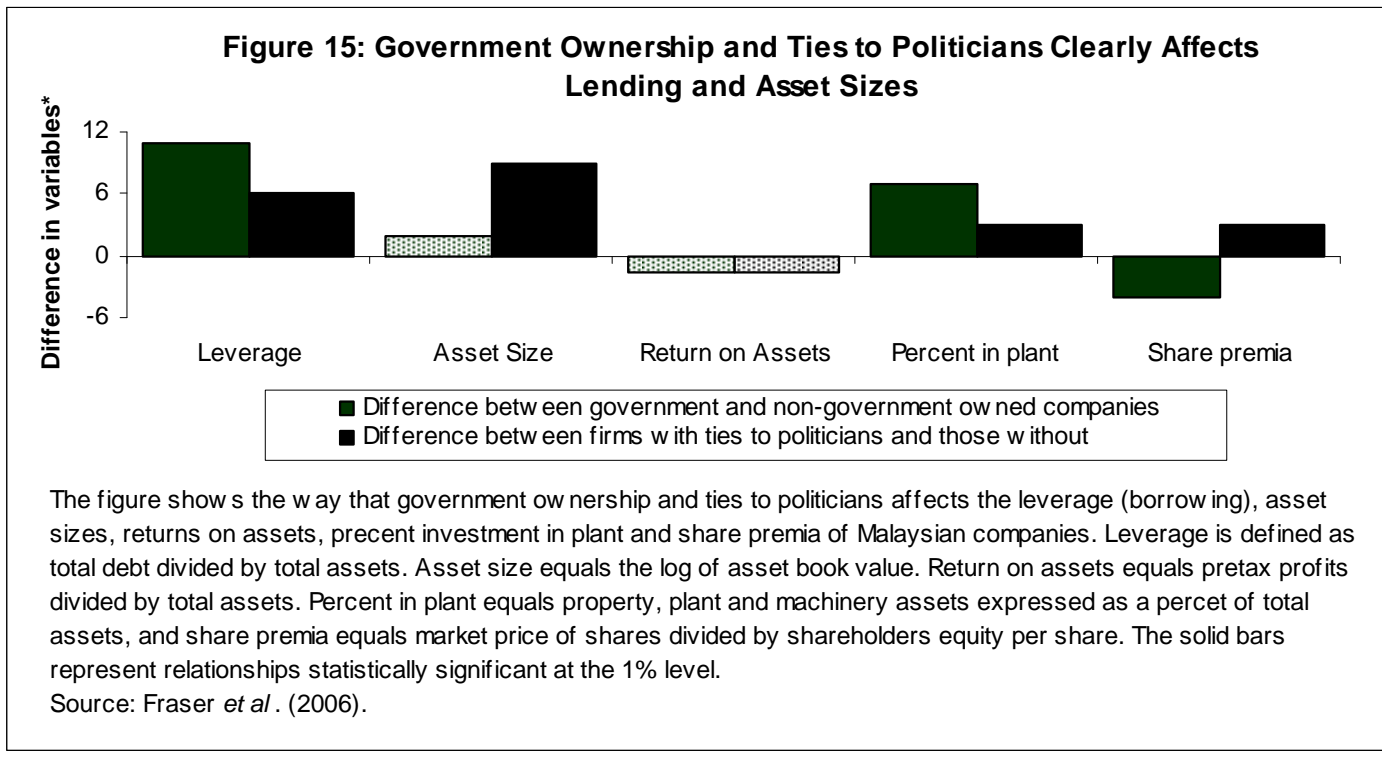

What do these data mean for bank compliance and audit staff interested in the potential enforcement of Malaysia's competition law? If political and family connections really do increase the risk of anticompetitive behaviour, then auditors need to assess the risks that such anticompetitive behaviour (or perceived anticompetitive behaviour) may pose to their employers’ banks. Figure 16illustrates some of the implications for internal auditors of anticompetitive behaviour driven by common government, political or family control. ${ }^{50}$ We present many of the actions bank management and auditors can take now, offering justification for any of these actions in subsequent sections.

\footnotetext{
${ }^{50}$ We assume that such political connections and state ownership do not distort the incentives of internal auditors. Empirical evidence finds higher audit fees charged for politically connected firms than for unconnected firms. See Effiezal Wahab, Mazlina Zain, Kieran James, and Hasnah Haron, Institutional investors, political connection and audit quality in Malaysia, 22 ACC. RES. J. 2, 2009.
} 
Figure 16: What do the anticompetitive incentives related to government and family ownership mean for antitrust risk controls and the audit of Malaysia's financial firms?

If you believe the literature (that government and family control of company groups) raises the risk of anticompetitive behaviour, several implications follow. Companies under government or family control need to put in more controls to prevent, detect and punish anticompetitive behaviour. Auditors need to keep the results of this literature in mind as they assess risks and look for harmful conduct.

\section{For bank directors:}

- make statements in public about any warnings, investigations, or questionings by Bank Negara or the Competition Commission as a way of helping the entire industry assess the likelihood of future enforcement in this area,

- have explicit signoff by compliance or risk management group when dealing with clients (or prospects) under common ownership,

- start a hotline, where customers can complain about perceived anticompetitive behaviour BEFORE they take it to the Competition Commission,

- put the rationale for major competitive decisions related to lending practices in writing, making reference to the market-driven reason for the move,

- when writing up the rationale for commercial decisions, have a space on the confidential write-up form called "antitrust issues," where the writer describes what he or she did to consider the antitrust aspects of the decision - and what he or she found.

\section{For auditors:}

- decide every year when creating the risk-based annual audit plan if the risk of Competition Commission investigation warrants an antitrust internal audit,

- decide if state ownership/control, political connections and family control increase or decrease the likelihood of Competition Commission investigation, ${ }^{*}$

- monitor the press for investigations as way of deciding on risk levels (during annual planning) and thus if controls are adequate (during an engagement),

- focus on parts of the business outside Malaysia (or with effects outside of Malaysia),

- include the risk of private lawsuits (rights of private action) as well as Competition Commission enforcement when analysing antitrust risk.

* The literature produces ambivalent results related to the effect of state ownership and political connections on the likelihood of Competition Commission investigation. On the one hand, the probability of anticompetitive behaviour may increase. On the other hand, such connectedness may help shield companies from Commission oversight.

Source: authors.

\section{Malaysian Competition Commission Scrutiny Probably Will Not Have a Significant Effect}

At first glance, Malaysian law clearly prohibits the anti-competitive behaviour we showed occurred in the US and EU as a "concerted practice." 51 The range of practices we reviewed above in other countries tends to fall under only two provisions in the Competition Act - restrictions on horizontal and vertical

\footnotetext{
${ }^{51}$ Competition Act, Act 712, 2010, at 2, available online.
} 
agreements and abuse of market power. ${ }^{52}$ Under Malaysian law, banking and securities brokering do not fall into any of the exemptions explicitly listed in the Competition Act. ${ }^{53}$ The2013 Financial Services Act further specifically mentions "prohibited business conduct" which includes anticompetitive behaviour. ${ }^{54}$ Both statutes thus clearly and specifically apply Malaysia's competition regime to financial services - leaving little doubt about the legislature's intent to apply the country's antitrust laws to financial services. If these provisions mean anything at all, Malaysia's financial institutions should start preparing for the same kind of antitrust regime operating in other jurisdictions like the US and EU.

However, a number of factors suggest that the Malaysian competition regime will probably not operate like those of other countries in the short to medium term. The relationship between provisions in the Competition Act and Financial Markets Act represents one of those factors. Notably, courts might take a limited view of anticompetitive behaviour to cover only behaviours mentioned in Schedule 7 of the 2013 Financial Services Act. ${ }^{55}$ Such conduct includes "exerting undue pressure on, or coercing, a financial consumer to acquire any financial service or product as a condition for acquiring another financial service or product." 56 Such conduct also includes "colluding with any other person to fix or control the features or terms of any financial service or product to the detriment of any financial consumer, except for any tariff or premium rates or policy terms which have been approved by the Bank." 57 Such behaviour leaves out many aspects of the illegal formation of horizontal and vertical agreement and abuse of market power mentioned in the Competition Act. However, such an interpretation is unlikely - as legislators could have simply added an exemption for financial services directly in the Competition Act. However, if politics and other factors are able to sway judicial interpretation, we must allow for such a possibility.

Even assuming that the broader provisions of the Competition Act apply (rather than the restrictive conditions mentioned in the Financial Services Act), we still do not know the extent to which actual anticompetitive behaviour in the financial services sector would infringe on the Competition Act. In other words, do the prohibitions in the Competition Act outlaw the actual anticompetitive behaviour that most regulators seek to prevent and/or punish?

\footnotetext{
${ }^{52} I d$ at chap 1 and 2 respectively.

${ }^{53}$ Exempted sectors, as mentioned in Schedule 1 of the Act, include the communications and energy sectors. Other exempted activities - as defined in art 3(4) -- include, charity and other social activities.

${ }^{54}$ Financial Services Act of 2013, at 124, available online. The article specifically requires that a, "financial service provider shall not engage in any prohibited business conduct set out in Schedule 7." Schedule 7, for its part, lists anticompetitive behaviours forbidden under the Financial Services Act.

${ }^{55}$ See Id at Schedule 7.

${ }^{5}$ Id at Schedule 7, art. 5.

${ }^{57} I d$ at art. 6.
} 
The Competition Act basically defines only two broad offences - anticompetitive horizontal and vertical agreements and abuse of a dominant position. Figure 17 shows the range of actual antitrust violations from the US which clever Competition Commission staff might shoehorn into each category. There is no guarantee that the Competition Commission will view all the offences we have binned into the broad categories listed in the figure as infractions in Malaysia. In other words, the Competition Commission might not view activities which are anti-trust violations in the US or EU as infractions under Chapter 1 and Chapter 2 of the Malaysian Competition Act. ${ }^{58}$ Much will depend on the, as yet, unwritten Guidance that will ultimately aid the communities understanding of what the Commission considers to be unlawful. As such, the range of activities that bank managers should control for, and that internal auditors should audit for, remains uncertain.

\title{
Figure 17: Do the Competition Act's Broad Labels Really Criminalise the Panoply of Anti-Competitive Behaviours Likely to Occur in the Malaysian Financial Services Sectors?
}

\author{
Malaysian law \\ Foreign law \\ Prohibition on \\ Cartel agreements, restrictive practices, exclusive dealing, price fixing, bid \\ horizontal and \\ rigging, market sharing, group boycotts, restraints of trade, tacit collusion, \\ vertical agreements \\ vertical restraints, resale price maintenance, unilateral policies, "excessive" \\ horizontal integration, “excessive” vertical integration, price \\ discrimination, and tying. \\ Prohibition on abuse \\ monopolisation, abuse of a dominant position, predatory pricing. \\ of dominant position \\ Source: authors (based on Graham and Richardson, 1997).
}

Even assuming that the current legislation completely and adequately covers the anticompetitive behaviour the Parliament targeted, we have no guarantee that the financial services sector would not qualify for a block exemption in the future. ${ }^{59}$ Financial service firms could apply for a block exemption - hoping to carve out such an exemption that would let them engage in legal anticompetitive behaviour in the future. ${ }^{60}$ Moreover (and even less likely) individual banks may apply to the Competition Commission for individual exemptions. ${ }^{61}$

Malaysian banks may seek - with highly unlikely prospects of success - to use the Act's defences in cases to defend already existing anticompetitive behaviour that is

\footnotetext{
${ }^{58}$ A particular cause for difference between regulators' views about anticompetitive behaviour might come from differences in the application of Malaysian (versus US and EU law). Malaysian law focuses on the conduct - whereas US and EU law make much more allowance for anticompetitive effect. Basically, the Competition Act makes unlawful any horizontal agreement between firms seeking to fix prices, share markets, limit control of economic factors of production or rig bids (as automatically having the object to restrict competition). See Competition Act at s.4(2).

${ }^{59} I d$ at art. 8.

${ }^{60}$ Such block exemptions for financial services do not receive wide support from the European Commission. However, suspensions of EU antitrust law (in the form of block exemptions) have been given in relation to state aid to banks and other financial service providers during the financial crisis.

${ }^{61} I d$ at s. 6.
} 
prohibited by section 4 of the Act. In particular, the Competition Act allows for an enterprise to be relieved of its liability under section 4 if "there are significant identifiable, technological, efficiency or social benefits directly arising from the agreement [that the enterprise is a party to]”. ${ }^{62}$ Figure 18 shows the conditions under which anticompetitive behaviour may escape liability. One could easily imagine a bank (or banking association) arguing - with an unlikely chance of success -- that most if not all banking activity exhibits all four features presented in the figure. ${ }^{63}$ Indeed, a number of countries have previously exempted financial services from antitrust enforcement on public policy grounds. ${ }^{64}$ A recent UNCTAD report notes that, "although in many jurisdictions financial institutions are completely exempted from the purview of competition legislation on the grounds of 'systemic stability' or the 'specialized nature of the industry', there are no sound economic reasons for doing so. Given the central role played by financial intermediation, savings and investment in the economic development process, it is important to ensure a competitive financial services industry." ${ }^{65}$ As such, the possibility of exempting the financial services sector, in whole or in part, from the Competition Act entirely makes the task of an internal audit of application of antitrust rules to Malaysian banks difficult. ${ }^{66}$

\section{Figure 18: Malaysian Financial Services Getting Ready for a Bloc Exemption?}

Requirement for exemption

There are significant identifiable

technological, efficiency or social benefits

directly arising from the agreement;

The benefits could not reasonably have been provided by the parties to the agreement without the agreement having the effect of preventing, restricting or distorting competition;

The detrimental effect of the agreement on competition is proportionate to the
Possible argument

The Competition Act will lower profitability too much. Competition reduces profits which go toward Malaysian banks' capitalisation, liquidity, and incentive to save costs, create new products and so forth.

Restrictions of competition provide the easiest and most transparent way of promoting banking stability - as other arrangements (like providing emergency funding, using monetary policy and so forth) are more expensive and less certain. As the 2008 crisis showed, banking stability can help the entire economy. Anti-competitive behaviour only

\footnotetext{
${ }^{62} I d$ at s. 5 . The conditions in section 5 relate to a series of conditions often found in antitrust legislation which promote consumer welfare and technological innovation. We describe these conditions in more detail in the figure mentioned in the text.

${ }^{63}$ Section 5 identifies the conditions under which banks may seek exemption from the Act either as a group or as individuals. Section 6 describes the conditions for seeking relief from a Competition Commission enforcement action as an individual entity. Section 8 and 9 describe the conditions under which banks may seek relief as a group.

${ }^{64}$ Dauboin provides an interesting description of France's exemption of financial services from its own antitrust rules and compares with the US. Naturally, EU antitrust law continues to apply. See Adeline Dauboin, The Application of Antitrust Law to Banking and Financial Companies, In Martin Rogoff, THE FINANCIAL CRISIS OF 2008: FRENCH AND AMERICAN RESPONSES, available online. ${ }^{65}$ ShyamKhemani, Application of Competition Law: Exemptions and Exceptions, 2002, available online. at p. 31 .

${ }^{66}$ Admittedly, this represents self-induced uncertainty. Representatives of the banking sector would need to apply for such an exemption, with some banks likely taking a passive or non-existent role in militating for the exemption.
} 
benefits provided; and

The agreement does not allow the enterprise concerned to eliminate competition completely in respect of a substantial part of the goods or services. impacts on a few, and only causes consumers to become slightly poorer.

Setting price, quantity and even quality restrictions collectively (by the bank association for example) still allows for market entry, stealing market share and so forth.

Source: Malaysian Competition Act at Section5 (with analysis by authors).

Uncertainty about the application of subsidiary regulation creates almost as much uncertainty for Malaysia's banks and financial firms as unpredictability about the types of offences and organisations covered. Which government body holds the competencies for antitrust rulemaking for financial firms in Malaysia? At least three agencies have the power to draft competition-related regulations affecting banks. First, the Bank Negara can "issue guidance in writing on (a) descriptions of conduct which amount to [anticompetitive behaviour] and/or (b) factors that are to be taken into account in determining whether a financial service provider has engaged in [anticompetitive behaviour]." 67 Such guidance "shall be issued in consultation with the Competition Commission."68 Second, the Minister of Domestic Trade and Consumer Affairs may pass regulations which "giv[es] full effect to the provisions..., carr[ies] out or achiev[es] the objects and purposes... and provid[es] for any supplemental, incidental or consequential matters in relation to this Act."69 Third, the Competition Commission (of course) "may issue and publish such guidelines as may be expedient or necessary for the better carrying out of the provisions of [the Competition Act]." 70 At first glance, primary legislation does not assign supremacy or primary responsibility with any one of these agencies. ${ }^{71}$ The presence of multiple potential regulators - and questions about jurisdictional overlaps between them -makes the creation and audit of antitrust rules inside Malaysian banks difficult. Without going too far off topic, we provide a draft Memorandum of Understanding between the Bank Negara and the Competition

\footnotetext{
${ }^{67}$ Financial Services Act, s.124(2). We have replaced "any prohibited business conduct set out in Schedule 7" in the original with the phrase "anticompetitive behaviour," as this relates to the anticompetitive behaviour mentioned in Schedule 7.

${ }^{68}$ Financial Services Act at s.124(3), underlining ours. We take "shall” to mean an imperative like "must." However, given that the powers of the Commission to refuse such rulemaking does not appear in the Act, such a "shall” probably represents "should" in practice.

${ }^{69}$ Competition Act at s.65(1). We have removed the lettered-list formatting in the original for readability.

${ }^{70}$ Competition Act at s.66(1). Interestingly, the use of the word (at least in the English version of the Act) "may" represents an conditional right. In contrast, the Financial Services Act (as we have noted above) imposes a definite obligation "shall” on the Bank Negara to make such rules. To our mind, this creates a hierarchy of obligations and administrative entitlement - with central bank rulemaking superseding the Competition Commission's.

${ }^{71}$ We have provided, in the previous footnote, an extremely flimsy basis for establishing the Bank Negara's supremacy over such rulemaking for the financial services sector. Whether the slight difference in "shall” versus "may” justifies assigning the Bank Negara with primary responsibility for such rulemaking or assigning it blame when/if such rulemaking fails to curb collusion and anticompetitive behaviour represents an entirely different matter.
} 
Commission in Appendix I to resolve this problem - and thus help internal auditors in Malaysia’s banks. ${ }^{72}$

In any case, from a risk-based perspective, the Competition Commission will have little interest in monitoring anticompetitive behaviour in banking, as a sub-sector of the wider financial services sector. Figure 19 shows the size (as measured by the value of financial assets) of the various types of Malaysian financial service sectors. Under a risk-based approach to antitrust monitoring and supervision, the Malaysian Competition Commission will allocate market review and investigation manpower and resources based on the probability of anticompetitive behaviour and the value of the harm any likely anti-competitive behaviour causes. ${ }^{73}$ As shown, equities' values eclipse other types of financial assets -- including loans and savings. Private credit does represent a fairly substantial part of GDP. However, given the size of the country's equity and debt markets, the Bank Negara (working with the Securities Commission) and the Competition Commission would - and should focus on securities and stock-brokers more than banks. Malaysian bank executives can rationally assume that the Competition Commission will place a low priority on detecting, investigating and sanctioning banking sector anticompetitive behaviour. $^{74}$

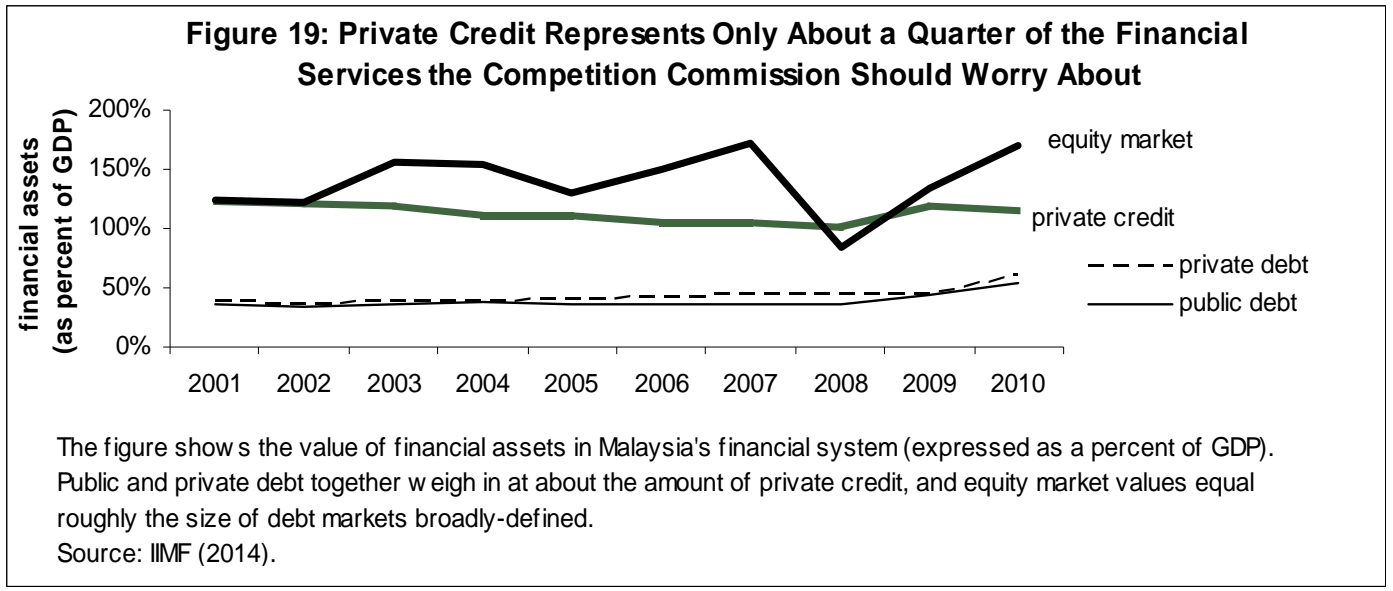

\footnotetext{
${ }^{72}$ Having greater regulatory clarity and certainty helps lower the costs and increase the effectiveness of internal audit. Having one rulemaking body reduces time searching for rules and reduces chances of conflicting rules which would make corporate anti-trust rules harder to write.

${ }^{73}$ Readers with an economics background will recognise that this means the Malaysian Competition Commission should maximise the "inter-temporal, probabilistic expected value" of gains from antitrust investigations and prosecutions. While the Commission probably won't run as neoclassical economists might like, such a paradigm still represents the best method companies can use to guess where the Commission will allocate its scarce supervisory and enforcement resources. See Eric Posner and Glen Weyl, Benefit-Cost Paradigms in Financial Regulation, UC COASE-SANDOR INST. FOR L. \& ECON. RES. 660, available online.

${ }^{74}$ We use the word "rationally" in the economic sense of the term. Rational behaviour, to an economist, means that the costs of engaging in large amounts of monitoring likely exceed the probability-weighted likely benefits of such monitoring. Thus, the Competition Commission should rationally engage in very little monitoring, catching only the cheapest, easiest to spot cases.
} 
Even if the Competition Commission wanted to detect anticompetitive behaviour among Malaysia's banking institutions, its staff's lack of quantitative skills probably makes the organisation unable to engage in serious oversight. A review of the Commission's staffing shows only one department even potentially capable of mining the data needed to spot anticompetitive behaviour. ${ }^{75}$ Lack of serious econometric studies conducted by the admittedly very young competition authority demonstrates such a lack of capacity - though its capacity may be enhanced in the future (see Figure 20). ${ }^{76}$ As we have previously mentioned, Commission officials have not made any statements in public (at least translated into English) about their interest in monitoring the financial sector. And the most relevant area affecting competition between Malaysia’s banks (mergers and merger control) remains unregulated. ${ }^{77}$ Given recent announcements that the government wishes to further encourage “consolidation” in Malaysia's banking sector, lack of focus on this highrisk area shows lack of interest in regulating anti-competitive behaviour among Malaysian banks. ${ }^{78}$ Malaysian bank directors -- and the internal auditors who work for them - may thus rationally assume that the Competition Commission will engage in little oversight of the banking sector for the foreseeable future.

\footnotetext{
${ }^{75}$ The Commission's website lists Komala Veeriah as the sole contact in the Commission's economics unit. His work in the public domain shows knowledge of quantitative methods - though not enough to do the kind of serious econometrics needed to detect anticompetitive behaviour in Malaysia’s banking system. Among Commission members themselves, only Prof. Hasnah Haron seems to have the quantitative background needed to understand the kinds of statistical methods needed.

${ }^{76}$ Publication of fancy econometric and data mining studies does not necessarily establish a competition agency's capacity - as many such agencies do not publish their market reviews. In the short term, the Malaysian Competition Commission could outsource such studies, much like the EU does. See EU DG-Competition, Interim Report II Current Accounts And Related Services: Sector Inquiry under Article 17 Regulation 1/2003, 2006, available online.

${ }^{77}$ The Competition Act makes no mention of merger control (leaving mergers and acquisitions unregulated by the Act) and the Commission has no specific department (of course) dealing with mergers.

${ }^{78}$ See Scott Hamilton, Malaysian Central Bank Governor Says Bank Mergers Would Be Good, BLOOMBERG, 1 July, 2011, available online.
} 


\section{Figure 20: Will Malaysia’s Competition Law Become More Effective Over Time?}

The Malaysian Competition Commission has not yet celebrated its fifth birthday. Can we expect the Commission will monitor and enforce antitrust law in/among Malaysia's financial institutions better than it does now? The evidence suggests yes. As shown in the figure, market power exercised by banks across countries tends to fall as more time passes since the adoption of that country's competition law. ${ }^{79}$ If Malaysia follows these crosscountry trends, the Competition Commission will need to operate 30 more years in order to witness a halving of the market power currently exercised by Malaysia's banks. ${ }^{80}$ Yet, this data give hope that the operation of a competition authority does correlate with greater banking sector competition.

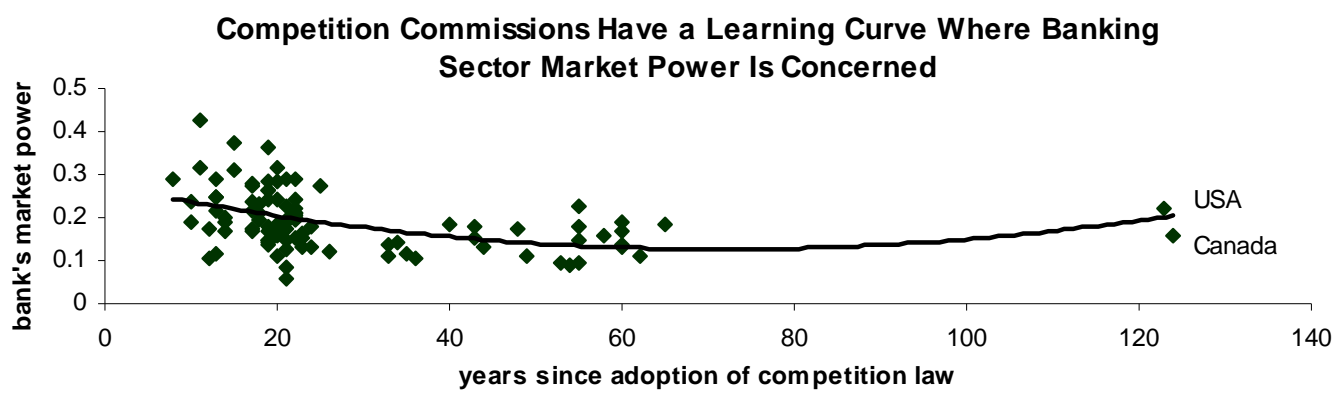

The figure show s the extent of a country's banks' market pow er (as measured by adjusted Lerner Indices) compared $w$ ith the number of years a competition law has been in force. We keep the US and Canada as outliers to show the relationnship betw een the vintage of a country's anti-trust laws and market pow er among its banking sector may not remain negative indefinitely.

Source: Kronthaler, 2007 (for years since adoption of anti-trust legislation) and Clerides and co-authors, 2013 (for market pow er among each country's banks)

Even if the Competition Commission manages to solve all these issues and obtain the econometric skills needed to detect anticompetitive behaviour among Malaysia's banks, the Price Control and Anti-Profiteering Act may cause banks to conceal evidence of possession or use of market power. ${ }^{81}$ The Price Control Act (for short) gives the Minister for Domestic Trade and Consumer Affairs the right to appoint a Price Controller who may set the price of "any services." 82 The Price Control Act also criminalises profiteering - or setting "profit unreasonably high.”83 The Minister for Domestic Trade and Consumer Affairs may use whatever criteria or method he or she pleases to determine if banks and other service providers earn

\footnotetext{
${ }^{79}$ See Franz Kronthaler, Effectiveness of Competition Law: A Panel Data Analysis, INST. FOR ECON. RES. DP, 2007, available online.

${ }^{80}$ We say "witness" because these data in no way necessarily imply causality. In other words, we can not be sure that market power exercised by each country's banks depends on the operation of that country's competition authority. To make such a conclusion, we would need to filter out (or "control for" in the language of economics) the effects of banking regulations, macroeconomic factors, and a range of other factors.

${ }^{81}$ See Price Control and Anti-Profiteering Act 2011, Act 723, available online.

${ }^{82} I d$ at art. 5(a).

${ }^{83} \mathrm{Id}$ at $14(2)$.
} 
exceedingly high profits. ${ }^{84}$ Such a legal provision provides to banks an extremely strong incentive to hide profits to avoid attracting attention and potential sanctions under the profiteering rules. In other words, Malaysian banks have strong incentives to develop and use market power to obtain profits -- which they then need to hide through various accounting, spending and other programmes. Such concealment makes the detection of anticompetitive behaviour using econometric and statistical methods even more difficult. As such, the Price Control and Anti-Profiteering Act is likely to contribute to anticompetitive behaviour rather than reduce it.

All these factors mean three things for internal auditors. First, bank managers (and thus internal auditors) will rationally put off adopting antitrust controls because they face legal uncertainty for the reasons we have just described. In particular, because of this uncertainty Malaysian bank managers will have little incentive to create their own internal rules which might (or might not) address the broad infractions defined in the Competition Act. Second, the Competition Commission (and to a lesser extent the Bank Negara) is highly unlikely to detect anticompetitive behaviour by banks in the next 5-10 years. Specifically, deficiencies in both the Commission's political will to enforce the Act and its ability to undertake serious econometric studies, in addition to the lack of present cases, means that anticompetitive behaviour will remain a low risk-of-detection and high rate of return proposition. Third, any serious work by banks to prevent and detect anticompetitive behaviour is made high-cost and low return as a result of the lack of work by the Government to provide toolkits, relevant information, and public data that competitors can use to sniff out perpetrators. Indeed, the lack of guidance and opinions by the Commission makes suggesting compliance standards or procedures, or undertaking any internal antitrust audit a risky task. ${ }^{85}$

\section{Detecting Anticompetitive Behaviour and Creating Antitrust Compliance Campaigns in Malaysia's Financial Services}

Econometric methods of detecting anticompetitive lending behaviour (as only one example of a range of areas of potential anticompetitive behaviour) in Malaysia's financial services sector should concern bank managers for three reasons. First, econometric methods can help pin-point collusion by mid-level managers or even the CEO without the knowledge of the banks' Board. Early detection using statistics can help prevent later complaints by consumers and rival banks. ${ }^{86}$ Second, such data can help spot anticompetitive behaviour among rivals. ${ }^{87}$ As Malaysia is likely

\footnotetext{
${ }^{84}$ Using the words of the Act itself, "the Minister shall prescribe the mechanism to determine that profit is unreasonably high.” Id at 15(1).

${ }^{85}$ See Rastan Loong and Cara Kararuddin, Challenges Lie Ahead for Malaysia's New Competition Commission, INT’L FIN. L. REV., 2012, available online.

${ }^{86}$ In the broader compliance and law enforcement literature, the question about statistical versus intelligence-based detection methods remains an open one.

${ }^{87}$ An interesting aside concerns whether the collection of such data can promote collusion rather than serve to discover the collusive behaviour of industry rivals. One-sided knowledge of rivals' pricing and production strategies can allow firms like banks to tacitly collude by setting prices and
} 
to follow the UK civil justice system's precedent, it will allow private rights of action by which bank managers can recoup losses arising from such rivals' anticompetitive behaviour through compensatory damages only (rather than to the extent possible with treble damages under the US system). ${ }^{88}$ Authors like Carletti et al., using data, identify unfair or discriminatory access conditions, partial data sharing, and regulatory barriers as problems in the EU context. ${ }^{89}$ They also identify increasingly high switching costs as a factor providing banks with significant market power. Malaysian banks might benefit from Carletti-like studies. Third, bank managers can use such data to argue for or against particular competition policies. In Italy for example, bank managers used comparative data about the cost of opening an account as a way to argue for pro-competitive policies. ${ }^{90}$

What are some of the data that bank managers and compliance officers could use to their bank's benefit? Figure 21 provides examples of some of the data that could be obtained - and ideas on ways in which this data might be used. Data about lending, revenue earning from such lending - and patterns across time and across banks -can provide bank managers and auditors with information they need to detect anticompetitive behaviour in their own institution, spot anticompetitive behaviour by rivals, and militate for competition policy change.

\section{Figure 21: Publicly Available Variables and Use in Spotting Anti-Competitive Behaviour}

\footnotetext{
Variable Use

Value of loans

Use in identifying whether lending decreases or increases strategically across banks

Net interest Use to compare with value of loans (as we do below) across banks to see if revenue any serial correlation

Interest income on loans Useful when comparing with the value of loans, looking at changes over time, and correlating with factors that may signal collusion or abuse of market power.

Residential This data can be used to comparebetween banks and monitor volumes of Mortgage Loans these loans relative to others (like consumer, retail, and corporate/commercial loans) to detect sub-sector specific anti-competitive behaviour.

Number of investigations Useful as dependent variable to figure out what lending and interest earning behaviour has correlated with anticompetitive behaviour in the past.

quantities which maximise profits. See Anthony Dennis, Assessing The Risks of Competitive Intelligence Activities Under The Antitrust Laws, 46 S.C. L. REV. 263, 1995.

${ }^{88}$ Unfortunately Malaysian courts will probably not award large damages to antitrust litigants in the near future. By awarding very large awards, Malaysian courts can help provide incentives for firms to police markets far more effectively than the cash-strapped Competition Commission ever could.

${ }^{89}$ See Elena Carletti, Giancarlo Spagnolo, ,StefanoCaiazza, and CaterinaGiannetti, Banking Competition in Europe: Antitrust Authorities at Work in the Wake of the Financial Crisis, 33 WoRLD COMP L \& ECON. REV. 4, 2010, available online.

${ }^{90}$ In the current Malaysian policymaking environment, the Competition Commission and Government will not undertake their own studies to assess the extent to which competition-related policies help or hurt business. Banks' own research can help fill this gap. For an example of such a study (from a research institution), see Luigi Guiso, Paola Sapienza, Luigi Zingales, The Cost of Banking Regulation, NBER WORKING PAPER NO. 12501, 2006.
} 
Net loans The difference between gross and net lending may signal anticompetitive behaviour (as lenders may write loans they intend to cancel or have quick repayment in order to puff up the supposed value of lending).

Repo volume Banks may use data about repo levels to particular banks as a signal of current or future lending.

Share Useful in determining statistically if a particular ownership pattern correlates

government/family with lending and/or profit trends, suggesting collusion-inducing ownership communication

Source: variables provided by Bankscope with explanations provided by authors.

Suspicious patterns in data can provide insight about both legal and illegal methods of competing in Malaysia's banking sector. Figure 22 shows, one example of an interesting trend in the data that may further investigation by bank managers and internal auditors to establish the existence of anticompetitive activities. The figure shows the relationship between the amount of interest banks earn and the profit margin on that interest. Interestingly, the more the largest Malaysian banks earn, the higher their profit margins. Size in lending represents an important predictor of lending profitability in Malaysia. Of these banks, CIMB Group Holding represents the one to watch - with loan yields at least 100 basis points above the others. Such data does not imply definite anticompetitive behaviour. They just tell auditors and others that this is an anomaly that is worthy of further investigation. ${ }^{91}$

${ }^{91}$ Of such lending, commercial lending (commercial loans) represents both the highest risk of anticompetitive capital allocation and the largest part of Malaysian banks' lending portfolios. On average, they made up $36 \%$ of all loan types - compared with $24 \%$ for residential mortgages and $28 \%$ for consumer loans. 
Figure 22: Suspiciously, Larger Lending Portfolios Mean MORE Profits
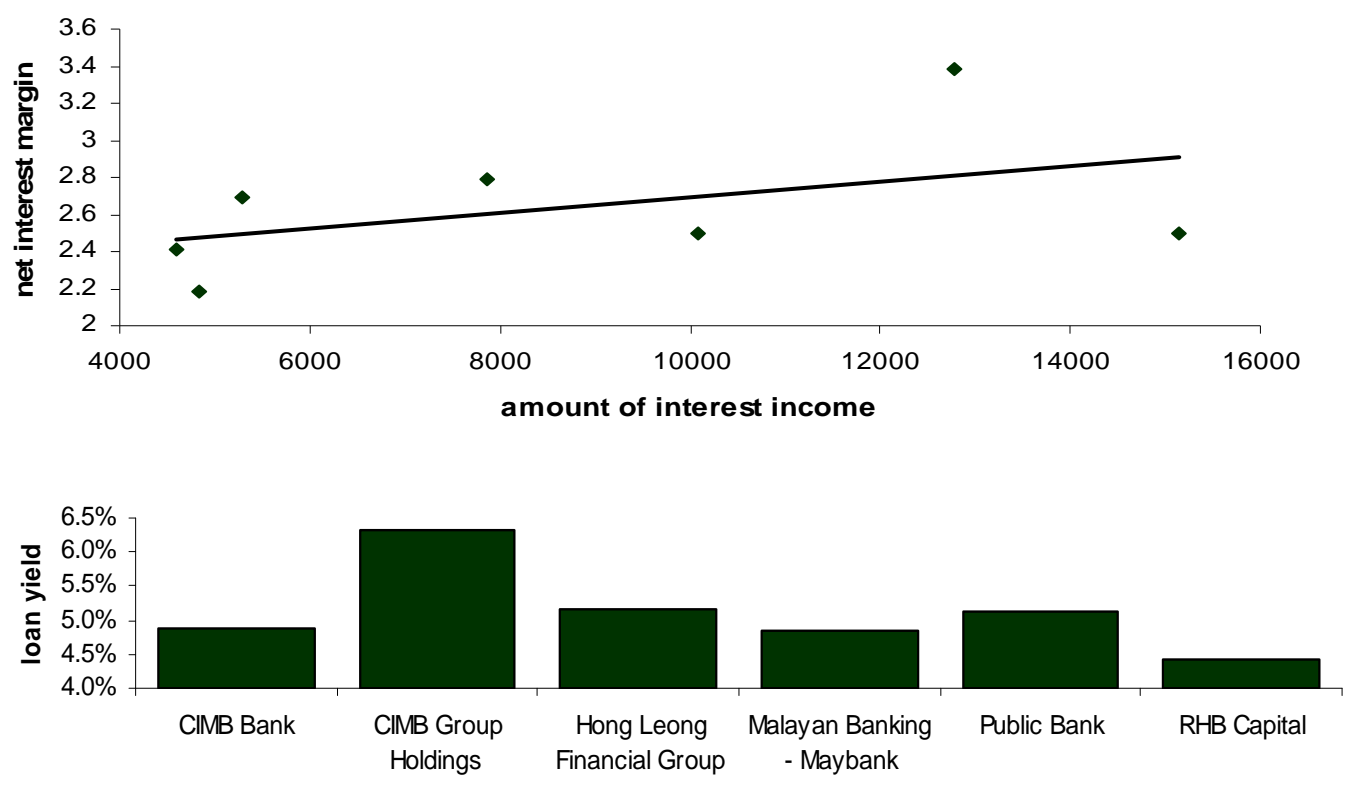

The data in the figure show the relationship between interest income amounts and net interest margins. The relatively strong positive relationship suggests size matters in lending in Malaysia. The bottom panel shows interest income as a percent of the total value of loans for the banks indicated. Source: WRDS (2014).

Looking at company data can reveal as many insightful patterns as looking at banks' data. Figure 23 shows interest-to-revenue ratios (expressed in basis points) for Malaysian companies in 2012. ${ }^{92}$ Malaysian company borrowing in any particular sector will depend on that company's growth prospects, previous revenues, interest rates and a host of other factors. However, companies' interest payments which fall significantly outside those of its peers can suggest who might be a victim or beneficiary of anticompetitive bank behaviour. Excessively high interest payments may mean that the company has too easy access to bank loans (if the company wants to gorge itself on cheap capital). Or such high interest payments may mean the company has too restricted access to capital (as its borrowing terms are more onerous than its peers). The same considerations apply when interest payments - as a percentage of the company's revenues - are too low. The actual level of these interest payments tells us far less than how they compare to peers. In the figure, we see that the industrial company grouping tends to have some companies with exceedingly high interest payments.

\footnotetext{
${ }^{92}$ We express these ratios in basis point terms so we do not have data which looks like 0.002, 0.102 and so forth. One hundred basis points equals $1 \%$-- meaning that the " 10 " on the vertical axis represents an income-payment-to-company-revenue ratio of $0.1 \%$.
} 


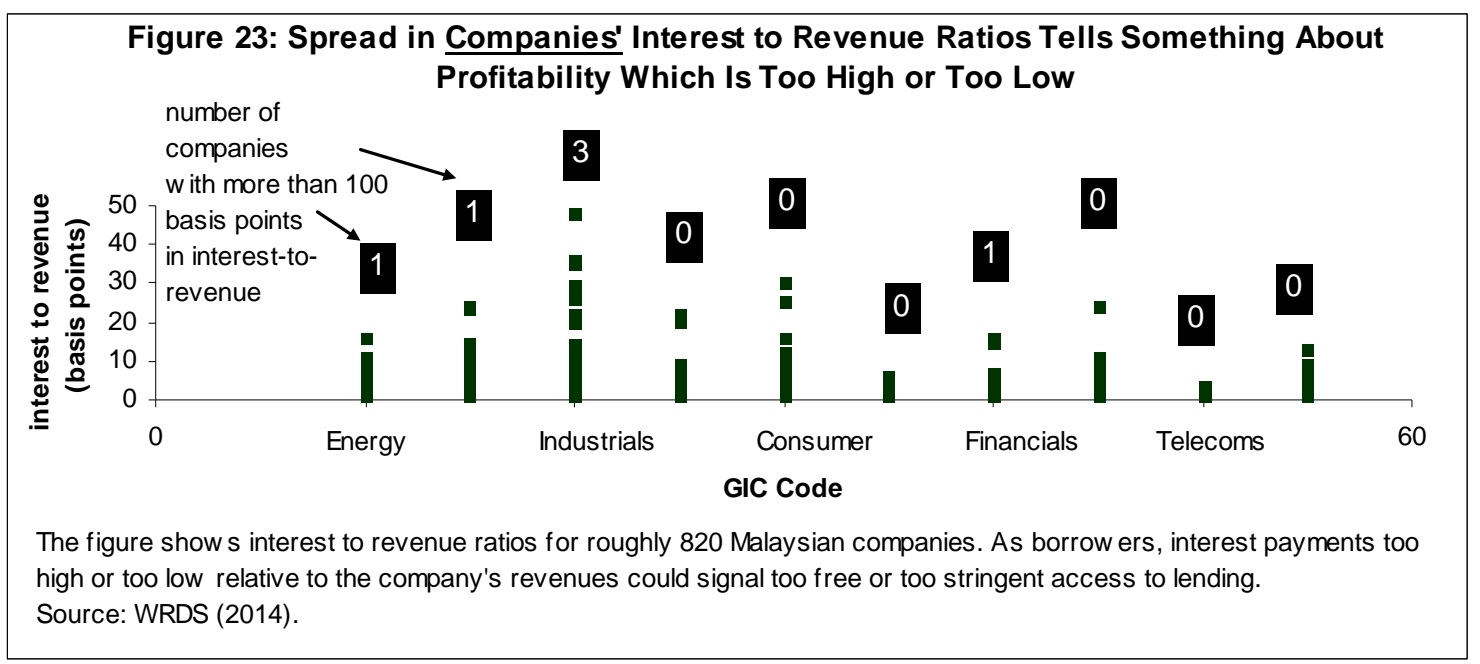

What do these differences imply about internal audit strategy? A wide range of "toolkits" can help bank managers and internal auditors prevent, detect and repress anticompetitive behaviour. ${ }^{93}$ Figure 24 describes some of the ways internal auditors can react when their bank sits at one of the extremes we have described ${ }^{94}$ Auditors need to define risks of anticompetitive behaviour in the bank and assess the extent to which various actions can help reduce the risk of government or competitor action costing the bank money. ${ }^{95}$

\footnotetext{
${ }_{93}^{93}$ For one such toolkit, see ICC, THE ICC ANTITRUST COMPLIANCE TOOLKIT, 2013, available online. ${ }^{94}$ Most of the law firm advice self-servingly assumes that more-compliance-is-better, ignoring the fact that antitrust compliance programmes should focus on specifically, empirically identified risks. SeeKiran Desai, Antitrust compliance programmes, MAYER, Brown, RowE\& MAW CliENT BRIEFING, available online.

${ }^{95}$ For an example of the way probability assessments can be used in deciding on firm or court mandated antitrust-related remedies, seeYavarBathaee, Developing an Antitrust Injury Requirement for Injunctive Relief that Reflects the Probability of Anticompetitive Harm,13 FORDHAM J. CORP. \& Fin. L. 329, 2008.
} 
Figure 24: Being Too Similar or Different Doesn't Mean Anti-Competitive Behaviour, But Should be Explainable

We have described several ways of statistically detecting when a financial firm may have access to relationships or size advantages which give it market power. Not all market power is illegal. However, market power (or obvious lack of such power) raises red flags which may attract regulators' attention. What should Malaysian bank managers do when they fall into the "too similar or too different" camp for market-related reasons which they can not obviously explain?

1. conduct a risk-based antitrust audit - differences may actually stem from anticompetitive behaviour of the bank's agents (employees and managers). Antitrust risk is defined as the probability of illegal behaviour multiplied by the value of the potential gain (or harm to consumers). Internal audit staff can help define this risk more clearly.

2. review bundled services - tying in financial services has become an areas of intense recent academic and policymaker interest. Bank managers can ask whether selling certain types of services together gives the bank a perceived unfair advantage.

3. start an internal investigation - investigations can range in formality, from curious questions to formal questioning in the presence of the employee's legal counsel. Such investigations provide far more information than statistical analysis. They may also seriously damage the internal auditor's attempts to foster a constructive antitrust environment.

4. start/strengthen a whistleblowing programme - perhaps one the cheapest and most effective measures a bank can take. Such work can encourage employees (agents) to speak up with financial rewards or other incentives.

5. review blog chatter for complaints - aggrieved customers can complain on their social media accounts about anticompetitive behaviour. Competitive intelligence software can help alert bank managers and internal auditors to issues before they come to the attention of regulators and competitors.

Several other actions (as briefly mentioned in the figure) can also help address the potential red flags for anticompetitive behaviour raised by statistical analysis. Malaysian bank managers can review their bundled services (like offering loans and selling loan insurance at the same time). ${ }^{96}$ Internal investigations (both exploratory and specifically focused on suspected illegal anticompetitive behaviour) can also help detect and stop such behaviour before the Competition Commission and/or

\footnotetext{
${ }^{96}$ The line between legal "bundling" and illegal "tying" remains fuzzy, for banks as well as those who regulate them. For a brief discussion of the issues from North America, see Carolyn Naiman and Jason Brooks, Are Canadian Banks Fit to Be Tied?CAN. Comp. Rec. 2004. See also, US Office of the Comptroller of the Currency, Today's Credit Markets, Relationship Banking, and Tying, 2003, available online.
} 
competitors can take action. ${ }^{97}$ Monitoring regular and social media also provides Malaysian bank managers with advanced warning from the public about dissatisfaction with aspects of the banks' behaviour that may later attract antitrust attention. $^{98}$

Whistleblowing programmes within Malaysian banks represent one of the most potentially important initiatives banks' management can take to detect and stop anticompetitive behaviour. ${ }^{99}$ Under whistleblower programmes, Malaysian bank employees and managers could complain internally about anticompetitive behaviour by the bank. Both the economics and legal literature supports antitrust whistleblower programmes. In the economics literature, whistleblower programmes have been shown to reduce the probability of collusion, decrease rents, and even decrease the expected fines for firms found guilty of collusion. ${ }^{100}$ Whistleblowing programmes which reward whistleblowers with cash, prestige, job advancement and other perks provide "negative fines" - strongly increasing the probability of detection of, and punishment for, anticompetitive behaviour. ${ }^{101}$ In the law literature, the recent passage of the US Criminal Antitrust Anti-Retaliation Act of 2013 shows that the US legal and political community favours the protection of persons who blow the whistle on anticompetitive behaviour within their firms. ${ }^{102}$

Malaysian law provides the legislative framework for the operation of antitrust whistleblower programmes in Malaysian banks. The Competition Act provides protection for whistleblowers - only in the specific case of making a complaint to the Competition Commission or helping with the making of such a complaint. ${ }^{103}$ Specifically, the Act prohibits coercing (or attempting to coerce) persons from reporting to the Competition Commission or assisting with Competition Commission investigations. ${ }^{104}$ Such protections only apply in case the whistleblower goes to the Competition Commission. Moreover, the Whistleblower Protection Act of 2010 provides for the whistleblower's identity to remain confidential to the public, his or her immunity from civil and criminal action, and

\footnotetext{
${ }^{97}$ For a US perspective and how-to manual on such internal investigations, see ABA, ANTITRUST COMPLIANCE: PERSPECTIVES AND RESOURCES FOR CORPORATE COUNSELORS, 2005.

${ }^{98}$ For a review of competition cases appearing in the Malaysian popular press, see Cassey Lee, Competition Law Enforcement in Malaysia: Some Recent Developments, ERIA-DP-2014-02, 2014, available online. For a recent example concerning financial services, seeAzli Jamil, Agents cry foul over EMGS-AXA link-up, FMT NEWS, March 27, 2013, available online.

${ }^{99}$ Potentially because not everyone thinks whistleblowing will work - particularly in Malaysia. See David Lehmann, Whistleblowing won't work in Malaysia, DELOITTE MYINSIGHT, available online.

${ }^{100}$ See Giancarlo Spagnolo, Optimal Fines in the Era of Whistleblowers. Should Price Fixers still Go to Prison? In Johan Stennek (ed.) The Political ECONOMY OF ANTITRUst, 2007.

101 See Maria Bigoni, Sven-Olof Fridolfsson, Chloé Le Coq and Giancarlo Spagnolo, Fines, Leniency and Rewards in Antitrust: An Experiment, CEPR DP7417, 2009.

${ }^{102}$ See Layne Kruse, Carlos Rainer, and Aubrey Stock, Criminal Antitrust Anti-Retaliation Act of 2013, Norton Rose Fulbright BRIEFING, 2013, available online.

${ }^{103}$ Competition Act s. 34.

${ }^{104}$ Id at 34(1) for the substantive provisions of the protection and 34(3) for the definition of types of whistleblowing and collaboration with the Commission. Article 34(2) - for its part - provides a nonexhaustive list of the types of coercion prohibited under the Act.
} 
protection against retaliation by law enforcement agencies. ${ }^{105}$ As discussed in Figure 25, other legislation allows whistleblowers to approach government agencies. However, Malaysian law provides few incentives for whistleblowers - like internal auditors - to approach management directly with their concerns. ${ }^{106}$

\section{Figure 25: How Poor Whistleblower Protection Law in Malaysia Discourages Internal Auditors from Informing Managers About Anticompetitive Behaviour During Audit Engagements}

Suppose an audit team have discovered a weakness in the Malaysian bank client which tolerates or promotes anticompetitive behaviour. The audit team makes recommendations to address the issues discovered, and thereby decrease the risk of investigation by the Competition Commission. Subsequently, the team is, made aware that higher management wishes the matter to be dropped and that no mention of the discovered behaviour should be included in the internal audit report. What are the legal consequences?

Unfortunately, Malaysian law gives little effective protection to whistleblowers using internal channels. The Whistleblower Protection Act provides protection for auditors who inform the police. ${ }^{107}$ The Companies Act and Capital Services Act allow potential whistleblowers to inform the Companies Registrar. If the company (bank) has acceded to the Bursa Malaysia's Corporate Governance Guide, the company may have included whistleblowing policies into company code of conduct or employment handbook. Dismissing an internal auditor (or other employee) for whistleblowing may then amount to breach of contract. Moreover, under the Industrial Relations Act, termination of employment as a retaliatory measure for whistleblowing may represent a breach of employment (due to the provisions of the Act itself).

In any case, few remedies exist for whistleblowers intending to approach employers with concerns about anticompetitive behaviour. Internal auditors and other employees looking to protect themselves will need to convince a Malaysian court that some breach of contract has occurred - a difficult and uncertain task at best.

Source: based on Tan and Ong (2011).

What effect would antitrust whistleblower programmes have in Malaysia's banks if local laws provided adequate incentives? We cannot know for sure - as the research only provides subjective evidence about the likely effect on such managers and internal auditors. Figure 26 shows the results of several studies of Malaysian

\footnotetext{
${ }^{105}$ Whistleblower Protection Act 2010, Act 711, s. 7(1), available online.

106 To complicate matters further, if the whistleblower is an internal auditor, he has a professional duty to report and leave the concern with the company’s management under Standard 2060 and Practice Advisory 2060-1. Practice Advisory 2440-2 (Communicating Sensitive Information Within and Outside the Chain of Command) basically encourages internal auditors to do the right thing keeping sensitive communications within the organisation, unless "legal or regulatory imperative, or a professional or ethical obligation, requires further action.” See Institute of Internal Auditors, Practice Advisory 2440-2: Communicating Sensitive Information Within and Outside the Chain of Command.

${ }^{107}$ See Pei-Men Tan and Seng-FookOng, Adequacy of Employee Whistleblower Protection in Malaysia, 5 InT’L ProceED. OF ECO. DEV. \& RES. 2; 2011, available online.
} 
managers and internal auditors about their "whistleblowing intention.” This variable combines answers to several survey questions about how strongly respondents feel about the desirability and applicability of whistleblowing to their own work experience. The seriousness of the infraction and the length of the respondents' work experience in the company affect inclinations to complain about improper or illegal behaviour. ${ }^{108}$ Work experience and particularly ethics training predicted positive propensities to blow the whistle on illegal conduct as well. ${ }^{109}$

\section{Figure 26: Ethics Training Seems to Affect the Receptivity of Malaysian Managers and Internal Auditors to Whistleblowing}

\begin{tabular}{|l|l|l|}
\hline Variable Important? & Yes & No \\
\hline Job Function & & \\
\hline Organisation Size & & \\
\hline Gender & & \\
\hline Seriousness of infraction & & \\
\hline Status of wrongdoer & & \\
\hline Age & & \\
\hline Work experience & & \\
\hline Ethics training & & \\
\hline
\end{tabular}

Black shaded boxes indicate a statistically significant correlation at the 5\% level. A "no" shading indicates the lack of such a statistically significant finding.

Sources: Ab-Ghaniet al.(2011), Ahmad et al. (2010).

What specifically are Malaysian managers' propensities and expected results of whistleblowing, should their banks establish internal whistleblowing policies? Figure 27 provides data on attitudes toward whistleblowing specifically in Malaysian banks. ${ }^{110}$ A low integer on the authors' scale indicates an unfavourable attitude or outcome, whereas a higher score represents a favourable or positive outcome. Thus, attitudes measuring a 3.12 (on average) to report wrongdoing (be it anticompetitive behaviour or other malfeasance) to the appropriate bank staff signals rather neutral feelings about whistleblowing. On average, Malaysian bank employees evince unequivocal propensities to report to wrong doing to upper level management. The respondents felt most strongly that "reporting wrongdoing helps prevent serious harm to the bank" (with a score of 4.01 out of 5). However, these staff would be unlikely to "tell a supervisor" scoring only 3.1 on this 5 point scale.

\footnotetext{
${ }^{108}$ See Syahrul Ahmad, Malcolm Smith, and Zubaidah Ismail, Internal Whistleblowing Intentions in Malaysia: Factors that Influence Internal Auditors' Decision-Making Process, ASBES 2011-051155, available online.

${ }^{109}$ Nadzri Ab-Ghani, Jeremy Galbreath and Robert Evans, Predicting Whistle-Blowing Intention Among Supervisors In Malaysia, 3 J. OF GLOBAL MAN. 1, 2011, available online.

${ }^{110}$ See C.H. Ponnu, K. Naidu and W. Zamri, Determinants of Whistle Blowing, 4 INT'L REV. OF Bus. RES. PAP. 1, 2008, available online. The 144 respondents in the survey came from Affin Bank (28\%), Alliance Bank (6\%), Public Bank (10\%), Hong Leong Bank (4\%), Southern Bank (11\%), Maybank (4\%), Am Bank (35\%)and EON Bank (2\%).
} 


\section{Figure 27: Ambivalent Attitudes toward Whistleblowing in Malaysia's Banking Sector}

\begin{tabular}{lrr} 
& \multicolumn{2}{c}{ "bad" } \\
Internal Reporting & 1 & 2 \\
\hline I would report wrongdoing to appropriate person in bank & \\
I would use reporting channels inside bank & \\
I would let upper level management know about it & \\
I would tell supervisor & 2.6 \\
\hline External Reporting & 2.47 \\
I would report it to appropriate authorities outside organisation & 2.11 \\
I would use reporting channels outside bank & 2.1 \\
I would provide info. to outside agencies & \\
I would inform public & \\
\hline
\end{tabular}

Reasons for Whistleblowing

Reporting wrongdoing helps prevent serious harm to bank

Whistleblowing enhances the public interest

4.01

Reporting way to do duty

3.31

Whistleblowing is moral

\section{Results of Whistleblowing}

Bank would hinder/ignore my reporting

Difficulties too great to endure

2.74

Reporting won't make a difference

They will retaliate against me

Source: paraphrased from Ponnu et al.(2008).

We have labelled low scores as "bad" - as they generally reflect attitudes not conducive toward whistleblowing, like disagreeing with the statement in the figure. The "good" scores (toward 5 points) tend to reflect attitudes conducive to whistleblowing - like agreeing with the statements in the figure.

The likely success of whistle blowing measures will depend on economic and other incentives. Specifically, they will depend on the extent to which Malaysian banking sector antitrust compliance programmes are incentive compatible. The economic literature provides some analysis looking at the incentives to adopt and comply with internal antitrust rules. ${ }^{111}$ Well-defined and clear antitrust regulations and controls signal strong interest in complying with legislation like the Competition Act.

Unavailable or poorly defined rules and controls signal that management does not actively seek to follow the law. Petronas provides a positive example - defining clear antitrust rules because of the large losses the company could face in a range of jurisdictions for violating them. Petronas' antitrust guidelines are contained in the company's Code of Conduct and specific guidance is provided in the PETRONAS Competition Guidelines. ${ }^{112}$ As described in Figure 28, the quality of antitrust rules may, in themselves, provide a red flag for internal auditors and regulators examining the probability of company engagement in anticompetitive behaviour. When companies (like Petronas) have large revenues, likely low rents from

\footnotetext{
${ }^{111}$ For an excellent overview, see Rosa Abrantes-Metz and Daniel Sokol, Antitrust Corporate Governance and Compliance, U. OF MINN.. L.S. RES. PAP. 13-18, 2013, available online.

${ }^{112}$ See PETRONAS Code of Conduct and Business Ethics (CoBE), available online. See also PETRONAS Competition Guidelines, available online.
} 
collusion, and large potential losses from a competition authority's investigation, the company will have strong incentives to define good antitrust controls. However, companies operating in protected, domestic markets which generate rents, and which (for political or other reasons) will likely face little competition agency oversight, internal antitrust controls will remain poor, as the incentives to comply simply do not exist.

\section{Figure 28: Poorly Designed Antitrust Controls Can Suggest Anticompetitive Behaviour (Or At Least Indifference)}

Why would a bank establish a whistleblower protection scheme than make it unusable? Why would complaints fail to be investigated internally? Why not ask employees about their perceptions and experiences with collusion and market abuse? Instead of finding anticompetitive behaviour, and then working backwards to see which controls failed, internal auditors can work the other way around. They can look for absent or badly designed policies, and use those to point to areas of potential anticompetitive behaviour. The following shows, in "topic cloud" format, the main red flags which suggest anticompetitive behaviour - or managerial apathy/negligence toward antitrust issues.

1. Antitrust audit. No assessment of antitrust risk during annual audit planning exercise with chief audit officer. No conduct of risk self-assessment to identify risks. No analysis of market data.

2. Hotline. No hotline exists to collect complaints about anticompetitive behaviour. Person taking the calls doesn't have script about what to do in case of complaint.

3. Internal counsel. No procedures for dealing with inquiries by Competition Commission. No training about what to do in case of accusation of anticompetitive behaviour.

4. Whistle-blower protection programme. No whistleblower protection programme in place. No procedures to collect complaints within the organisation.

5. Media monitoring. No monitoring of traditional social media for accusations or hints about anticompetitive behaviour by staff or rivals. Managers never met to discuss how to deal with complaints (no matter how unreliable).

6. Internal investigation. Compliance staff, legal counsel and managers have never questioned anyone on staff about suspected anticompetitive behaviour (or even possible risk/weak points for such behaviour).

7. Feedback on policy. Never gave feedback on policies directly to Commission or through Malaysian Bankers Association.

As we will see in the next section, poor incentives do not just affect whistleblowing; they affect all parts of antitrust compliance. 


\section{The Effect on the Competition Act on Anticompetitive Behaviour in Malaysian Banking}

How much would Malaysian banks, financial services providers and companies pay to avoid investigation by the Competition Commission? Figure 29 shows the amount of antitrust fines paid annually in the US and EU since 2008. ${ }^{113}$ US fines generally hover between $\$ 500$ million and $\$ 1$ billion per year - the amount of money some of the larger Malaysian banks earned in net interest margins over the period. However, EU fines have varied wildly over the period. In 2010, antitrust fines topped $\$ 3.7$ billion, descending the next year by about $\$ 3$ billion. If the Malaysian Competition Commission imposed EU-level fines and punishments, such punishments would strongly encourage Malaysian banks (and other companies) to adopt stringent internal antitrust controls. At US level fines, large Malaysian banks would see a significant or complete evaporation of profits. At EU levels, antitrust fines would impose a de facto death sentence on anticompetitive behaviour (and the organisations engaging in such behaviour). ${ }^{114}$

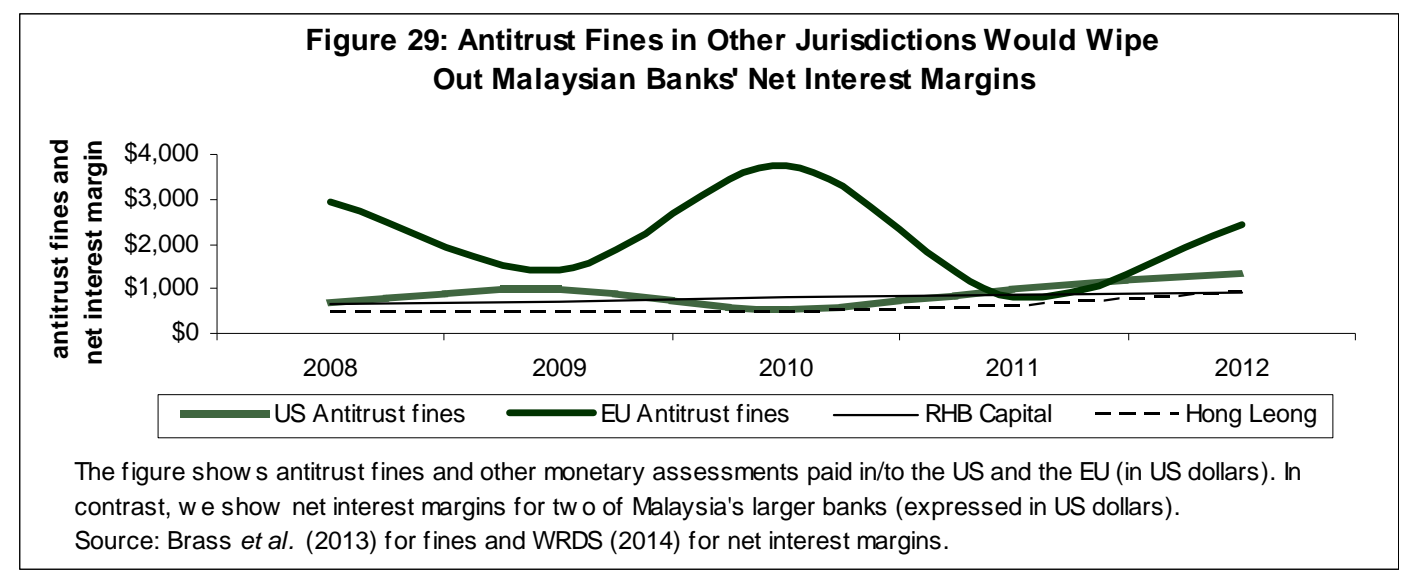

Antitrust investigations and prosecutions can have other effects on a firm's ability to reward anticompetitive behaviour - such as affecting the firm's share price. Shareholders may sell their shares on news of the opening of an antitrust investigation as such investigations are costly in terms of management time, legal fees, and may result in fines so reducing illegal anticompetitive rents which have contributed to the company's profits. As such, even the threat of an antitrust investigation may help deter illegal anticompetitive behaviour - particularly if the cost of such enforcement action exceeds the profits earned from illegal anticompetitive behaviour. Figure 29 shows the effect of announced antitrust

\footnotetext{
${ }^{113}$ See Rachel Brass, David Burns, Nathan, Michael McGinnis, Trey Nicoud, Peter Squeri, Quynh Vu, and David Wood, 2012 Year-End Criminal Antitrust and Competition Law Update, 2013, available online.

${ }^{114}$ Fabra and Motta find that, even with bankruptcy-inducing fines, companies may still have economic incentives to engage in anticompetitive behaviour. Their solution consists of imposing fines based on general economic growth. From the figure in the main text, we see EU competition authorities failed to heed their advice. See Natalia Fabra and Massimo Motta, Antitrust Fines in Times of Crisis, CEPR DP9290, 2013.
} 
enforcement in the EU on target companies' share prices. ${ }^{115}$ If Malaysia follows other countries, an investigation can reduce Malaysian banks' value by up to 5\%. In general, whether well-founded or unfounded, such investigations can reduce a company's valuation over time - on average by about $1 \%$ to $2 \%$. Data from Malaysia shows that such effects hold as much in Malaysia as in the EU. ${ }^{116}$

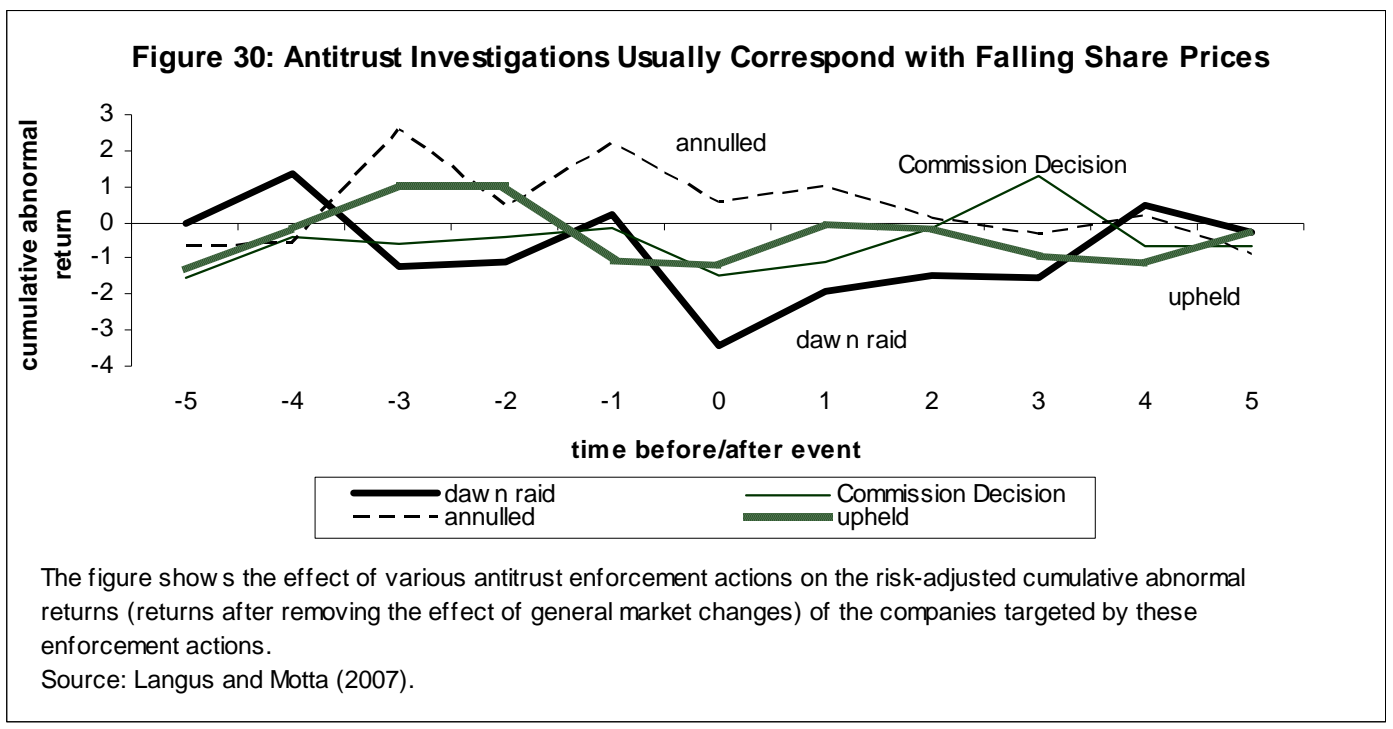

The Competition Act - and accompanying Guidelines on Financial Penalties outlines the approach of the Competition Commission to the imposition of penalties and remedies anticompetitive behaviour. Figure 31 provides a summary review of these remedies - and their likely effect on banks. The Competition Commission has five tools at its disposal. The Commission can require banks to stop their anticompetitive activity. ${ }^{117}$ Such orders leave previous gains intact, and such a 'remedy' may simply encourage banks to better conceal their unlawful activity in the future. Similarly, the Commission may require banks to undertake particular actions (or avoid others) in order to eliminate their anticompetitive behaviour. ${ }^{118}$ The Commission may impose fines, maxing out at 10 million ringgit, for activities which help anticompetitive behaviour illegally try to avoid detection or

\footnotetext{
${ }^{115}$ See Gregor Langus, Massimo Motta, and Luca Aguzzoni. The Impact of EU antitrust investigations and fines on a firm's valuation. CEPR DP 6176, available online.

${ }^{116}$ We do not have good data allowing us to analyse the way antitrust investigations in Malaysia affect Malaysian company share prices. However, studies exist about the way that investigations for other types of economic crimes affect Malaysian equity prices. For an example (showing that criminal investigations lead to declining share prices in the Malaysian context), see Chin-Hong Puah and Wei-Siew Liew, White-collar crime and stock return: Empirical study from announcement effect, MPRA Paper 31748, 2011, available online.

${ }^{117}$ The Commission can "require that the infringement to be ceased immediately...[and] may specify steps which are required to be taken by the infringing enterprise, which appear to the Commission to be appropriate for bringing the infringement to an end." Competition Act at 40.1(a)-(b). We have removed lettered list format in the original for ease of reading.

${ }^{118}$ The Commission "may give any other direction as it deems appropriate.” In this context, such "direction" probably includes requirements to end contracts, instructions about setting prices (fees), requirements to provide financial services to particular organisations, and so forth. Id. at 40.1(d).
} 
prosecution. ${ }^{119}$ We show later in this section such fines will probably fail to deter anticompetitive behaviour. The Commission may put bankers in prison. ${ }^{120}$ In theory, the Act may allow the Commission to impose US-style monitorships and require the company to engage in costly compliance activity which basically services a punitive purpose. ${ }^{121}$ Most importantly, the Commission may impose penalties of up to $10 \%$ of the company's world-wide revenue "[during] the period [in] which an [antitrust] infringement occurred.”"122

\section{Figure 31: Potential Remedies for Anticompetitive Behaviour By Malaysia's Financial Service Providers}

\begin{tabular}{|c|c|c|}
\hline Remedy & Likely effect on banks & Citation \\
\hline $\begin{array}{l}\text { Cease and desist } \\
\text { orders }\end{array}$ & $\begin{array}{l}\text { Keeps their anticompetitive rents intact - so unlikely to } \\
\text { have any effect. }\end{array}$ & $40(1)(a)$ \\
\hline $\begin{array}{l}\text { Positive or negative } \\
\text { injunctions to } \\
\text { restrain or require } \\
\text { future conduct }\end{array}$ & $\begin{array}{l}\text { Likely to encourage banks to hide anticompetitive } \\
\text { behaviour better rather than discourage such behaviour. }\end{array}$ & $40(1)(b)$ \\
\hline $\begin{array}{l}\text { Fines for obstruction } \\
\text { of justice-type } \\
\text { "offences" }\end{array}$ & $\begin{array}{l}\text { Can demotivate and remove previous profits from } \\
\text { anticompetitive behaviour up to RM10 million, with } \\
\text { likely result of increasing anticompetitive behaviour. } \\
\text { These consist of penalties for "offences" which we } \\
\text { describe in the main text. }\end{array}$ & $\begin{array}{l}\text { 61(a)-(b) and } \\
65(3)\end{array}$ \\
\hline Imprisonment & $\begin{array}{l}\text { No imprisonment for substantive anti-competitive acts, } \\
\text { only for obstruction of investigations or destruction of } \\
\text { evidence or Little (as most jurisdictions do not use jail } \\
\text { as a serious deterrent or punishment). }\end{array}$ & $\begin{array}{l}23,24,25,32,33 \\
34 \& 61,62\end{array}$ \\
\hline $\begin{array}{l}\text { "Penalties" of up to } \\
10 \% \text { of world-wide } \\
\text { turnover for the } \\
\text { period of the } \\
\text { infringement }\end{array}$ & $\begin{array}{l}\text { Slightly reduces profits. These consist of the } \\
\text { "infractions" of the Act which we describe in the main } \\
\text { text. }\end{array}$ & $40.1(4)$ \\
\hline \multicolumn{3}{|c|}{$\begin{array}{l}\text { Source: Competition Act (2012), with interpretation by authors. We do not analyse the effects of } \\
\text { Commission orders (like injunctive or mandamus orders) to focus on the effects of financial } \\
\text { penalties. }\end{array}$} \\
\hline \multicolumn{3}{|c|}{$\begin{array}{l}119 \text { We describe these fines in more detail later in this section. The Act allows for fines applied to } \\
\text { individuals as well as companies. We focus on fines to the company and not the relatively } \\
\text { inconsequential fines of } 2 \text { million ringgit (or about } \$ 617,000 \text { ) for individuals convicted under the } \\
\text { Act. } \\
120 \text { The Act allows for (besides fines), "imprisonment for a term not exceeding five years." Id at } \\
61 \text { (b). } \\
\text { 121 To many, the wide ranging regulations imposed on banks after } 2008 \text { represent an attempt to } \\
\text { punish as much as regulate. Less controversially, a competition authority may engage in agreements } \\
\text { which require extensive monitoring or even temporary custodianship of the corporate perpetrator. In } \\
\text { the US, authorities have recently used non-prosecution agreements and monitorships to enforce } \\
\text { antitrust law. Such agreements require that offending companies engage an independent monitor to } \\
\text { oversee company activity. See Joel Levin, A Rare Sight: DOJ Antitrust Division Uses Non- } \\
\text { Prosecution Agreement To Resolve Bid Rigging Allegations Against UBS, PERKINS CoIE BRIEF, } \\
2011 \text {, available online. }\end{array}$} \\
\hline
\end{tabular}


Internal auditors need to look at (and keep clear in their minds) both risks of "infringement" and the commission of "offences." An 'infringement' under the Act consists of the abuse of market power or collusion. An 'offence' however, consists of activities aimed at concealing the infringement or other "obstruction of justice" type activities we describe in the paper. Importantly, 'offences' are punished through criminal penalties, whereas 'infringements' are punished through civil (revenue-based) penalties.

Fines for 'obstruction of justice' style offences will not discourage "supporting behaviours" to anticompetitive behaviour (to the extent it occurs) in Malaysia's banking sector. ${ }^{123}$ At present, 10 million ringgit seems the maximum penalty Malaysian banks might face for offences committed under the Competition Act. ${ }^{124}$ Separately, the Financial Services Act provides that "any person who [engages in anticompetitive behaviour] commits an offence and shall, on conviction, be liable to imprisonment for a term not exceeding five years or to a fine not exceeding ten million ringgit or to both." 125 As for the Competition Act (and we still talk here about “offences", not "infringements" punishable by revenue penalties), the Act sets fines of 5 million ringgits for companies for their first offence, and 10 million for their second offence. ${ }^{126}$ For individuals (natural persons), the Act provides for a fine of 1 million ringgit for the first offence and 2 million for the second and subsequent offences (in addition to jail time). ${ }^{127}$ If the Competition Commission sets penalties for other offence-type behaviour, they can impose "a fine not exceeding one million ringgit, or imprisonment for a term not exceeding five years or to both.”128

Such maximum fines provide exceedingly scant deterrence to Malaysia's banks seeking to conceal anticompetitive behaviour. Figure 32 shows income earned by Malaysia's banks in 2012, and compares such income with the maximum fines allowable under the Financial Services or Competition Acts for committing "offences” (again, this does not account for "infringements” that are penalised

\footnotetext{
${ }^{123}$ We address "supporting behaviours" to anticompetitive behaviour because the Competition Act makes a distinction between financial penalties for "infringements" (which are the actual anticompetitive behaviour itself) and "offences" (which are behaviours that generally illegally hinder the Competition Commission. Some of these offences include failure to produce records at the Commission's request (art. 20), disclosure or use of confidential information (art. 21), giving false or misleading information (art. 23), destroying or mutilating records (art. 24), breaking a seal on evidence (art. 25.7), obstructs Commission access to premises (art. 32), tips of perpetrators (art. 33), threaten or actually seek revenge for whistleblowing (art. 34), or acts which future regulations define as an offence (art. 65.3).

${ }^{124}$ We discuss revenue-based penalties for 'infringements' later in this section. We discuss fines, as they feature prominently in recent Malaysian antitrust cases - particularly the Malaysian Airlines/Air Asia case. See Star, MAS-AirAsia infringed Competition Act, fined RM10mil each, Star Online, available online.

${ }^{125}$ Financial Services Act at 124(4).

${ }^{126}$ Competition Act at art. 61(a)

${ }^{127}$ Competition Act at art. 61(b).
} 
according to $10 \%$ of worldwide revenue). For Malaysia's largest earning banks, the 10 million ringgit maximum fine for an offence under either act represents a miniscule proportion of their annual income. For Malaysia's lowest-earning banks, the fine represents less than half of a year's income. ${ }^{129}$ We only talk now about fines for offences-- not the infractions which constitute anticompetitive behaviour.

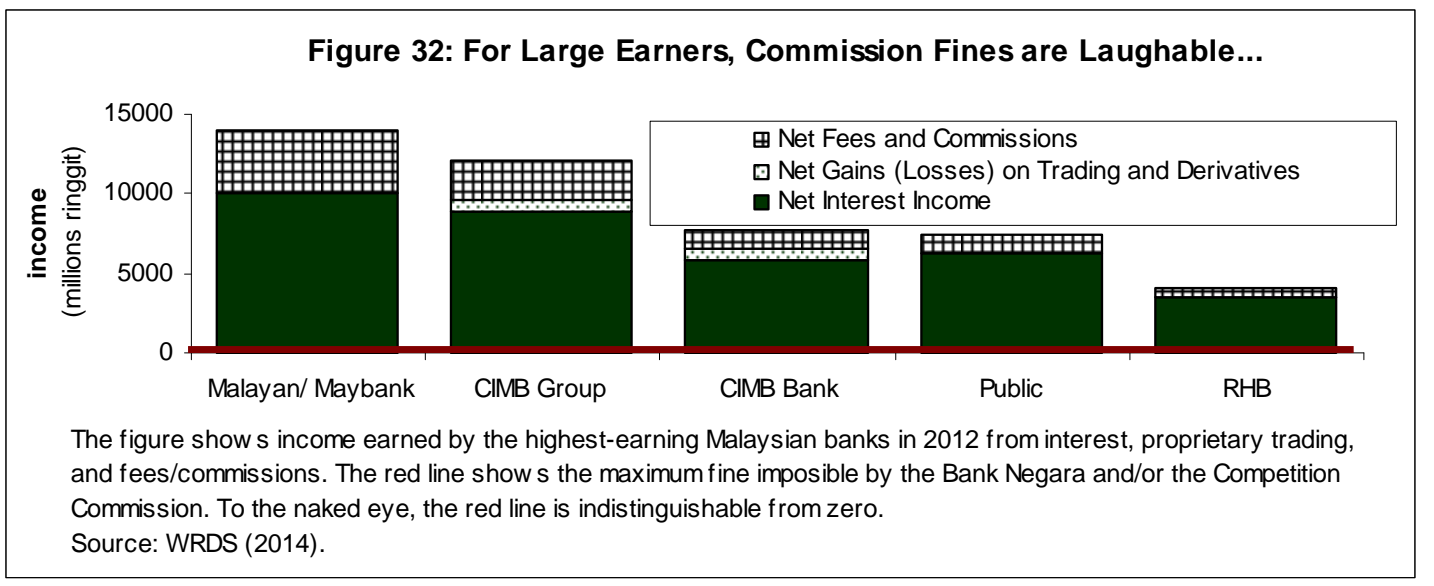

Figure 32 (continued) ... and Even for Lowest Earners, Commission Fines Are Minor

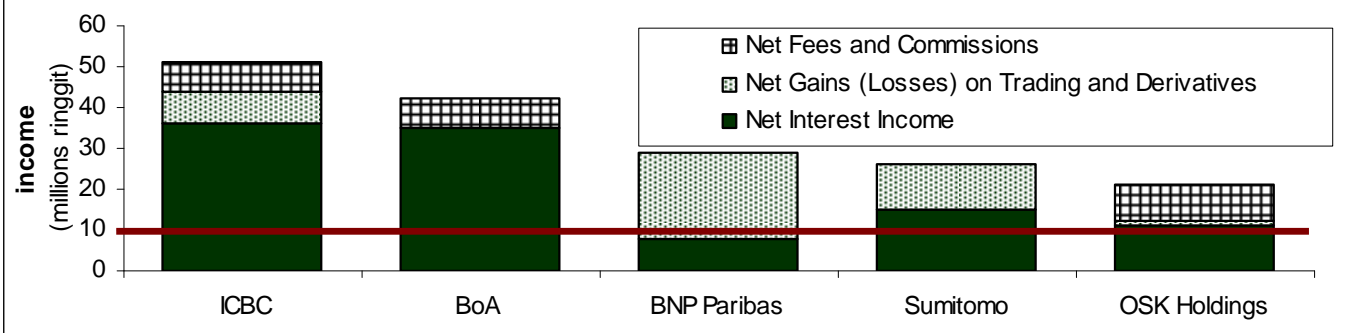

The figure show s income earned by the low est-earning Malaysian banks in 2012 from interest, proprietary trading, and fees/commissions. The red line show s the maximum fine imposible by the Bank Negara and/or the Competition Commission. Even the low est earning banks have no problem paying such a fine.

Source: WRDS (2014).

Worse still, fixed maximum fines may actually encourage banks to attempt to hide their anticompetitive behaviour. ${ }^{130}$ Figure 33 shows why the imposition of a low, maximum fine (relative to income and thus likely collusive rents) encourages all groups of Malaysian banks to increase illegal efforts to avoiding the detection of their anticompetitive behaviour. The figure describes the logic main for applying fines for "offences" -- not for revenue-based "infractions." In relation to the group of banks which do not engage in anticompetitive behaviour, they earn no rents (and

\footnotetext{
${ }^{129}$ Markham makes the other valid point that such fines punish banks' shareholders and investors rather than the managers actually engaging in anticompetitive behaviour, further reducing the disincentives to prevent anticompetitive activity. See Jesse Markham, The Failure of Corporate Governance Standards and Antitrust Compliance, 58 S. DAK. L. REV. 3, 2013.

${ }^{130}$ Many other academics have discovered this fact before. Jensen et al. specifically quantify the exact conditions under which fines like the Competition Commission's will lead banks to conceal their anticompetitive behaviour rather than reduce it. See Sissel Jensen, Ola Kvaloy, Trond Olsen and Lars Sorgard, Crime and punishment: When tougher antitrust enforcement leads to higher overcharge, NORWEGIAN SCH. OF ECON. WP 4, 2013, available online.
} 
we label the amount of rents earned by this group as $A$ ). Because they now must pay compliance costs, they have incentives to increase their anticompetitive behaviour (given the likely low probability of detection) to cover these new costs. ${ }^{131}$ The new level of rents they earn rises to $A$ '. At the best, they just ignore the Competition Act (such that $A=A^{\prime}$ ). Groups of banks that flagrantly collude and abuse their market power (earning more than RM10 million in rents) should just continue. In the figure, we show this group as earning $D$ in rents. We assume that their rents after the highly imperfect enforcement of the Competition Act remain at $D^{\prime}$ ' (such that $\left.D=D^{\prime}\right)$. Even if the Competition Commission catches these banks, after paying the fine, they still profit from anticompetitive behaviour. ${ }^{132}$

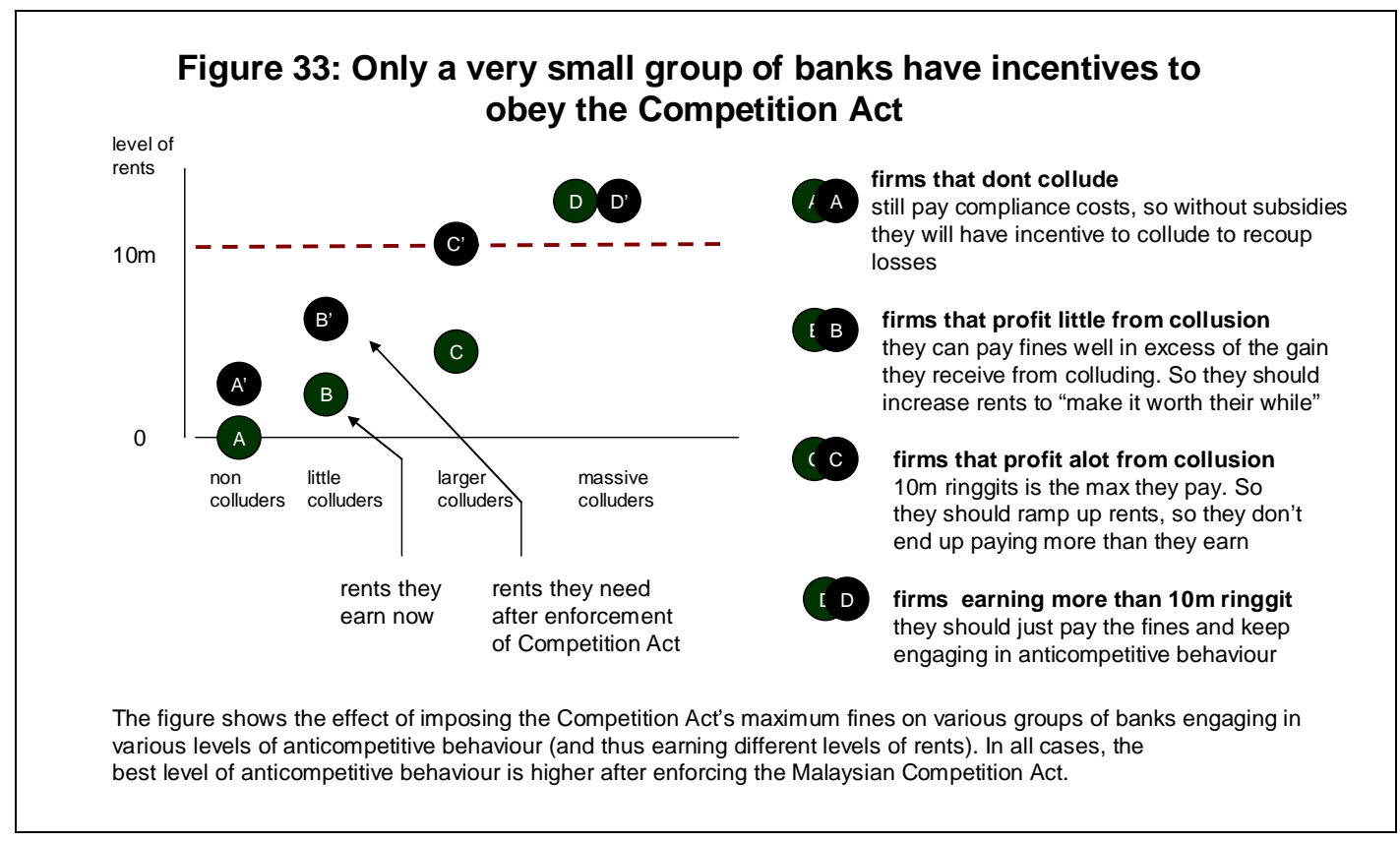

The interesting cases concern Malaysian banks which earn less than RM10 million. Banks earning far less - like RM2 million in rents - should bump up anticompetitive behaviour just a bit. ${ }^{133}$ They know that Competition Commission fines for trying to conceal anticompetitive behaviour they have already engaged in will likely equal or exceed their present rents. In that case, they should increase

\footnotetext{
${ }^{131}$ Other academics have found such an effect ("clean" companies purposely engaging in anticompetitive behaviour because of antitrust fines). See Maarten Schinkel and Jan Tuinstra, Imperfect competition law enforcement, 24 INT'L J. OF INDUST. ORG. 6, 2006,

${ }^{132}$ Not everyone would likely agree that fines would motivate companies to engage in more anticompetitive behaviour. Huschelrath and co-authors ask a bunch of Swiss lawyers if they (the lawyers) thought increased penalties under the revised Swiss antitrust law deterred companies. Unsurprisingly (and rather self-servingly), these lawyers thought that steeper penalties deterred Swiss companies from anticompetitive behaviour. Interestingly, deterrence comes from dawn raids and other repressive measures, rather than any attempt to put a flat maximum fine in place à la Malaysia. See Kai Huschelrath, Nina Leheyda and Patrick Beschorner, The Deterrent Effect of Antitrust Sanctions: Evidence from Switzerland, 56 ANTITRUST BULL. 427, 2011.

${ }^{133}$ If the Competition Commission can infinitely compound fines (as we have previous described). they can choose exactly the right level of fines to eliminate the incentives we describe in this section.
} 
anticompetitive behaviour (and thus rents) in order to make their current rentearning "worth while." For banks that earn a bit more - let's say RM7 million for example - they should actively seek out to engage in rent-earning anticompetitive behaviour. ${ }^{134}$ The relevant authorities will probably have little mercy on them. So they should at least earn the damages they will pay. ${ }^{135}$ In either case, banks should "invest" in hiding their anticompetitive behaviour from the Competition Commission.

What about prison time? In theory, prison time should serve as a deterrent to Malaysian bankers engaging in illegal anticompetitive behaviour and then trying to hide such behaviour. However, three factors militate against prison times in the Act as an effective deterrent. First, the Bank Negara and the police more generally have prosecuted relatively little white collar crime - and thrown even fewer in prison. ${ }^{136}$ The Bank Negara reports relatively few cases on its website, and statistics on the prosecution of corporate and white-collar crime in Malaysia suggest that antitrust enforcement would take a back seat to other types of law enforcement - like fraud. ${ }^{137}$ Second, high-level bank managers will unlikely attract vicarious liability for collusion, market abuse or obstruction of justice of their sub-ordinates (agents). ${ }^{138}$ As such, prison time does not provide a sufficient enough reason for senior managers to put stronger controls in place. Third, even taking the expected financial and psychological costs of imprisonment into account, the benefits of anticompetitive behaviour and hiding such behaviour still probably exceed the costs. The total costs of imprisonment may amount to US\$250,000 in foregone salary and "disutility" of poor treatment in jail. However, even a probable detection $10 \%$

\footnotetext{
${ }^{134}$ The level at which fines start to encourage banks (and other companies) to conceal their anticompetitive behaviour will depend on the benefits from collusion, ease of collusion, costs of production, costs of concealment and other factors. As we do not have these data for Malaysian financial institutions, we can not repeat this analysis. See Maria Avramovich, Prosecuting Cartels: Do High Fines Always Contribute to Social Welfare? available online.

${ }^{135}$ Economists argue about whether fines should aim to remove the banks' revenue from anticompetitive behaviour or additionally seek to undue the reduction in consumer welfare. Interestingly, in either case, the best policy (for the competition authority) consists of allowing a certain low level of anticompetitive behaviour. See Said Souam, Optimal antitrust policy under different regimes of fines, 19 INT'L J. OF INDUST. ORG. 1-2, 2001. Interestingly, even a fine based on revenue may still be too low. For an analysis redolent of ours, see Iwan Bos and Maarten Pieter Schinkel, On The Scope For The European Commission's 2006 Fining Guidelines Under the Legal Maximum Fine, 2 J. OF COMP. L. \& ECON 4, 2006.

${ }^{136} \mathrm{Few}$ jurisdictions send large numbers of antitrust violators to jail. Even in the US, median jail times have not exceeded one year. For data on the US's enforcement practices, see Beryl Howell, Sentencing Of Antitrust Offenders: What Does The Data Show? US SENTENCING COMMISSION INTERNAL PAPER, available online.

${ }^{137}$ The Bank Negara reports around 45 cases under investigation at the time of this writing (though the Bank does not provide information about the date on which its cases list is updated). See Bank Negara, Status of Cases Investigated, available online. Crime statistics in Malaysia are notoriously difficult to come by. For an analysis of white collar crime in Malaysia, see Wei-Siew Liew, ChinHong Puah, and Harry Entebang, White-collar crime: a statistical study on its common causes, 2 INT’L J. OF BUS., MAN., AND SOC. SCI. 4, 2011.

${ }^{138}$ For a survey, see Chee-Wee Lim, Criminal Liability of Companies Survey: Malaysia, 2008, available online.
} 
lowers that amount to an expected US\$25,000. ${ }^{139}$ Rational Malaysian bank managers will engage in illegal anticompetitive behaviour if such anticompetitive behaviour raises that bank manager's value of his or her stock options, commissions, and the value of improved chances at a higher paying promotion more than $\$ 25,000$. Putting criminal bank managers in prison won't encourage compliance with the Competition Act as long as the expected benefits of anticompetitive behaviour exceed the expected costs.

The most interesting case concerns the revenue-based penalties in the Act. The Malaysian Competition Act imposes a maximum limit of $10 \%$ of a company's worldwide revenue for financial penalties - applicable on revenues earned over the period of the anticompetitive conduct. As Figures 34 show, such limits would be unlikely to dissuade Malaysia's banks. In the case of anticompetitive conduct lasting only one year, the first panel shows the profits of the most profitable Malaysian banks, after paying a hypothetical 10\% revenue fine. The largest banks continue to earn profits of over 1 billion ringgit even after deducting $10 \%$ of the value of these banks' revenues. As shown by the black boxes above each bar in the figure, thepenalties amount to approximately 30\% of 2012 profits.

For medium-profit range banks, such fines shrink profits much more dramatically albeit with a greater range of outcomes. AmIslamic’s 2012 profits shrink by $60 \%$ when its revenues fall by $10 \%$. Malaysian Industrial Development Finance Bank's profits, on the other hand, fall by only 18\%. Maximum fines hurt these banks - but the gains from anticompetitive behaviour may still tempt them more than the possibility of penalties imposed by the Competition Commission would dissuade them from unlawful but profitable anticompetitive activity.

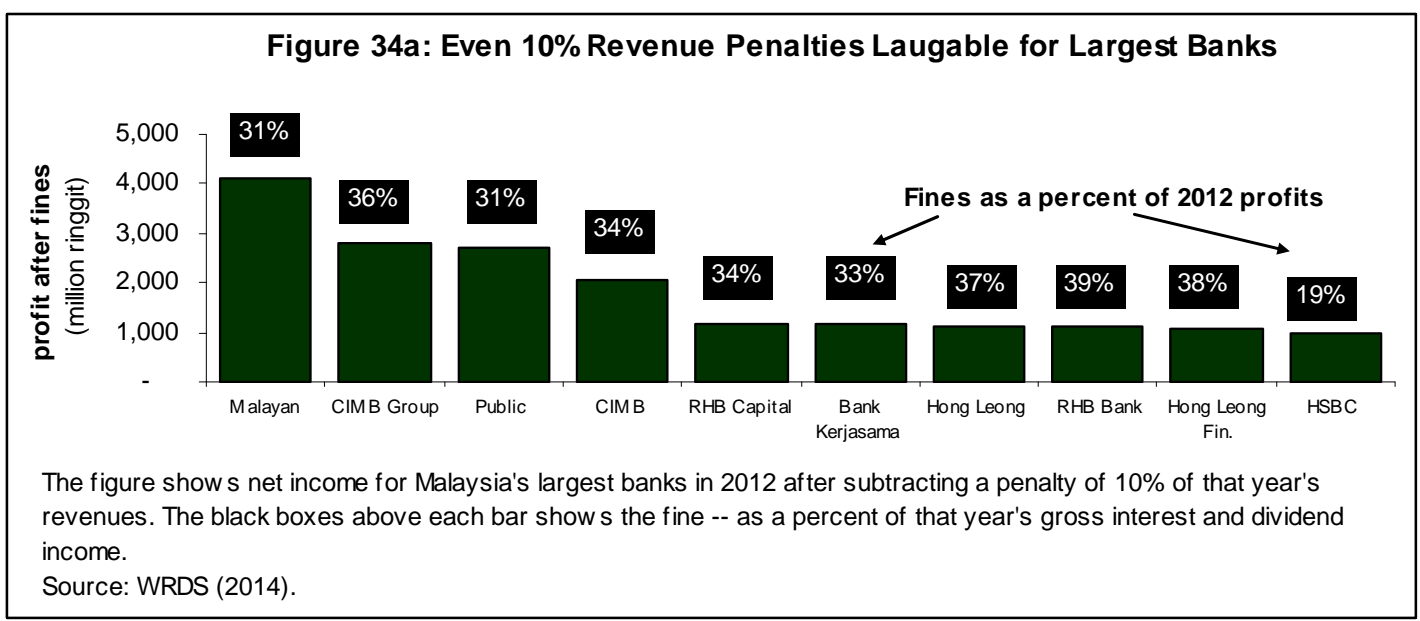

\footnotetext{
${ }^{139}$ As we previously discussed, "expected” outcomes relate to the value of a cost or benefit multiplied by the probability of that outcome. To take a simple example, a pay-off worth $\$ 100$ with a probability of $50 \%$ of occurring would have an expected value of $\$ 50$.
} 

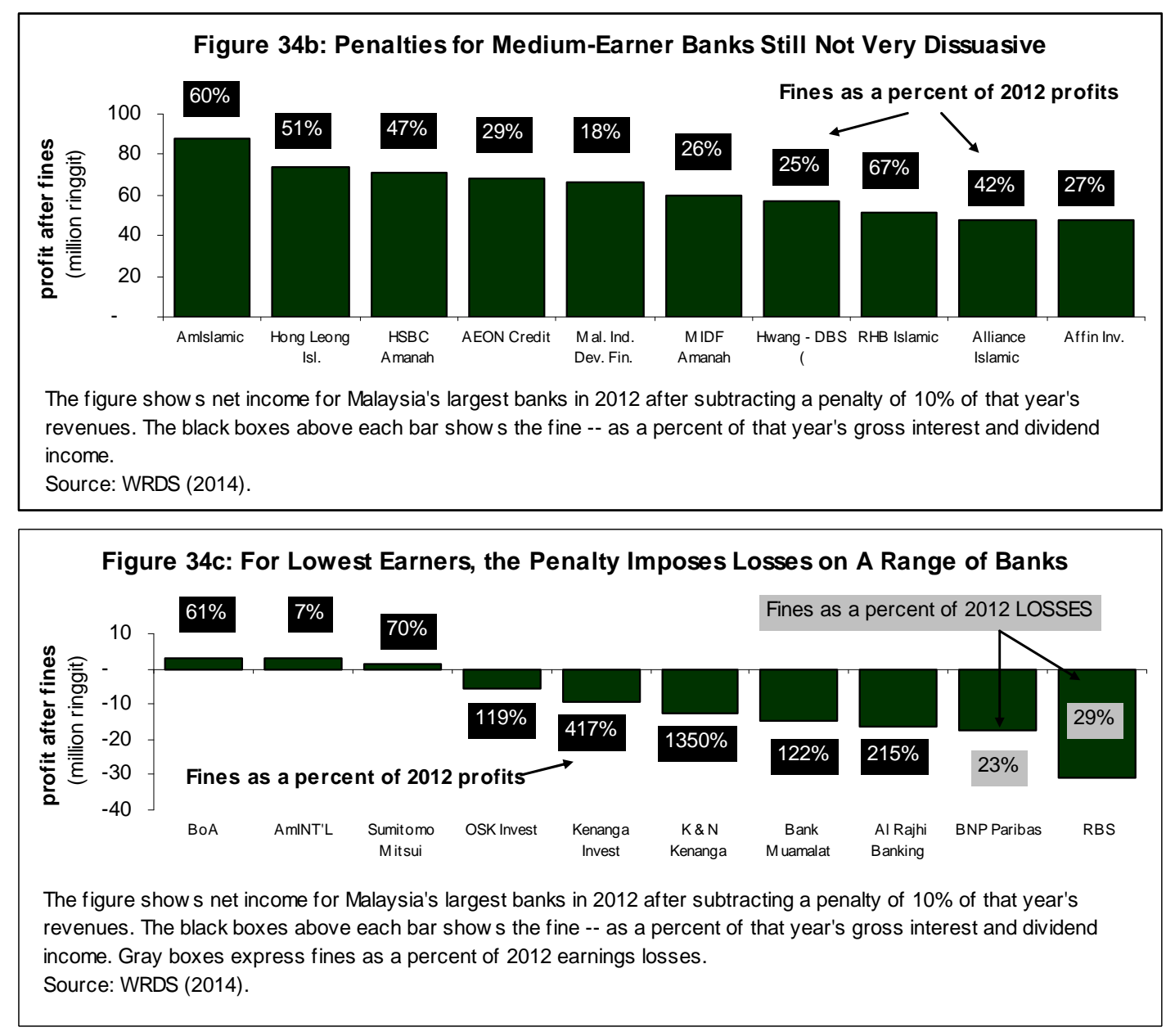

The lowest earning Malaysian banks represent the most interesting case for analysis - and the bank group most likely to be affected by the Competition Commission's revenue-tied penalties. The Bank of America’s profits in Malaysia would fall by 61\% in 2012 if the Competition Commission had imposed a 10\% revenue fine. AmInternational's profits would not decrease - because its revenue had been so low. Competition Commission fines would only significantly adversely affect OSK Investment, Kenanga Investment, K \& N Kenanga Holdings, Bank Muamalat and Al-Rajhiby forcing them into an actual loss. ${ }^{140}$ If the banks listed in Figure 34c also received maximum fines of RM10 million, they would all report net losses (negative earnings) in 2012, though none would become insolvent. ${ }^{141}$

\footnotetext{
${ }^{140}$ BNP Paribas and Royal Bank of Scotland already lost money in 2012. As such, Competition Commission fines would deepen their losses.

${ }^{141}$ Academics have recently wondered whether various antitrust fine structures would encourage bankruptcies - and what effect the threat of bankruptcies might have on anticompetitive behaviour. Such ruminations particularly concern the banking sector - as any fine structure which causes bankruptcies could undermine general banking sector stability. Fortunately, as such a possibility seems highly unlikely in Malaysia, we discuss this issue no further. See Andreas Stephan, The Bankruptcy Wildcard in Cartel Cases, CENTRE FOR COMP. POL. WP 06-5, available online.
} 
How much money will anticompetitive behaviour likely earn Malaysian banks? Figure 35 provides a back-of-the-envelope calculation of such benefits. Net interest revenue equalled RM74.3 billion in 2012 and RM19 billion from fees and commissions. Thus, total revenue equalledRM93 billion in 2012. We know that prices are $25 \%$ higher than need to be (according to market power estimates from Figure 3). If these higher prices come from anticompetitive behaviour, rents in Malaysia's banking sector come to around RM18.6 billion, under the very liberal assumptions we make. We also know that, from data from the EU and US, that detection rates hover at about $10 \%$-- with rates of 33\% representing extremely good outcomes. ${ }^{142}$ Detection at a very optimistic $10 \%$ still means that the expected benefit equals about 16.7 billion. ${ }^{143}$ The rationality (from an economic point of view) in hiding such anticompetitive behaviour results from the fact that even if all 75 Malaysian banks paid the maximum fines for concealing their anticompetitive behaviour (thus constituting an “offence”, punishable by a maximum criminal penalty of RM10 million), ${ }^{144}$ and for actually engaging in the anticompetitive behaviour (thus constituting an "infringement"/infraction, punishable by a maximum civil penalty of $10 \%$ of worldwide revenue) equals a total fine payable of RM1.68 billion(where RM750 million results from fines for committing the 'offence' of concealment and RM930 results from the 10\% payable upon the revenue of RM93 billion for “infringements”/“infractions”). Even after Competition Commission enforcement, Malaysian banks can still expect (under our simplifying assumptions) to earn about RM15 billion in rents. Of course these are simply illustrative numbers. However, they show that even with much less market power, Malaysian banks would likely have strong incentives not to comply with the Competition Act. ${ }^{145}$

\footnotetext{
${ }^{142}$ In the EU, such detection rates hover at about $10 \%$, with significant variance in estimated detection rates. The Malaysian Competition Commission (as we previously showed) does not have and will not have for about 20 years - the same effectiveness as its EU counterparts. We give the Commission the benefit of the doubt, but assuming a relatively high $10 \%$ probability of detection in Malaysia. See Emmanuel Combe, Constance Monnier, and Renaud Legal, Cartels: the Probability of Getting Caught in the European Union, BEER PAPER 12, 2008, available online.

${ }^{143}$ Renda and colleagues provide quantification of detection rates in Table 2 . They tend to exceed those estimated by Combe and colleagues. See Andrea Renda, John Peysner, Alan Riley, Barry Rodger, Roger Van Den Bergh, Sonja Keske, Luiss Carli, Roberto Pardolesi, Enrico Camilli and Paolo Caprile, Making antitrust damages actions more effective in the EU: welfare impact and potential scenarios, DG COMP/2006/A3/012, available online.

${ }^{144}$ Competition Act at art 61(a).

${ }^{145}$ We do not have space to describe why the Competition Act's revenue penalties and fines are set too low to serve as an effective deterrent to anticompetitive behaviour in Malaysia's banking sector. Part of the problem stems from the nature of tying fines to revenue (rather than lost consumer surplus). Part of the problem stems from the unique economics of Malaysia's banking sector. For more on the first problem, see Natalia Fabra and Massimo Motta, Antitrust Fines in Times of Crisis, CEPR DISC. PAP. 9290, available online.
} 
Figure 35: How Much Rents Can Malaysia's Bank Expect to Earn?

RM93 billion

$25 \%$

RM 18.6billion

$10 \%$

RM 16.7billion

RM 750 million

RM 930 million

RM 15 billion total revenue from our bank sample in $2012^{*}$

likely mark-ups from market power (from figure 3)

likely rents earned by Malaysian banks

likely detection rate*ᄎ

expected gain before chance to getting caught

maximum fine even if all 75 banks paid max fine

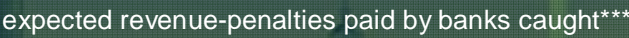

expected gain from anticompetitive behaviour at 2012 income

In the figure, we make the pessimistic assumption that banks both engage in anticompetitive behaviour as well as try to hide such behaviour -

thus commiting both "infringements" and "offences" (using the language of the Competition Act).

* Net interest revenue equalled 74.3 billion riggit in 2012 and 19 billion from fees and commissions.

** the EU and US have detection rates maxing out at $33 \%$. With this detection rate, $90 \%$ of banks go unhindered - thus earning almost RM17

billion in rents.

*** Ten percent of these banks total revenue equals RM9.3 billion. With a $10 \%$ probability of being caught, the expected value of these fines

comes to 930 million.

\section{The Cost of Antitrust Internal Audit in the Malaysian Financial Service Sector}

The amount of money banks and other firms will spend on antitrust compliance depends on the cost of non-compliance. In other words, banks rationally should spend no more money on antitrust controls than they could lose from antitrust investigations and prosecutions. ${ }^{146}$ If the benefits from collusion and market abuse exceed the costs from prosecution, companies should rationally engage in anticompetitive behaviour. ${ }^{147}$ Leaving aside the issue of jail time, if the benefits of anticompetitive behaviour exceed the costs (in terms of compliance and criminal, civil and administrative fines and private action awards), banks will engage in anticompetitive behaviour.

At first glance, Malaysian banks seem to have little to lose from setting up antitrust internal audit programmes and procedures. The cost of antitrust compliance programmes will likely exceed US $\$ 100,000$ or RM330,000 in the first years. Figure 36 shows a breakdown of these costs. For roughly 70 banks, these costs - if banks actually paid them - would amount to RM21.1 million for the banking sector. At first glance, an expenditure of RM330,000 per bank to save millions in fines and penalties seems like a bargain.

\footnotetext{
${ }^{146}$ Despite over 50 academics writing about individuals' incentives to follow criminal and civil laws, we are still surprised by many policymakers' refusal to consider the economic aspects of antitrust compliance and enforcement. For an early example of such an academic, see Alan Beckenstein and Landis Gabel, The Economics of Antitrust Compliance, 52 SouTHERn Econ. J. 3, 1986. For a more recent treatment in firms' incentives to follow Europe's antitrust law, see Wouter Wils, THE OPTIMAL ENFORCEMENT OF EC ANTITRUST LAW: ESSAYS IN LAW \& ECONOMICS, 2002.

${ }^{147}$ For example, Huschelrath finds that US and Dutch antitrust policy works because the benefits of antitrust enforcement exceed the costs. Companies in these two jurisdictions face penalties from national antitrust enforcement agencies larger than the gains from anticompetitive behaviour. See Kai Huschelrath, Is it Worth all the Trouble? The Costs and Benefits of Antitrust Enforcement, CENTER FOR EURO. ECON. RES. Dis. PAP. 08-107, 2008, available online.
} 
Figure 36: Compliance Programmes Likely to Top \$100,000 in First Years

\begin{tabular}{|c|c|c|c|}
\hline Element & $\begin{array}{l}\text { Number man } \\
\text { days }\end{array}$ & $\begin{array}{l}\text { Cost per day } \\
\text { (in ringgit) }\end{array}$ & Total cost \\
\hline $\begin{array}{l}\text { Employee training } \\
\text { (including material development) }\end{array}$ & 10 & 660 & 660 \\
\hline Participative "risk register" & 2 & 2,475 & 4,950 \\
\hline Whistleblowing & 15 & 1,155 & 17,325 \\
\hline Consultations with counsel & 5 & 1,650 & 8,250 \\
\hline Internal investigations & 25 & 1,980 & 49,500 \\
\hline Risk-based project audits & 15 & 1,980 & 29,700 \\
\hline Data monitoring & 20 & 2,475 & 49,500 \\
\hline Competitive anti-trust intelligence & 30 & 2,475 & 74,250 \\
\hline Industry group monitoring & 3 & 1,650 & 4,950 \\
\hline Due diligence on borrowers & 40 & 2,640 & 105,600 \\
\hline & 165 & 2,125 & RM250,625 \\
\hline \multicolumn{4}{|c|}{$\begin{array}{l}\text { * Represents the weighted average by number of man-days. } \\
\text { Originally worked out in USD and converted to ringgit at RM3.3 to } \$ 1 \text {. } \\
\text { Source: based on ICC (2013). }\end{array}$} \\
\hline \multicolumn{4}{|c|}{$\begin{array}{l}\text { For most banks, such spending does represent a bargain. Yet, for a group of banks } \\
\text { (or any bank in the wrong year) even these relatively minor compliance costs would } \\
\text { lead to significant declines in profits and increases in operating costs. Figure } 37 \\
\text { shows the extent to which the antitrust compliance costs described above would } \\
\text { impact on Malaysian banks' profits and administrative spending in years in which } \\
\text { these profits and expenses are particularly vulnerable. For example, in } 2011 \text {, the } \\
\text { antitrust compliance programme we described above would result in almost } 100 \% \\
\text { of Asian Finance Bank's net income (profits). Such a compliance programme } \\
\text { would represent about } 8 \% \text { of Hong Leong's non-interest spending for } 2010 \text {. On the } \\
\text { one hand, Malaysian bank's profits can generally withstand Competition } \\
\text { Commission fines. }{ }^{148} \text { On the other hand, depending on the year, their profits } \\
\text { may not even be enough to pay for an adequate antitrust compliance } \\
\text { programme. }\end{array}$} \\
\hline
\end{tabular}

\footnotetext{
${ }^{148}$ We remind the reader these fines come about as the result of efforts aimed at concealing anticompetitive behaviour or otherwise trying to frustrate the Commission's activities.). With compounding fines, banks and financial firms will find hiding anticompetitive behaviour far less profitable.
} 
Figure 37: For some banks in some years, even a small increase in compliance costs could mean significantly reduced profits

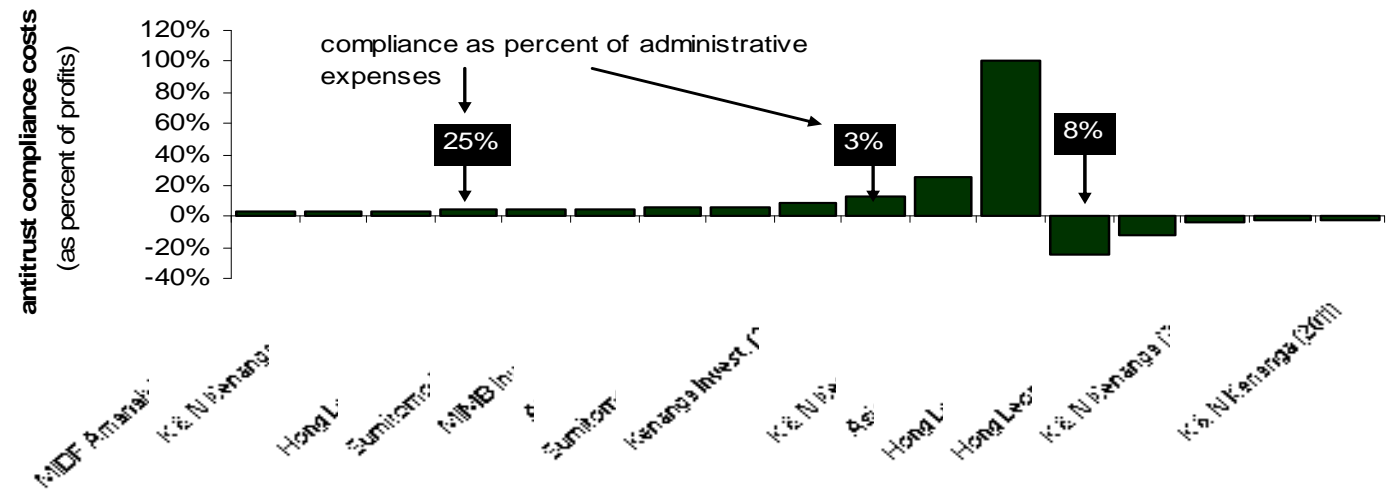

The figure show s the extent to w hich the "standard" antitrust compliance programme we defined in the paper (costing about RM250,000 in the first year) w ould impact on profits and administrative expenses in selected years. We chose the years in w hich this expense is less than $10 \%$ or $-10 \%$ to keep the chart readable. We use net income for profits and total non-interest expenses.

Source: WRDS (2014) and authors.

Yet, the evidence suggests that banks should spend far less than the amount needed to prevent, detect and stop anticompetitive behaviour. Prof. Stephan, using historical case studies from the US, argues that the compliance programmes that many companies (like banks) use today would not have prevented prosecution in the past. ${ }^{149}$ Given the limited range of employees tempted by the incentives to engage in anticompetitive behaviour, a targeted compliance programme may help manage compliance-related costs better than a general company-wide programme. Figure 38 shows the frequency by which various types of employees have been prosecuted for anticompetitive behaviour in the EU. The CEO, President and/or Chairman of the Board very frequently serve as defendants in EU antitrust cases. As the head of the company often directly and personally engages in the company's anticompetitive behaviour, antitrust internal audit work will probably not receive much support.

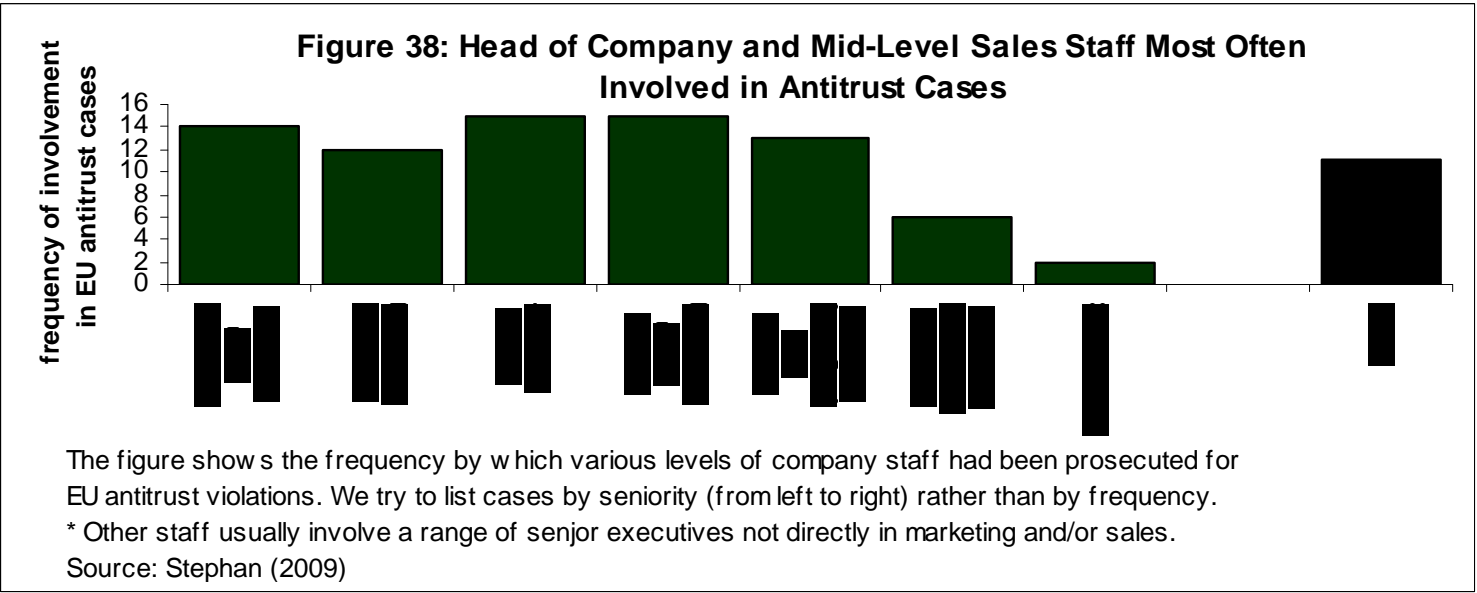

${ }^{149}$ See Andreas Stephan, Hear no Evil, See no Evil: Why Antitrust Compliance Programmes may be Ineffective at Preventing Cartels, CCP WORKING PAPER 09-09, 2009, available online. 
Most authors agree that companies like banks will likely adopt very different antitrust compliance programmes (and thus engage in differing levels of antitrust audits) depending on market and firm-specific factors. Feizi (2011) summarises much of this literature in a model of antitrust auditing which we use to illustrate some of the issues from the literature in the Malaysian context. ${ }^{150}$ Different groups of banks have different costs - and thus different incentives to mark-up prices through anticompetitive practices. High profit banks, according to Feizi's logic and the logic in much of this literature, have either low costs or high rents from anticompetitive behaviour. Using Figure 36 to illustrate this logic, banks like Malayan Bank, CIMB Group, and Public Bank have either low costs or generate profits as the result of collusive rents. ${ }^{151}$ The implication for antitrust internal audit is clear in either case. Highly profitable companies have no incentive to engage in antitrust internal audits. If such profits come from lower costs, bank managers have nothing to fear from a Malaysian Competition Commission investigation. If such profits come from anticompetitive rents, antitrust internal audits would remove these profits, create evidence discoverable by the Competition Commission, and tell managers something they almost certainly know. The Competition Commission will probably not reduce the fine imposed on these companies because they have antitrust audit programmes. ${ }^{152}$ The optimal expenditure on antitrust internal audits for these banks equals zero. ${ }^{153}$

\footnotetext{
${ }^{150}$ Feizi's paper refers to antitrust auditing as investigations conducted by the competition authority. Naturally, from an economic perspective, there is little difference between auditing done by companies themselves and the government (except for incentives to discover wrong doing and how to act on that information). As his paper contains an abstract algebraic model, we formulate some of his discussion in the context of Malaysian banking using profit data. Readers should not assume that Feizi or we suggest any type of impropriety in Malaysian banking. We use these data for

illustrative purposes only. See Mehdi Feizi, Optimal Antitrust Auditing and Cartel Pricing, 2011, available online.

${ }^{151}$ We do not adjust these profits for loan sizes or report profit rates in order to avoid giving the impression that the reader can somehow use the figure to detect collusion in the Malaysian banking sector.

${ }^{152}$ For a discussion in the US context, see Joseph Murphy and William Kolasky, The Role of AntiCartel Compliance Programs in Preventing Cartel Behaviour, 26 ANTITUST 2, 2012, available online.

$\frac{}{153}$ This assumes the Commission does not engage in discretionary enforcement aimed at increasing the final financial impact of penalties and fines (like applying penalties over longer time periods and compounding offences).
} 


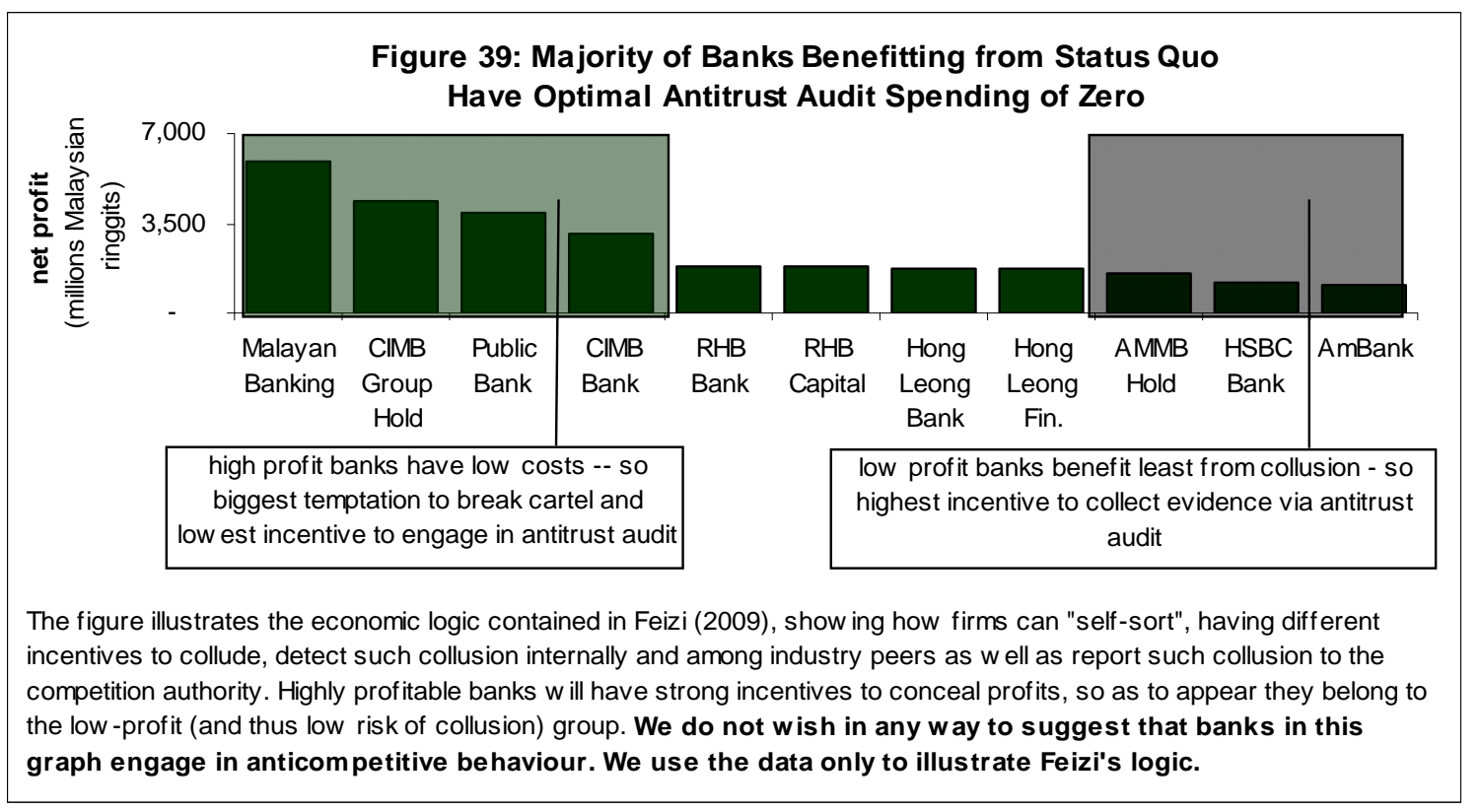

Antitrust audit has a place for low profit firms. If low profits stem from high costs, then internal audit can help identify these high costs and maybe inefficiencies coming from maladroit attempts to engage in anticompetitive behaviour. ${ }^{154}$ If low profits come from relatively unsuccessful anticompetitive behaviour, these companies have the least to lose from whistleblowing to the Malaysian Competition Commission. ${ }^{155}$ The optimal spending on antitrust internal audits for these
firms exceeds zero ringgit.

Yet, the data suggest that any time anticompetitive behaviour allows Malaysia's largest banks to markup operating revenues by more than $10 \%$, they should do it. ${ }^{156}$ A simple numerical example illustrates the point. Imagine RHB Bank, through illegal mark-ups, could earn RM1.2 billion instead of RM1 billion (or a 20\% markup) - with an unchangeable quantity of lending. A $10 \%$ penalty payment would come to RM120 million, with a RM10 million fine increasing that payment to RM130 million. After paying the fine, RHB Bank still earns RM1,070 million - or

\footnotetext{
${ }^{154}$ Collusion and abuse of market power, like any business activity, entail costs and have varying chances of success. Economists might refer to these non-negligible costs as transactions costs. See Antoine Faure-Grimaud, Jean-Jacques Laffont and David Martimort, Transaction Costs of Collusion and Organizational Design, USC CLEO RP C01-17, 2001, available online.

${ }^{155}$ Authors like Aubert et al. provide evidence that internal audit may produce evidence which can help shield colluding bank and other managers in case of competition commission investigation. In this version, such evidence can be brought to the competition authority in order to receive leniency. See Cecile Aubert, Patrick Rey, and William E. Kovacic, The impact of leniency and whistleblowing programs on cartels, 24 INT'L J. OF IND. ORG. 6, 2006.

${ }^{156}$ Operating revenues refer to income after subtracting costs of services provided. If these costs rise as markups increase, then operating revenue may fall. A situation where falling operating profits combines with a $10 \%$ revenue-based fine would clearly have very large and adverse effects on bank profits.
} 
70 million more in revenue. ${ }^{157}$ If we make the unrealistic assumption that their current market power comes as the result of illegal activity, then no amount of compliance spending would help Malaysian banks increase profits. ${ }^{158}$ Figure 40 shows the intuition behind this statement. Malaysia's largest banks earn revenues from interest and fees. Competition Commission penalties of $10 \%$ would reduce these revenues - and reduce profits even faster. Yet, banks may -- at the margin -decide on the extent which they should "set" the level of increased revenue from their anticompetitive behaviour. More anticompetitive behaviour will increase revenues. With a maximum $10 \%$ limit on penalties, Malaysian banks should always set their anticompetitive behaviour (and thus their mark-ups) higher than the Malaysian Competition Commission revenue-tied penalty rate.

Figure 40: With Mark-Ups of $25 \%{ }^{*}$ and Fines of About $15 \%$ of Revenues, Malaysian Banks Will ALWAYS Have Incentive to Act Anticompetitively and Just Pay the Penalties

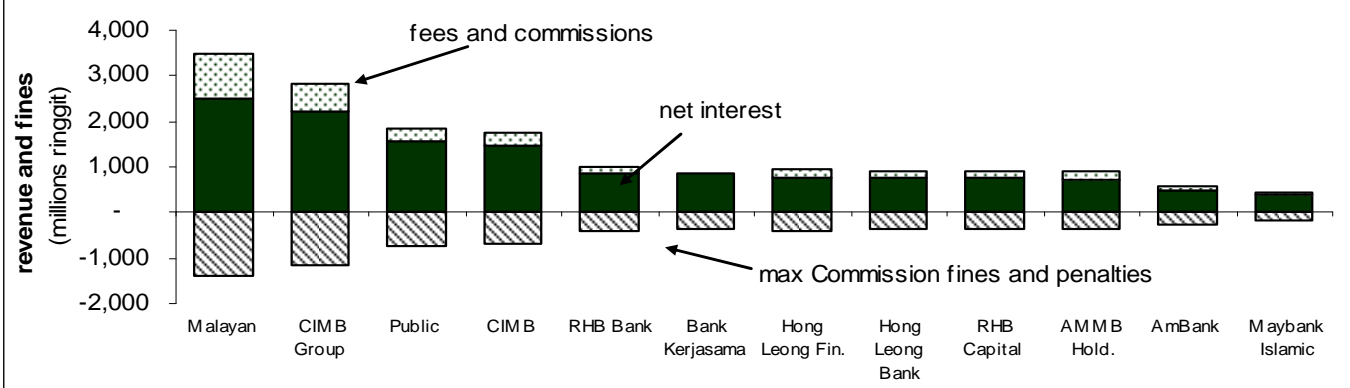

The figure shows the net interest income and income from fees and commissions for a range of Malaysian banks in 2012 (above the horizontal axis). In comparison, we show the maximum fine of $10 \%$ of revenue and a RM10 million fine applied to each bank. The most money the Commission could hope to get in 2012 from any one bank comes to about RM1 billion or about RM2 from the entire industry. We naively assume (for the purposes of this example) that costs do not go up with markups.

* We refer to $25 \%$ markups using the same figure we have used throughout the paper - as an illustration only.

Source: WRDS (2014) with analysis by authors.

Naturally, the amount banks spend on antitrust compliance programmes will depend on other banks’ compliance spending. If all banks, except for CIMB Bank (for example) increase their spending on antitrust compliance, such spending puts CIMB Bank at a disadvantage for three reasons. First, anticompetitive behaviour involving CIMB (again only using the name as an example) detected by another bank (like Malayan) may put CIMB at a disadvantage. Malayan (as part of the cartel) could turn itself in for leniency, channelling the Competition Commission's investigatory and prosecutorial efforts toward CIMB. Second, significant differences in

\footnotetext{
${ }^{157}$ This example depends on a number of factors, like how much increasing prices reduces demand for RHB's loans, if prosecution by the Competition Commission would affect overall demand for borrowing, and the bank's fixed and variable costs (remember that fines come out of bottom line profits and not top line revenues). We avoid these complications in our example, to avoid drawing attention away from our main point. A simple plot of interest income on loans compared with net interest on loans to lending size ratios shows no increase in costs as lending sizes increase. As such, costs should not significantly affect the nature of the argument we make in this section. ${ }^{158}$ We cite several times in this paper studies showing markups in the Malaysian banking sector of about $25 \%$ over marginal costs. We use this figure as a simple heuristic - to think through the effects of the Competition Act's remedies to anticompetitive behaviour in the banking sector. We do not suggest these markups come about exclusively as the result of illegal behaviour.
} 
compliance spending (after adjusting for the size of loan books and other factors) may serve as a red flag to the Competition Commission. When all banks, except CIMB, announce antitrust compliance programmes and show significant spending, CIMB becomes an obvious antitrust audit target. Third, banks spending significant resources on compliance (besides decreasing the potential incidence of anticompetitive behaviour) can also hide their illegal activity better. Simply put, banks with antitrust compliance programmes will better know what evidence needs hiding, tampering, or destroying. ${ }^{159}$ Antitrust compliance programmes and audit can also help encourage changes in illegal behaviour toward less detectable methods of engaging in anticompetitive behaviour. ${ }^{160}$ Banks may play a strategic game in which they do not need to completely hide anticompetitive behaviour. They only need to hide such behaviour better than their peers and rival banks. ${ }^{161}$

The data suggest that Malaysian banks' expenses do not correlate with each other suggesting that banks will unlikely look at each other when deciding on antitrust compliance programmes. Figure 41 shows an example of such spending, namely looking at the extent to which CIMB's other operating expenses change as Public Bank's or Malayan Bank's expenses change. If CIMB changed its spending in response to other banks (like Public or Malayan), the figure would show the difference in such changes around zero. In other words, if CIMB copied changes in other banks' spending, we would see the lines in the figure hover above and close to $0 \%$. Instead, we observe significant positive and negative variation in spending visà-vis these other banks. If other operating expenses could serve as a proxy for compliance and other related spending, we could conclude that CIMB does not simply copy other banks. As shown in the matrix below the figure, we see correlations in spending between groups of banks. CIMB Bank's and CIMB Group's other operating expenses correlate strongly with each other - likely reflecting common markets served and corporate spending policies. Similarly, RHB Bank's and RHB Capital's spending correlate highly with each other. Interestingly, Malayan and Public Bank's other operating expense spending follow each other closely (highly correlates) from 2006 to 2012. If we wanted to look at two banks whose spending might follow each other, we would look at these two banks.

\footnotetext{
${ }^{159}$ We have so little data about evidence tampering (and the destroying of incriminating evidence found during corporate self-assessments and audits) because companies need such data to remain secret. For a recent case of such behaviour, see Melissa Lipman, EU Court Stands Tough Against Tampering In Antitrust Raids, 360LAW, 2012 available online.

${ }^{160}$ The literature has dealt very little with "crime displacement" in antitrust - and even less with the role that compliance audit plays in displacing criminal activity into harder to detect channels. For a discussion of some of these issues, see Christine Parker and Vibeke Nielsen, Eds, EXPLAINING COMPLIANCE: BUSINESS RESPONSES TO REGULATION, 2011.

${ }^{161}$ For a more formal description of the "game" of providing signals and information to markets and regulators about a firm's anticompetitive behaviour, see Mohamed Jellal and Said Souam, A theory of antitrust enforcement game, MPRA WP 38343, 2012, available online.
} 


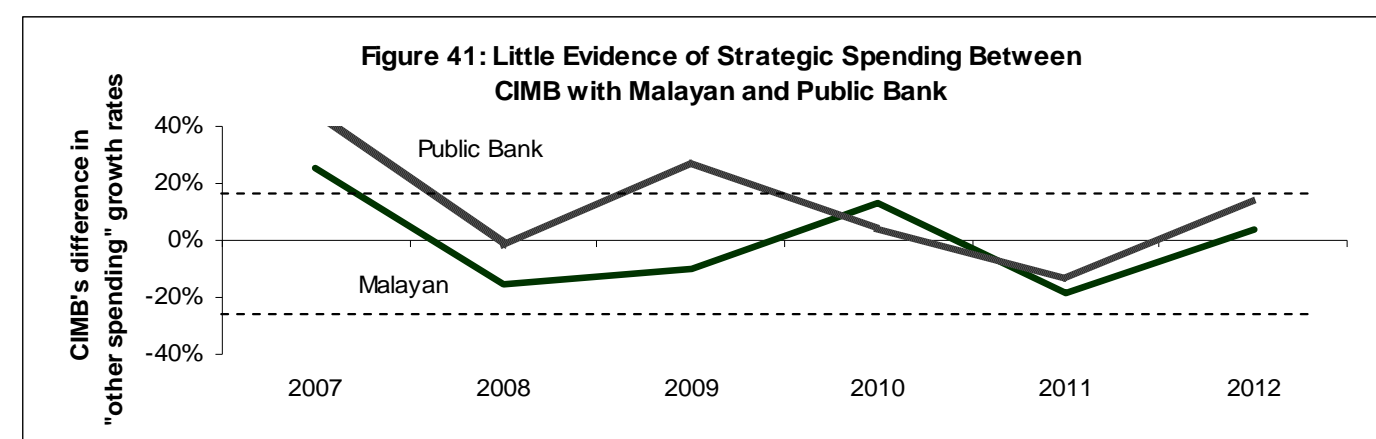

The figure show s the way that CIMB Bank's grow th in spending on "other operating expenses" differs from grow th in spending by Malayan Bank and Public Bank. For example, in 2007, CIMB's operating expenses grew more quickly than Public Bank's or Malayan's. By 2011, both Public and Malayan had faster grow ing operating expenses. The volatility in these lines suggests that $\mathrm{CIMB}$ is not pegging its operating expense grow th rates to match those of Malayan or Public Bank. These data do not remove the effects of common market features which may require banks to change spending together for reasons other than just copying each other. Source: WRDS (2014).

\begin{tabular}{|l|rr|rrrr|r|}
\hline & CIMB Bank & CIMB Group & Malayan & Public Bank & RHB & RHB Capital \\
\hline CIMB Bank & 1.0 & 0.8 & 0.0 & 0.3 & 0.1 & 0.0 \\
CIMB Group & 0.8 & 1.0 & -0.2 & 0.2 & 0.1 & -0.1 \\
Malayan & 0.0 & -0.2 & 1.0 & -0.9 & 0.3 & 0.3 \\
Public Bank & 0.3 & 0.2 & -0.9 & 1.0 & -0.2 & -0.2 \\
\hline RHB & 0.1 & 0.1 & 0.3 & -0.2 & 1.0 & 0.8 \\
\hline RHB Capital & 0.0 & -0.1 & 0.3 & -0.2 & 0.8 & \\
\hline
\end{tabular}

The matrix above shows the correlation in "other operating expenses” from 2006 to 2012 for the banks shown. We highlight correlations greater than 0.75 and do not make any special indications of statistical significance.

So how much money should Malaysian banks spend on antitrust compliance programmes and audit work? We have shown that such spending depends on the amount of money banks would give up by reducing anticompetitive behaviour, the level of such spending by other banks, the extent of Competition Commission oversight (probability of detection), and penalties if/when these banks are investigated by the Competition Commission. Compliance managers should set the level and change of compliance spending to maximise the rents from anticompetitive behaviour while simultaneously minimising the risk of Competition Commission detection. We describe this process in Figure 42 (which non-technical readers should feel free to ignore). Deciding antitrust compliance spending each year - including spending on antitrust internal audit - depends on five factors. First, the change in compliance spending depends on the level of

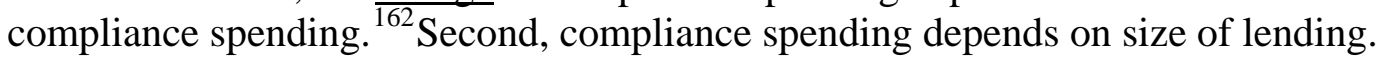
Third, compliance spending by one bank depends strategically on compliance spending by other banks. Fourth, spending naturally depends on the probability of detection and size of potential fines. ${ }^{163}$

\footnotetext{
${ }^{162}$ Such change likely looks like an inverted-U, with banks having no or little compliance speeding up their spending, while big spenders continuing to spend a lot to keep their compliance levels in place.

${ }^{163}$ We spend a great deal of time criticising the penalty structure in the Competition Act - without proposals for its replacement. As we look at the best audit regime given the current rules, we do not focus on improving the current system. For some recent discussions of such optimal fines, see Evgenia Motchenkov, Determination of optimal penalties for antitrust violations in a dynamic setting ,EuRO. J. OF Op. REs. 189, 2008. See also John Connor and Douglas Miller, Determinants of EC Antitrust Fines for Members of Global Cartels, LEAR CONFERENCE PAPER, 2009, available online.
} 


\section{Figure 42: The Maths of Deciding on the Best Level of Annual Antitrust Compliance Spending}

How much should Malaysian banks spend on antitrust compliance and audit work? We previously provided a back-of-the-envelope budget for spending, based on the cost of several popular compliance programme activities (like training, operating whistleblowing programmes, and so forth). But such an estimate ignores the gains from banks engaging in anticompetitive behaviour and using compliance spending to help hide their gains from the Competition Commission. So how much should Malaysian banks spend each year on compliance (and antitrust audit)? What will total spending look like? The change in antitrust compliance and audit spending $(\dot{y})$ will depend on a number of factors, as explained below.

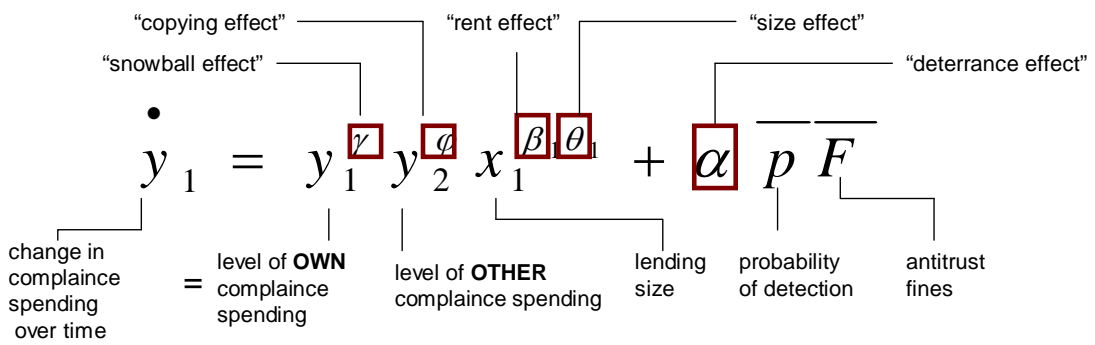

snowball effect $\quad \gamma$ positive

copying effect $\varphi$

positive

size effect $\quad \theta$

positive

rent effect $\quad \beta$

negative

deterrence effect $\quad \alpha$

positive expect positive, as compliance costs increase, banks must spend increasingly more to detect harder to identify risks and maintain current compliance levels.

expect positive, as other banks increase compliance spending, need to increase own spending rises.

as lending sizes increase, need to conduct compliance activities over larger numbers of customers and book sizes. as rents come from mark-ups on quantity, higher value of quantities of lending contribute to anticompetitive rents. positive, as Competition Commission gets better at detecting, investigating and prosecuting anticompetitive behaviour in Malaysia’s banking sector, banks want to spend more.

The best profile of compliance spending depends (unsurprisingly) on the rents banks can earn from anticompetitive behaviour and the way that compliance spending helps safeguard those rents. Readers familiar with math will see immediately that figuring out the change in compliance spending $y$ works out to maximizing the rents from lending $\beta \theta x$. The maximum penalties of $10 \%$ of revenue and RM10 million drive much compliance spending behaviour in the model. 
The figure below shows the way that the optimal compliance spending changes as banks' ability to markup revenues rises. For any markups at all, banks will need to spend a large amount of money (roughly RM1 million). The Competition Commission can remove even tiny rents with very large fines and penalties. As markups increase, banks can expect to keep RM1 million in profits for each extra point of markups. Banks do not want to spend all their rents on the compliance costs of hiding revenue (or eliminating these rents through law-abiding behaviour). Thus additional spending on compliance falls. However, at about $8 \%$ mark ups, banks worry about losing the infra-marginal rents. Namely, they would not be willing to ramp up compliance spending to keep RM3 million in rents. However, by the time these rents come to around RM8 million, banks would spend more money to ensure they do not both lose the rents and suffer from punitive fines which exceed their gains.

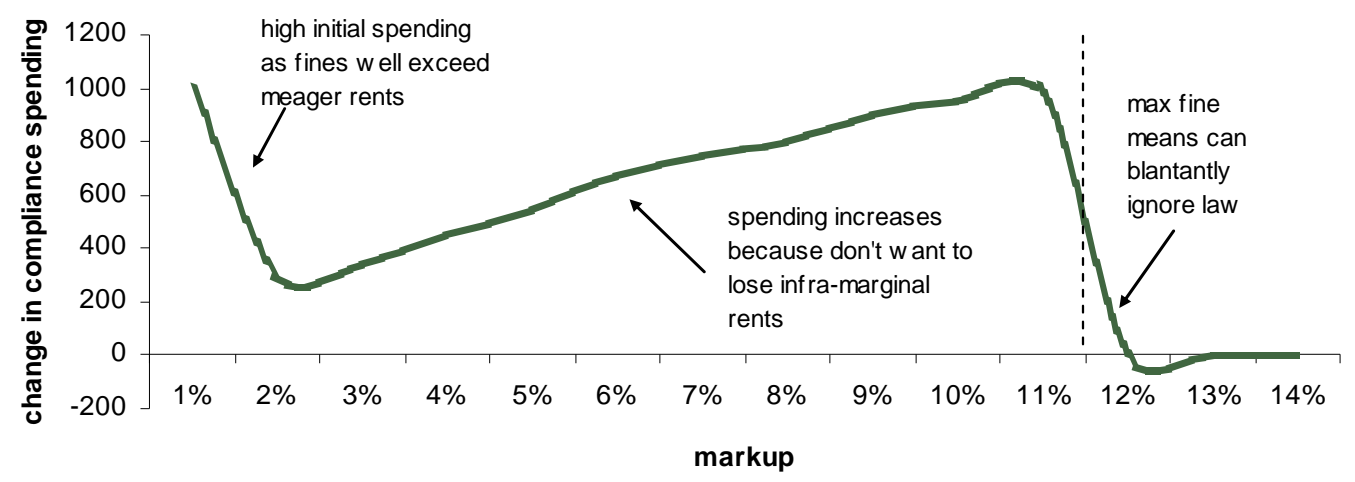

The figure show s the estimated optimal spending on compliance-related activities of a Malaysian bank earning $\$ 1$ billion in gross revenue. We assume maximium revenue-based penalties of 10\%, RM10 in maximum fines, detection probability of $10 \%$ and that compliance spending affects the probability of detection.

This simulation highlights several interesting features about antitrust compliance spending over time when firms react strategically to each others' spending and to Malaysian Competition Commission surveillance. First, firms tend to react the same way over time - seeing benefits from working together. In other words, equilibrium spending on compliance levels out and does not vary over time because banks try to "game" each other's compliance spending. Second, the size of lending does not influence compliance spending behaviour very much. Small banks need to worry about the RM10 fines more than the $10 \%$ revenue-tied penalty. Larger banks worry more about the revenue-tied penalty. In either case, the profile and approximate amount of compliance spending remains the same. Third, the size of compliance spending does not affect the yearly change in such spending. The economics of compliance spending relies on the size of anticompetitive rents and the probability of Competition Commission detection far more than the size of compliance spending. The difference (or change) in compliance spending relates to changes in the probability in detection. As such, changes - rather than levels - of compliance spending drive incentives to invest in antitrust audits. 
What effect would leniency have on incentives to spend on antitrust compliance? The Malaysian Competition Act's leniency provisions (combined with the low maximum fine) would likely further encourage banks to conceal, rather than discover through internal audit, anticompetitive behaviour. Banks providing information to the Competition Commission about their own anticompetitive behaviour may receive "a reduction of up to a maximum of one hundred percent of any penalties which would otherwise have been imposed." ${ }^{\text {"64 }}$ Interestingly, when a leniency programme combines with a fixed fine, the result may solidify rather than destabilise cartels. ${ }^{165}$ In other jurisdictions like the US and EU, leniency programmes help destabilise cartels and provide incentives to report anticompetitive behaviour to local antitrust authorities. Such leniency programmes make sense when the severity of fines and punishments increase as the value of anticompetitive behaviour (and/or harms from such activity) rises.

In Malaysia’s case, leniency programmes - combined with low maximum penalties - encourage companies to collude and hide their collusion. Leniency reduces the expected penalties and fines banks would likely pay - as the possibility always exists to turn themselves or others in to reduce these penalties. ${ }^{166}$ Figure 43 shows the effect of leniency programmes on the expected value of fines paid by cartel members engaging in anticompetitive behaviour. In the figure, we aggregate the value of financial penalties (paid as "infringements" of the Competition Act) and "offences" (such as trying to obstruct the Competition Commission from doing its work). ${ }^{167}$ For a probability of detection at $50 \%$ or less, the value of rents needed to make collusion worthwhile starts at about RM50 million and maxes out at about RM83 million. As the threat of Competition Commission enforcement increases, cartel members need higher levels of compensation to offset potential fines. Even if the value of illegal market power came in at only $1 \%$ of the RM16 billion we previously estimated, the RM160 million in rents would make such collusion economically viable given the likely probability of Competition Commission detection in the near future. Anything banks do to form and hide collusion can only increase their profits - up until they experience an $80 \%$ probability of

\footnotetext{
${ }^{164}$ Competition Act at 41(1).

${ }^{165}$ Feizi for example finds that leniency programmes can destabilise cartels, as individual members have incentives to receive amnesties. However, in the face of Malaysia's relative low fines, leniency actually works against the incentives found in other jurisdictions. See Mehdi Feizi, Optimal Antitrust Auditing and Cartel Pricing, available online.

${ }^{166}$ As an example, imagine Alliance Bank would pay a RM10 million fine for abuse of market power. With a 50\% probability of receiving leniency for turning itself in right before an investigation, the expected value of the fine comes to RM5 million - even if the Commission decided on the full fine of RM10 million.

${ }^{167}$ From an economic point of view, our analysis does not depend on whether banks make payments because of "infringements" or "offences." We assume throughout the paper that financial penalties imposed on anticompetitive behaviour and fines for obstructing the Competition Commission occur together. We could assume banks (financial firms) do not engage in obstruction of justice-style offences without changing the results of our analysis. Indeed, removing these fines from our calculations would make anticompetitive behaviour even more profitable!
} 
detection. At that point, the expected gain in rents could not offset the likely loss from Commission fines.

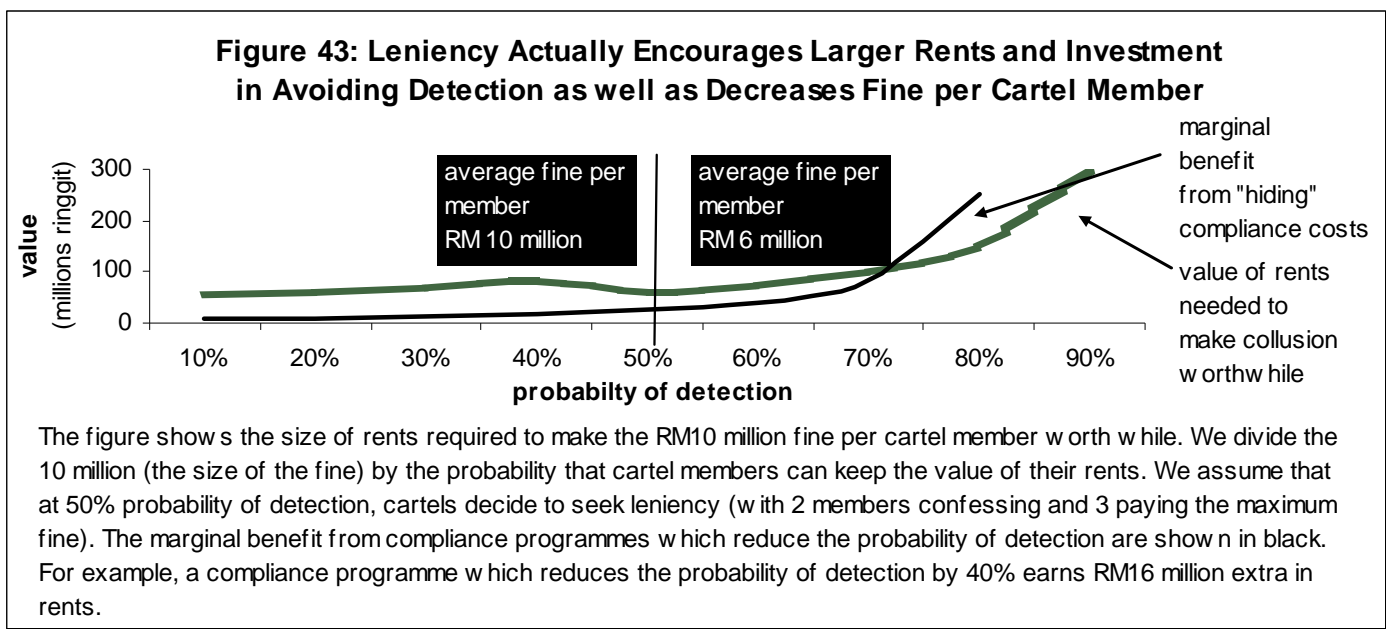

Compliance costs which hide, rather than reduce, anticompetitive behaviour become more profitable as they succeed in reducing the probability of a Competition Commission investigation. For low probabilities of detection, the value of compliance and internal audit work aimed at making collusion harder to spot has little return (as shown by the black line in the figure). ${ }^{168}$ At relatively high probabilities of detection, for programmes which decrease the changes of a Competition Commission investigation by $50 \%$ or more, these programmes will pay off from RM41 million to RM250 million.

Leniency also has the effect of lowering the fine paid per cartel (or collusion group) member. In the figure, we illustrate this point by assuming that, after a $50 \%$ probability of detection, 2 of the 5 group members agree to blow the whistle on the cartel. These 2 members receive leniency and the other 3 members pay the maximum fine of RM10 million. The RM30 million in fines paid to the Competition Commission comes to RM6 per cartel member. Leniency has decreased the expected maximum fine payment by $\mathbf{4 0 \%} .{ }^{169}$ Leniency can also increase collusion, both by reducing the number of disadvantaged parties outside

\footnotetext{
${ }^{168}$ The black line shows the marginal change in the green line (or the value of rents needed to make collusion worthwhile). This marginal change in the black line shows the effect of lowering the probability of detection by $10 \%$ at each probability level of detection. At high probabilities of detection, firms clearly have strong interests in lowering that probability - making the value of rents needed to make collusion worthwhile so much the lower.

${ }^{169}$ Harrington and Chang provide even more dire evidence suggesting that leniency programmes can undermine antitrust enforcement efforts. In their study, they find that when "leniency cases are just as intensive to prosecute and penalties are sufficiently low [certainly the case in Malaysia], then a leniency program is not only ineffective but actually raises the cartel rate because of its deleterious effect on non-leniency enforcement.” See Joseph Harrington and Myong-Hun Chang, Endogenous Antitrust Enforcementin the Presence of a Corporate Leniency Program, 2012, available online.
} 
the cartel, and by encouraging the creation of multiple cartel "ringleaders" who have the clout needed to benefit from these leniency programmes. ${ }^{170}$ Wouldn't private rights of action affect our analysis? In theory, private rights of action - where victims and competitors can sue the members of an illegal agreement or abuser of market power- can increase the penalties for anticompetitive behaviour. ${ }^{171}$ Private action could also increase the probability of detection, as private parties may have stronger profit-based motives to expose anticompetitive behaviour than government actors. ${ }^{172}$ If a competition authority does not have the capacity to vigorously investigate and prosecute anticompetitive behaviour (like seemingly in Malaysia’s case), private action can fill this gap. ${ }^{173}$

Private rights of action probably won't change the economics of antitrust compliance in Malaysia - at least in the short-term. In order for private action to work in Malaysia, potential litigants need court systems which provide "profits" (in the form of awards) for detecting and complaining about anticompetitive behaviour. Yet, such profits seem extremely uncertain. Persons or companies who sue banks engaging in anticompetitive behaviour risk paying long and drawn-out litigation costs if they lose the case. Court-awards would only compensate plaintiffs for their time and expenses; and the burden of proof lies squarely on the plaintiff's shoulders. Even if the bank directly admitted guilt to the Competition Commission, persons bringing competition-related lawsuits would need to show that the financial firm's activity directly led to his or her loss and justify the sum he or she asked the court for. ${ }^{174}$ Thus, litigants looking to profit from suing banks for their anticompetitive behaviour face enormous uncertainty and even the possibility of bankruptcy (if lawyer and other fees exhausts plaintiffs' financial reserves while the case unfolds). .

\footnotetext{
${ }^{170}$ The literature has not settled the question on whether leniency programmes help or hinder a competition authority's work. From an internal audit perspective, leniency programmes create the evidence needed to help qualify for such leniency. On the other hand, leniency reduces the deterrence effect that stiff penalties use to encourage internal audit in the first place. See Georg Clemens and Holger Rau, Do Leniency Policies Facilitate Collusion? Experimental Evidence, DICE WP 130, 2014, available online. See also Maria Bigoni, Sven-Olof Fridolfsson, Chloé Le Coq and Giancarlo Spagnolo, Fines, Leniency and Rewards in Antitrust: An Experiment, CEPR DP7417, 2009.

${ }^{171}$ In evidence from the US, Lande and Davis find that private action resulted in \$30 billion in recoveries and other damages paid for anticompetitive behaviour, in contrast with the roughly $\$ 4.5$ billion in government penalties imposed. See Robert Lande and Joshua Davis, Comparative Deterrence from Private Enforcement and Criminal Enforcement of the U.S. Antitrust Laws, U. OF SAN FRAN. LAW RES. PAP. 2010-17, 2010, available online.

${ }^{172}$ Renda and co-authors amass a large amount of evidence showing that private actions can help competition authorities, both find anticompetitive behaviour and provide strong incentives to contribute evidence for government action. See Andrea Renda, John Peysner, Alan Riley, Barry Rodger, Roger Van Den Bergh, Sonja Keske, Luiss Carli, Roberto Pardolesi, Enrico Camilli and Paolo Caprile, Making antitrust damages actions more effective in the EU: welfare impact and potential scenarios, DG COMP/2006/A3/012, at Table 3, available online.

${ }^{173}$ McAfee and co-authors find a range of cases where private action may effectively replace ineffective government action in enforcing a country's antitrust rules. See Preston McAfee, Hugo M. Mialon, and Sue Mialon, Private v. public antitrust enforcement: A strategic analysis, 92 J. OF PUB. ECON. 10-11, 2008.

${ }^{174}$ For a fuller discussion of issues, see Aimee Goldstein, Elizabeth Morony, James Hosking, and Sarah Keene, Private Antitrust Remedies, In Global Counsel - Competition HANDBOOK, 2010.
} 
Moreover, the data suggest that antitrust cases appearing in Malaysia's courts would not be completely adjudicated based on the merits of the case. Figure 44compares - in scatterplot format - two popular indices of legal and judicial integrity. We show scores for all countries ranked by both the World Bank and Global Integrity. Only one other country (Morocco) scores lower than Malaysia for rule of law and judicial independence. ${ }^{175}$

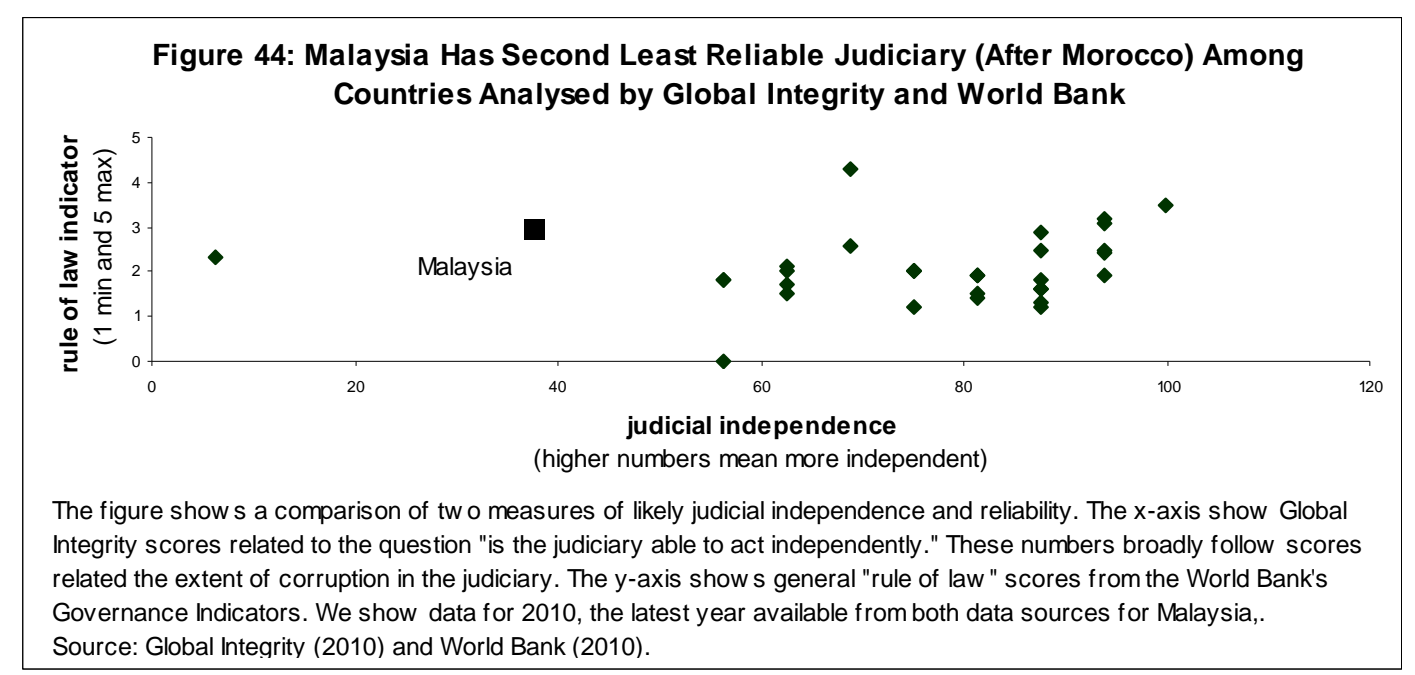

If any group of banks would benefit from antitrust compliance programmes, politically connected banks look like a sub-segment which would benefit from antitrust audits. We previously showed evidence that political connections between banks and/or companies can help facilitate anticompetitive behaviour. We can not know if these connections cause anticompetitive behaviour. However, some evidence suggests that companies with Board staff having high level political connections tend to have statistically significantly higher audit fees. ${ }^{176}$ Gul argues that politically connected companies had significantly higher audit fees because of higher levels of perceived or actual improprieties committed by politically connected firms. When capital controls closed down foreign investor of Malaysian companies, the need to correct for and show fewer misdeeds decreased. As we discussed earlier, politically connected firms in Malaysia have statistically significant differences from other firms in terms of cost of capital, audit costs, and compliance with codes of corporate governance.

\footnotetext{
${ }^{175}$ We have no interest in casting aspersions on Malaysia's judicial sector. Whether true or not, many Malaysian businesses would see the courts as an unreliable means of fighting anticompetitive behaviour in their industry. Such inefficiency may not stem from corruption, as Malaysians themselves consider the courts to have low levels of corruption. See Global Corruption Report 2007, 2007, available online.

${ }^{176}$ See Ferdinand Gul, Auditors' Response to Political Connections and Cronyism in Malaysia, $44 \mathrm{~J}$. of ACCOUNT. RES. 5, 2006.
} 


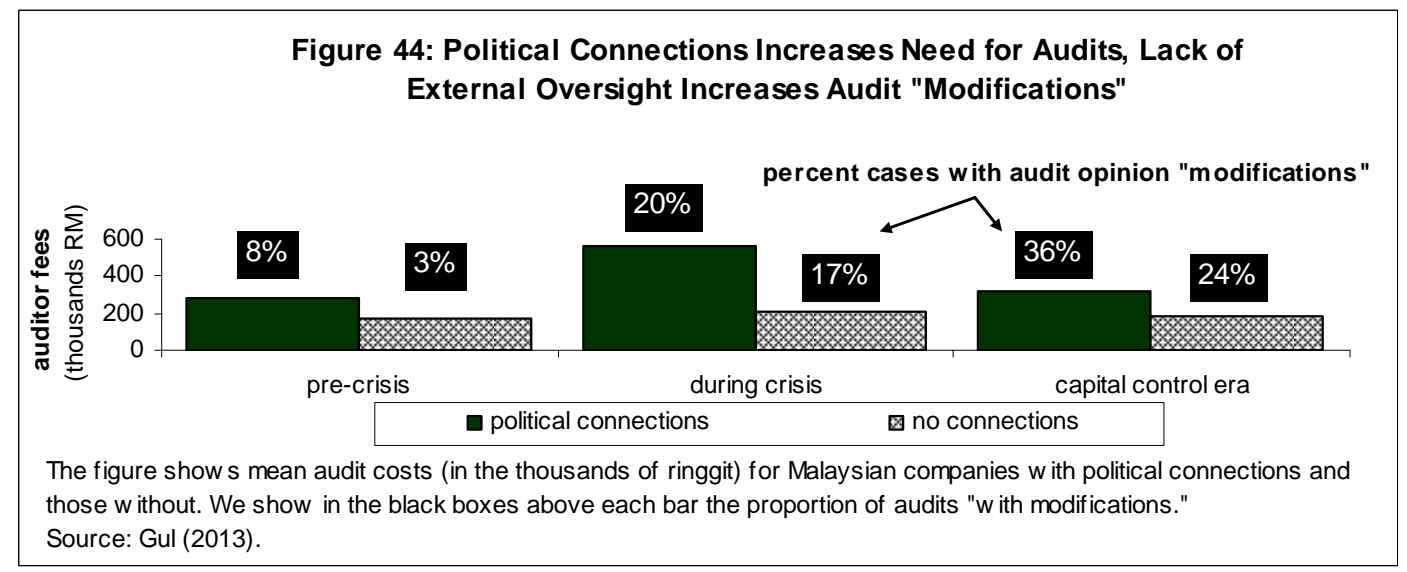

The audit premium in audits of Malaysian politically-connected companies points to a role for antitrust audits in these companies. First, screening companies by the extent of their political connections provides an easy way for the Competition Commission and third-parties (engaging in private action) to detect anticompetitive behaviour. Given this perceived increased probability of anticompetitive behaviour, antitrust audit may help reduce the likelihood of an antitrust prosecution. ${ }^{177}$ Second, if collusion occurs because company staff continue to view such collusion as justified industrial policy, internal audit can help change this mindset. ${ }^{178}$ Particularly for government-linked companies, anticompetitive behaviour may represent a throw-back to the old way of doing things. ${ }^{179}$ Third, more intense antitrust audits may help reassure investors and other partners about the probity of managers of politically controlled banks and companies.

\section{Conclusion}

Based on the economics of compliance, Malaysian financial institutions (particularly banks) should mostly ignore the Competition Act. ${ }^{180}$ The data show that Malaysian banks probably benefit from anticompetitive behaviour - earning about $15 \mathrm{RM}$ billion in rents even after paying the penalties and fines envisioned in the Act. Political and family connections likely facilitate anticompetitive behaviour in corporate Malaysia - if not in the banking sector specifically (though we have no

\footnotetext{
${ }^{177}$ We have argued that antitrust compliance and audit spending should relate to probability of detection by the Competition Commission and fines/penalties. Because political connections (rightly or wrongly) increase this probability, the value of antitrust audit increases significantly.

${ }^{178}$ We do not argue that industrial policy (state policies helping particular sectors) has no place in Malaysia. However, following other countries, such aid should be monitored and (in the words of the OECD) “competitively neutral.” See OECD, Discussion on Corporate Governance and the Principle of Competitive Neutrality for State-Owned Enterprises, 2009, available online.

${ }^{179}$ For the tensions between new competition norms and Malaysia's legacy of industrial policy, see Cassey Lee, Industrial Policy and Competition Policy in Malaysia, PRESENTATION AT THE EAST ASIA COMPETITION POLICY FORUM, 2005, available online.

${ }^{180}$ We make this observation as a way of attracting readers' attention to the incentive structure given by the Competition Act - not as an incitation to commit crime. Strictly following the incentives laid out in the Act may cause Malaysian bank managers to engage in criminally negligent behaviour - a point which takes us outside the bounds of the current paper.
} 
evidence of specific illegal behaviour). Because the Malaysian Competition Commission will likely lack the resources to investigate and prosecute anticompetitive behaviour in Malaysia's banking industry - banks' best response to the Act probably consists of ignoring it. Maximum fines of 10 million ringgit and revenue-based penalties capped at $10 \%$ of world-wide revenues mean that banks have strong incentives to engage in anticompetitive behaviour and just pay the low fines. Because of such perverse incentives, the best compliance programme for banks in Malaysia likely consists of actions which avoid detection rather than stopping anticompetitive behaviour. In theory, provisions in the Competition Act which potentially allow for the disaggregation of competition infractions and drawing out of financial penalties (technically "infringements" in the language of the Act) may allow the Competition Commission to set the optimal financial penalty - defusing many of the points made in this paper. Future cases will test the Commission's resolve to vigorously detect and then sufficiently sanction financial sector firms to ensure appropriate levels of compliance and thus enhancing competition in the sector to the benefit of the consumers of financial services and potentially to the Malaysian economy as a whole.

What does this mean for antitrust compliance and internal audit in Malaysia's banks? First, only a narrow set of banks have financial incentives to engage in antitrust compliance and audit activities. Internal auditors looking to work on antitrust issues should focus on those banks. Second, antitrust audit fees for most banks will probably equal zero. For banks with the economic incentives to engage in antitrust audit, audit fees would be higher than usual. In some cases, these higher fees would go toward finding and removing easy-to-detect anticompetitive activity. In other cases, these fees would help provide assurance that politically connected and family firms do not engage in illegal anticompetitive behaviour. Third, recommendations aimed at decreasing anticompetitive behaviour may run counter to the strong incentives provided by the Competition Act for even non-colluding firms to increase the scope of their anticompetitive behaviour. Fourth, discretionary manoeuvring by the Competition Commission to increase penalties through drawing out infringement periods and disaggregating infringements and imposing maximum allowable civil penalties may make antitrust internal audit more valuable to financial service firms in Malaysia. If the Competition Commission needs to apply maximum fines and take a liberal view as to the period under which anticompetitive behaviour occurred in order to set penalties to their most dissuasive levels, such an enforcement strategy represents a serious risk that internal auditors must take seriously. The result is a challenging antitrust internal audit environment in Malaysia in the years ahead - the real cost of antitrust law to Malaysia's financial services sector! 


\section{Appendix I: Draft Memorandum of Understanding between the Bank Negara and the Competition Commission}

As described in this paper's main text, shared competence for monitoring anticompetitive behaviour between the Competition Commission and the Bank Negara poses several audit risks. Internal auditors on antitrust engagements may miss guidance provided by one of these regulators. They may also under-estimate risk of enforcement (regulatory risk) - given such shared competence. As we also described in the main paper, the Bank Negara may issue antitrust guidelines and controls which the Competition Commission does not view as authoritative - or providing relief from investigation and prosecution even when followed. We offer the following template Memorandum or Understanding between the Bank Negara and the Competition Commission in order to make antitrust internal audit in Malaysia cheaper, easier and more reliable. ${ }^{181}$

\section{Preliminaries}

1. Purpose of this Memorandum. This Memorandum of Understanding shall clarify potentially conflicting, overlapping and inadequately defined shared competence for enforcing provisions from Malaysia's competition law - as enshrined in instruments such as the 2010 Competition Act and 2012 Financial Services Act.

2. Parties to the Memorandum. This Agreement shall cover the Bank Negara and the Competition Commission.

3. Definitions. For the purpose of this Memorandum,

a) anticompetitive behaviour - shall mean any anticompetitive behaviour defined chapters 1 and 2 of the Competition Act or provisions of foreign legislation with impacts on Malaysia’s financial institutions,

b) anticompetitive effects - effects of behaviour prohibited in the Competition Act, and as defined in chapters 1 and 2 ,

c) financial institutions - shall cover any of the institutions defined in the Financial Services Act,

\footnotetext{
${ }^{181}$ Some banks - like association-structure banks and Islamic institutions - may need to follow rules besides the Bank Negara's (and provisions enshrined in the Financial Services Act). We ignore this complexity. The Memorandum we provide here provides the general principles for cooperation which may be extended as needed.
} 


\section{Provisions Governing Surveillance and Investigation}

4. Market Surveillance. As part of its existing market surveillance, the Bank Negara shall take primary responsibility for monitoring banking markets for potential and actual anticompetitive behaviour. Such surveillance does not exclude the Competition Commission from engaging in similar surveillance - using media monitoring, statistical analysis (data-mining) or other methods.

5. Definition of Relevant Market. For the purposes of implementing the Competition Commission's Guidelines on defining markets, the Competition Commission shall consult with the Bank Negara before applying any definition of a Relevant Market.

6. Investigations. Given the complex nature of anticompetitive behaviour in the financial sector, the Bank Negara shall:

a) take the lead on all investigations initiated by the Competition Commission,

b) use any agreements with domestic or foreign law enforcement agencies in obtaining evidence for illegal anticompetitive behaviour defined in the Competition Act, and

c) rely on Competition Commission any staff or other resources as needed.

7. Dealing with the Bank Negara's conflict of interest. If the Competition Commission thinks the Bank Negara does not engage in adequate antitrust surveillance and/or investigation of Financial Institutions, the Commission may using the powers provided by the Competition Act - take the lead in such work directly or (as allowed by law) engage a third-party to engage in such work on the Commission's behalf.

\section{Cooperation on the Application of Antitrust Remedies}

8. Opinion from Bank Negara on Financial Penalties. In deference to the Bank Negara's role and expertise in promoting financial stability, the Competition Commission shall consult with the Bank Negara on fines and penalties applied to Financial Institutions.

9. Penalty Application Schedules. In case extremely unfavourable penalties threaten the liquidity or capitalisation of a Financial Institution (as deemed by the Bank Negara), the Competition Commission may work with the Bank Negara on aspects of applying the penalty (such as timing, payment schedules and so forth) in order to reduce effects on Malaysia's banking and financial markets. 
10. Double jeopardy. In case the Bank Negara creates rules and penalties around practices which may relate to anticompetitive behaviour by Financial Institutions, the Competition Commission shall review these rules and proposed penalties.

11. Action on inadequate regulations. For any rules with penalties the Competition Commission considers inadequate, the Competition Commission will issue a statement on its website advising Financial Institutions that the Competition Commission may impose additional penalties.

12. Penalties Imposable by the Bank Negara. The Bank Negara may, without the consent of the Competition Commission, impose additional penalties on Financial Institutions or their agents, as allowed in the Financial Services Act. Such penalties may include additional fines, revocation of professional or banking licenses and other penalties.

\section{Dealing with potentially anticompetitive rulemaking}

13. Review of anticompetitive Bank Negara rulemaking. The Bank Negara shall, upon request by the Competition Commission, review its own regulations which encourage collusion or other forms of anticompetitive behaviour as defined in the Competition Act.

14. Scope of review. The review, described in article 14, may cover any number of regulations, with the Bank Negara having:

a) up to 120 calendar days to report the results of requests covering more than 3 specific provisions regulations, and

b) up to 30 calendar days to report the results of requests covering 3 or less specific provisions.

15. Action on anticompetitive regulations. Should the Competition Commission decide that a regulation encourages anticompetitive behaviour by Financial Institutions, the Bank Negara shall revise the regulation so as to remove the anticompetitive effect of the regulation (while keeping its public policy objective intact).

\section{Dealing with potentially harmful effects of competition policy on banking stability}

16. Provisions for Private Action. The Bank Negara may, when assessing capital adequacy, liquidity and other prudential measures, consider the effects of potential private litigation on Financial Institutions’ balance sheets.

17. Training about measures to reduce effects of antitrust litigation on Financial

Institutions' balance sheets. The Bank Negara or the Competition Commission may 
provide training to Financial Institution staff on preparing resolution plans, monitoring risks and other work to assist such staff prepare for such potential litigation.

\section{Dealing with anti-trust oversight of self-regulating organisations}

18. Regulation of professionals engaging in banking and financial activity. For any professionals belonging to self-regulating organisations and associations licensed by the Bank Negara, the Bank Negara shall periodically review these organisation's regulations to assess potential for use to restrict competition.

19. Competition Commission’s oversight of Bank Negara's supervision of selfregulating organisations. During its regular surveillance of self-regulating organisations in Malaysia's financial sector, the Competition Commission may censure the Bank Negara publicly for failing to ensure that these self-regulating organisations remove regulations which may have anticompetitive effects.

\section{Foreign cooperation}

20. Co-operation on foreign antitrust cases. In cases where foreign law enforcement agencies request assistance or require mutual legal assistance, the Competition Commission shall represent Malaysia's lead counterpart for these foreign counterparts.

21. Duty to Inform Bank Negara in International Antitrust Cases. The Competition Commission shall copy an assigned representative of the Bank Negara on all communications with foreign competition agencies on matters or cases involving the banking and/or financial sector.

\section{Other provisions}

22. Guidelines and Advice for Banks. The Competition Commission shall release a general toolkit for bank internal auditors by 4 March, 2015. The Bank Negara may follow up with specific guidelines and controls for financial institutions it regulates in close consultation with third parties (like the Malaysian Bankers Association, IMMB) and the Competition Commission.

23. Duty to Inform the Public. Unless preventing by legislation protecting Financial Institutions' privacy, the Competition Commission shall - without consulting the Bank Negara -- post information about antitrust investigations targeted at Financial Institutions. Such information may contain as much, or as little, information as deemed appropriate by the Competition Commission.

24. Whistleblower protection. The Competition Commission shall have the obligation - as defined in the 2010 Whistleblower Protection Act - to protect 
whistleblowers in Financial Institutions providing specifically information about anticompetitive behaviour.

\section{Final Provisions}

25. Additional Members to this Agreement. The Parties may agree, by unanimous consent, to allow other parties to join the Memorandum of Understanding.

26. Execution. This Memorandum of Understanding shall come into effect upon signature of the Parties below, with both Parties placing a copy of this Memorandum on their respective webpages.

Name (for Competition Commission)

date

Name (for Bank Negara)

date 